UNIVERSIDADE DE SÃO PAULO

FACULDADE DE ECONOMIA, ADMINISTRAÇÃO E CONTABILIDADE DEPARTAMENTO DE ADMINISTRAÇÃO PROGRAMA DE PÓS-GRADUAÇÃO EM ADMINISTRAÇÃO

\title{
O VALOR DE RESERVA NAS RENEGOCIAÇÕES \\ - EVIDÊNCIAS EMPÍRICAS DO COMPORTAMENTO OPORTUNISTA -
}

José Roberto Moraes Antiqueira

Orientadora: Profa. Dra. Maria Sylvia Macchione Saes

SÃo PAULO 
Prof. Dr. Adolpho José Melfi

Reitor da Universidade de São Paulo

Profa. Dra. Maria Tereza Leme Fleury

Diretora da Faculdade de Economia, Administração e Contabilidade

Prof. Dr. Eduardo Pinheiro Gondim de Vasconcellos

Chefe do Departamento de Administração

Prof. Dr. Isak Kruglianskas

Coordenador do Programa de Pós-Graduação em Administração 
JOSÉ ROBERTO MORAES ANTIQUEIRA

\section{O VALOR DE RESERVA NAS RENEGOCIAÇÕES - EVIDÊNCIAS EMPÍRICAS DO COMPORTAMENTO OPORTUNISTA -}

Dissertação apresentada ao Departamento de Administração da Faculdade de Economia, Administração e Contabilidade, da Universidade de São Paulo como requisito para a obtenção do título de Mestre em Administração.

Orientadora: Profa. Dra. Maria Sylvia Macchione Saes 
Dissertação defendida e aprovada no Departamento de Administração da Faculdade de Economia, Administração e Contabilidade da Universidade de São Paulo - Programa de Pós-Graduação em Administração, pela seguinte banca examinadora:

Antiqueira, José Roberto Moraes

O valor de reserva nas renegociações: evidências empíricas do comportamento oportunista / José Roberto Moraes Antiqueira. -São Paulo, 2005.

$91 \mathrm{p}$.

Dissertação (Mestrado) - Universidade de São Paulo, 2005

Bibliografia.

1. Negociação (Administração) 2. Investimentos I. Universidade de São Paulo. Faculdade de Economia, Administração e Contabilidade II. Título.

CDD - 658.4052 
À minha maior inspiração, Mariana.

E aos pequenos, Filipe e Karen. 


\section{AGRADECIMENTOS}

À minha orientadora, Professora Sylvia Saes, por me indicar o caminho, sem o qual eu não teria chegado até aqui. E pela paciência, dedicação e amizade.

Ao Professor Sérgio Lazzarini, pela valiosa contribuição na banca de qualificação, e por todo o apoio na construção da pesquisa experimental.

Ao Professor Paulo Furquim, pela valiosa contribuição na banca de qualificação.

Aos colegas Christiane, Frederico, Lúcio e Raquel, pelo auxílio na realização da pesquisa.

Aos alunos da graduação, que cederam seu tempo para participação no experimento.

Aos meus pais, José Carlos e Maria José, pois graças aos seus esforços, hoje podemos colher os frutos.

À minha amada e companheira Mariana, pela confiança irrestrita e amor. Saiba que você está comigo o tempo todo.

Aos meus filhos, Filipe e Karen, porque sempre quem mais aprende sou eu nos momentos em que estamos juntos.

E a todas as pessoas que direta ou indiretamente me ajudaram no desenvolvimento deste trabalho. 


\section{RESUMO}

As negociações apresentam uma zona de possível acordo sempre que o valor de reserva do comprador excede o valor de reserva do vendedor. Howard Raiffa permitiu uma formalização para analisar as negociações, ao representá-las por meio dessa zona de acordo. Neste estudo, propõe-se que esse modelo seja utilizado para análise das renegociações. Para tanto, foram incorporados alguns elementos da Economia dos Custos de Transação já que, entre a negociação e a renegociação, ocorre a deterioração do valor de reserva detido pelo agente que promoveu investimentos em ativos específicos à transação. Os elementos incorporados dessa teoria foram: racionalidade limitada, especificidade de ativos e comportamento oportunista. Em razão da racionalidade limitada, os acordos e contratos são incompletos, porque a previsão de todas as contingências é impossível ou, na melhor das hipóteses, demasiado dispendiosa. Com isso, muitas vezes as partes necessitam promover revisões contratuais, o que demanda o estabelecimento de renegociações. Porém, entre a negociação e a renegociação, sempre que uma das partes investir em ativos específicos à transação, o seu valor de reserva se torna menos favorável, reduzindo o seu poder relativo de negociação. Nessas condições, a contraparte pode agir oportunisticamente, expropriando quase-rendas que antes eram auferidas pelo agente responsável pelos investimentos específicos. Apesar de a Economia dos Custos de Transação adotar o comportamento oportunista como pressuposto comportamental, não afirma que todos os indivíduos agem oportunisticamente o tempo todo. A freqüência das transações e a reputação apresentam-se como restrições a esse comportamento. Além disso, alguns estudiosos entendem que os agentes podem não empregar o comportamento oportunista nas renegociações, já que muitas pessoas procurariam recompensar os indivíduos que no passado lhe fizeram alguma ação favorável. Para examinar que comportamento a contraparte emprega nessa situação, foi realizada uma pesquisa experimental com alunos da Universidade de São Paulo. Os participantes, agrupados em pares, deveriam negociar um determinado bem. A pesquisa envolveu dois estágios: negociação de preços para o primeiro ano, em que as partes tinham seus valores de reserva originais, pois os investimentos específicos ainda não haviam sido realizados; e negociação de preços para o segundo ano. Neste último estágio, denominado de renegociação, o valor de reserva de uma das partes havia se deteriorado, em razão dos investimentos específicos. A comparação entre os resultados da negociação e da renegociação permitiu constatar que alguns agentes empregaram o comportamento oportunista. Em 62,7\% dos casos, houve alguma redução de preços entre a negociação e a renegociação. Em alguns casos, a pilhagem na renegociação foi tão intensa que o agente expropriado obteve um valor menor do que aquele proporcionado pelo valor de reserva original. A pesquisa revelou que o comportamento oportunista foi mais freqüente e ocorreu com maior intensidade com alunos que já se conheciam. Por fim, o comportamento oportunista não apresentou associações significativas com idade e sexo dos participantes, com o ano de ingresso na faculdade ou com a postura competitiva na primeira etapa das negociações. 


\begin{abstract}
A possible agreement zone appears in negotiations whenever the buyer's reservation value exceeds that of the seller. Howard Raiffa brought a fairly structured manner to the analysis of negotiations by representing them through this agreement zone. Our intention is for this model to be used in the analysis of renegotiations. To that end, some elements of Transaction Cost Economics (TCE) have been incorporated inasmuch as deterioration occurs, between the negotiation and the renegotiation, in the reservation value detained by the agent that made investments in transaction specific assets. The elements incorporated from the TCE were the following: limited rationality, asset specificity and opportunistic behavior. Limited rationality leads to incomplete agreements and contracts because forecasting all contingencies is impossible or, in the best of hypotheses, too expensive. For that reason, the parties often need to carry out contractual revisions, which require setting up renegotiations. Nevertheless, whenever one of the parties invests in transaction-specific assets between the negotiation and the renegotiation, its reservation value becomes less favorable thus reducing its relative negotiation power. Under those conditions, a counterpart can have an opportunistic behavior, thus expropriating the quasi rents that were before received by the agent responsible for the specific investments. Although TCE adopts opportunistic behavior as the behavior premise, it does not state that all individuals act opportunistically all of the time. Both the frequency of the transactions and the reputation limit this kind of behavior. Besides, some scholars understand that agents might not act opportunistically in negotiations, insofar as many people would seek to reward individuals who took a favorable action toward them. In order to examine which behavior becomes active in the counterpart in this situation, an experimental research was accomplished with students from the University of Sao Paulo, Brazil. Paired participants were instructed to negotiate a specific asset. The research involved two stages: price negotiation for the first year, in which the parties had their original reservation values, since specific investments had not yet been made; and price negotiation for the second year. In this last stage, called renegotiation, the reservation value of one of the parties had deteriorated due to specific investments. The compared outcomes of the negotiation and renegotiation allowed verifying that some agents did act opportunistically. In $62.7 \%$ of the cases there was a price reduction between the negotiation and the renegotiation. In some cases, hold-up in the renegotiation was so intense that the expropriated agent obtained a lower value than that of the original reservation value. The research revealed that opportunistic behavior was more frequent and more intense among students who already knew each other. Final conclusion was that the opportunistic behavior was not significantly associated with participants' age or gender, the year of college entrance or competitive stand in the first round of negotiations.
\end{abstract}




\section{SUMÁRIO}

1 INTRODUÇÃ

2 NEGOCIAÇÃO: CONCEITO E PERSPECTIVAS DE ESTUDO ............................ 7

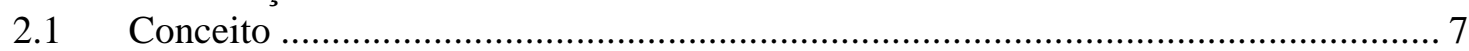

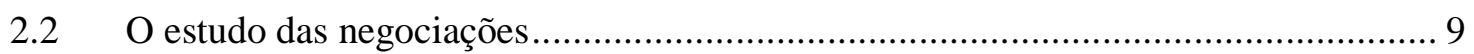

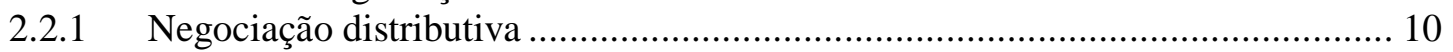

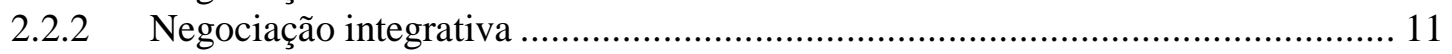

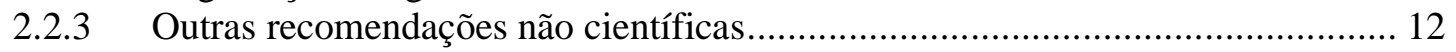

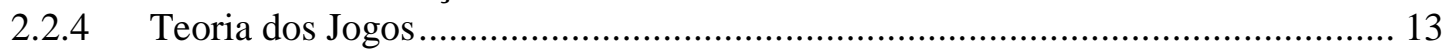

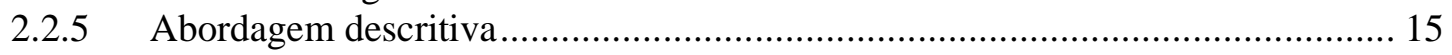

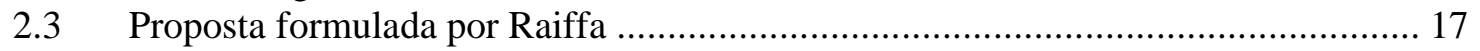

3 VALOR DE RESERVA: O MODELO PROPOSTO POR RAIFFA ......................... 18

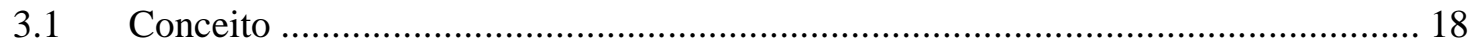

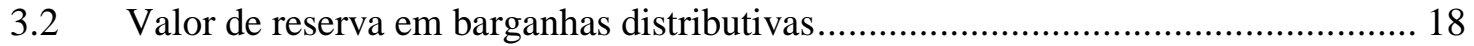

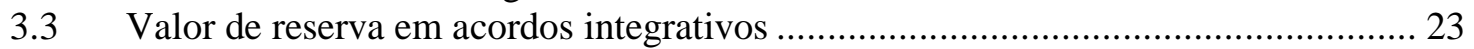

3.4 Limitações na utilização do modelo ................................................................... 26

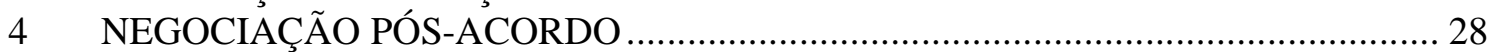

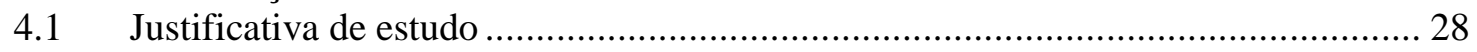

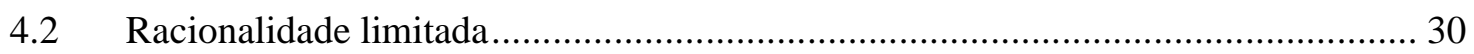

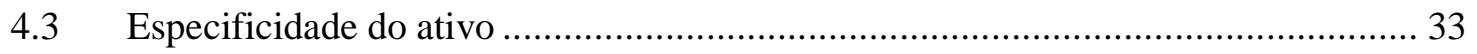

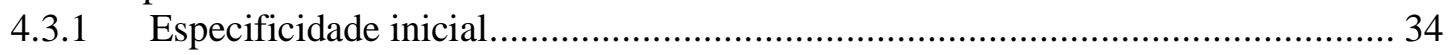

4.3.2 Especificidade decorrente dos investimentos promovidos .............................. 36

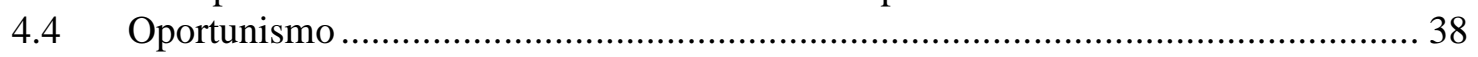

4.5 Restrições ao comportamento oportunista ........................................................ 41

4.5.1 Sanções contratuais, freqüência das transações e reputação................................ 42

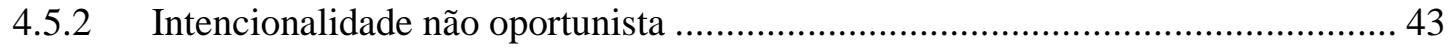

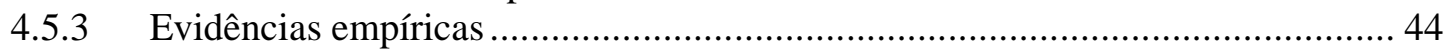

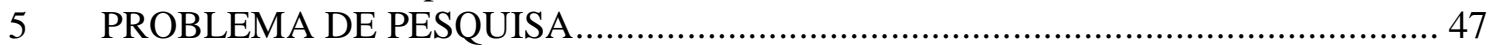

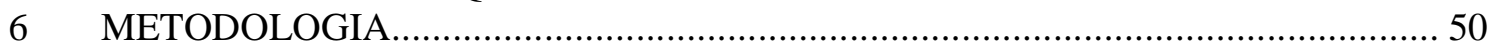

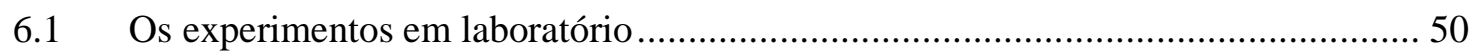

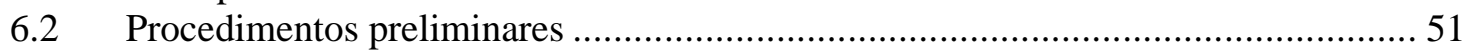

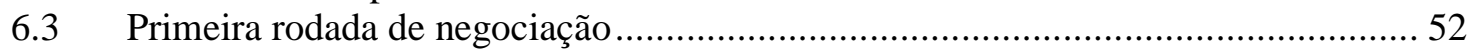

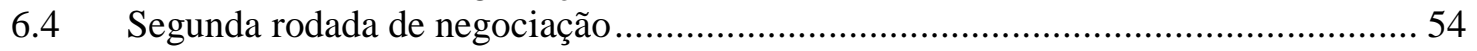

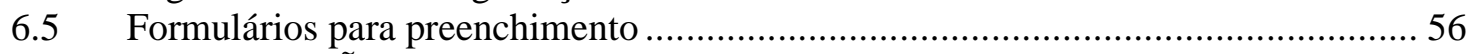

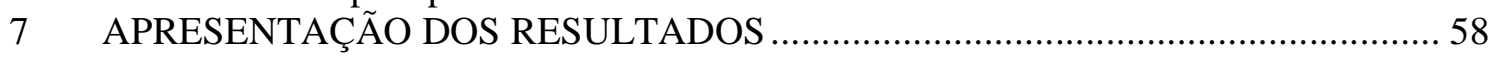

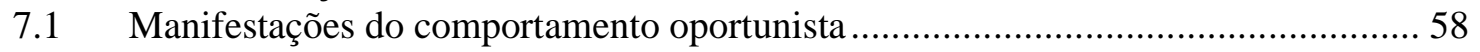

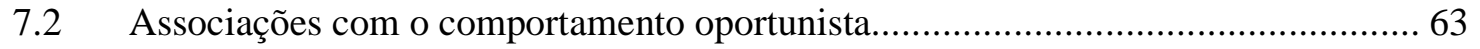

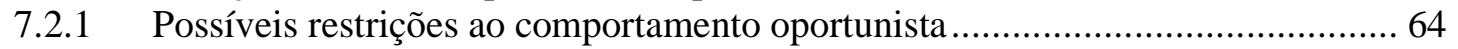

7.2.2 Associações do comportamento oportunista com outras variáveis ........................ 66

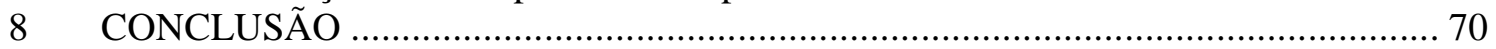

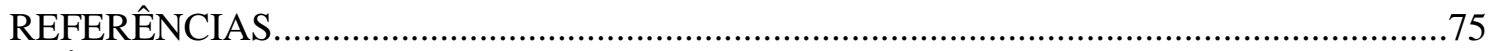

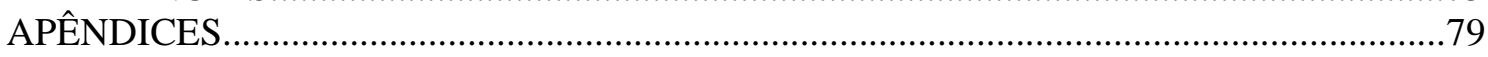




\section{INTRODUÇÃO}

As negociações sempre estiveram presentes no cotidiano das pessoas. Apesar disso, as soluções obtidas nessas interações nem sempre foram as mais favoráveis. Ainda que em determinado processo de negociação seja plenamente viável a consecução de um acordo com resultados positivos para todos os envolvidos, muitas vezes as pessoas não chegam ao consenso. Por outro lado, mesmo quando o acordo é obtido, os termos finais podem ser considerados injustos por alguma das partes. Outro problema recorrente diz respeito às oportunidades não percebidas ou abandonadas sobre a mesa de negociações: nesse caso, todos os envolvidos apuram uma recompensa inferior àquela que seria possível conquistarem. Em razão dessas dificuldades, e entendendo que existe a necessidade de adotar estratégias para alcançar resultados mais eficientes, muitos autores se propuseram a estudar o tema e apresentar prescrições aos negociadores. Alguns deles recomendam técnicas para que o negociador amplie sua participação nas recompensas em disputa ou, pelo menos, evite um resultado final desfavorável. Acreditando na possibilidade de uma postura mais colaborativa, outros autores propõem métodos para que se construa um acordo em que todos os envolvidos na negociação maximizem os seus ganhos.

A rigor, pode-se dizer que os estudos de negociação têm uma finalidade normativa, já que visam propor estratégias e táticas para obtenção de melhores resultados. Esses estudos, no entanto, podem partir de diferentes bases do conhecimento, inclusive as não científicas. ${ }^{1}$ Entre os conhecimentos científicos que fornecem análises com potencial prescritivo, destaca-se a Teoria dos Jogos. Outra fonte de estudos para os analistas das negociações é a abordagem descritiva, em que o pesquisador se dedica a observar como os negociadores de fato se comportam. A análise dos sujeitos reais, ainda que em laboratórios, pode fornecer padrões e erros comumente incorridos. Todas essas perspectivas, contudo, ainda não esgotam os estudos das negociações.

\footnotetext{
${ }^{1}$ Mesmo reconhecendo que parte da literatura didática ou voltada para executivos envolve assertivas não refutáveis, optou-se pela inclusão de alguns desses escritos neste trabalho, já que neles existem importantes conceitos, amplamente utilizados pelos analistas de negociação. A fim de que o rigor científico não seja prejudicado, entretanto, é destacado no próprio texto quando os estudos não resistem ao processo de refutação científica.
} 
Utilizando-se dos conceitos desenvolvidos pelas abordagens citadas, e assumindo que a melhor alternativa à negociação do acordo (MAANA) ${ }^{2}$ constitui o valor de reserva (VR) de cada uma das partes envolvidas na negociação, Raiffa (1982) propôs a análise das negociações por meio da representação da zona de possível acordo. Desde então, esse modelo é amplamente utilizado nos livros sobre negociação.

No relacionamento entre as empresas, entretanto, as negociações não necessariamente cessam após o fechamento dos acordos e a eventual celebração dos contratos, já que os acordos muitas vezes têm efeitos continuados. Destarte, o objetivo deste trabalho é trazer uma contribuição para o mundo das negociações, ao expandir a aplicação do modelo proposto por Raiffa para o processo de renegociação. Para explicar o porquê das renegociações e analisálas sob a ótica do VR, são incorporados alguns conceitos utilizados pela Economia dos Custos de Transação, principalmente na obra de Williamson (1987; 1993; 1996), Klein et al (1978) e Klein (1996). Os termos emprestados dessa teoria são: racionalidade limitada; especificidade de ativos; e oportunismo.

Em face da racionalidade limitada, os acordos são necessariamente incompletos, o que implica o inevitável surgimento de contingências. Dessa forma, torna-se necessário que as partes estabeleçam renegociações para promover as necessárias revisões nos acordos ou contratos. Assim como em qualquer outra negociação, é fundamental o conhecimento do próprio VR e a avaliação probabilística do VR da contraparte. Contudo, se a transação exigir que o negociador promova investimentos em ativos específicos, o seu valor de reserva nas renegociações se torna menos atrativo, motivo pelo qual esse negociador pode ficar exposto ao comportamento oportunista da contraparte.

Com a deterioração do VR de um dos lados, o outro negociador tem um acréscimo no poder relativo de barganha, sendo possível expropriar ganhos antes auferidos pelo agente responsável pelos investimentos específicos. Porém, apesar de adotar o pressuposto do oportunismo, a própria ECT admite que nem sempre os agentes irão se comportar oportunisticamente nessas situações (Williamson, 1987, p. 64). Além das punições e recompensas associadas às diferentes condutas, a própria intencionalidade pessoal também

\footnotetext{
${ }^{2}$ Por "melhor alternativa à negociação do acordo", entende-se a opção externa à negociação que apresenta uma recompensa mais favorável ao negociador. Em outras palavras, MAANA significa o que o negociador tem em mãos caso não queira negociar ou se as conversações com a contraparte fracassarem.
} 
pode restringir esse comportamento, já que existem evidências de que as pessoas buscam recompensar aqueles que no passado lhes presentearam ou agiram favoravelmente (FEHR; GÄCHTER, 2000, p. 159). Por esse motivo, os problemas enfrentados pelo negociador não se limitam às perdas eventualmente apuradas em decorrência do comportamento oportunista nas transações que envolvam especificidade de ativos, mas também envolvem as oportunidades perdidas ao não concretizar acordos em que o outro lado não agiria oportunisticamente.

Tendo isso em conta e considerando o caráter normativo dos estudos de negociação, o oportunismo, diferentemente da proposição formulada pela Economia dos Custos de Transação, não é assumido neste trabalho como um pressuposto comportamental dos agentes. Pelo contrário, a ocorrência ou não do comportamento oportunista é justamente o que se pretende testar. Entende-se que essa questão é de fundamental importância para: os analistas de negociação interessados na análise das barganhas distributivas e integrativas; e, principalmente, para os agentes que necessitem promover investimentos não triviais em investimentos específicos. Dessa maneira, surgem naturalmente duas hipóteses concorrentes: os agentes respondem a tais situações de maneira oportunista; ou, alternativamente, os agentes agem de maneira colaborativa, não oportunista.

Portanto, o objetivo enfrentado neste trabalho é duplo:

a) Integrar conceitos da Economia dos Custos de Transação ao leque de estudos dos analistas da negociação e, com isso, estender a aplicação do VR como referencial para a análise das renegociações;

b) Identificar se os agentes adotam um comportamento oportunista ou agem de maneira colaborativa nas renegociações dos acordos e contratos, quando o VR da contraparte se torna menos favorável em razão dos investimentos específicos por ela promovidos.

Do último objetivo, extrai-se o problema de pesquisa proposto neste trabalho:

\footnotetext{
“Que comportamento - oportunista ou não oportunista - os agentes manifestam nas renegociações quando seu poder relativo de negociação aumenta em razão dos investimentos específicos promovidos pela contraparte?"
} 
Para responder ao problema apresentado, foi realizada neste trabalho uma negociação experimental com alunos do curso de graduação em Administração, oferecido pela Universidade de São Paulo. O experimento agrupou os alunos em pares - investidor e comprador-e envolveu dois estágios:

a) Investimento em ativos específicos e negociação - as partes negociam o preço pelo qual determinado bem será transacionado no primeiro ano. No entanto, para que a transação seja concretizada, um dos alunos - investidor - precisa promover investimentos em ativos específicos à transação. Os participantes têm conhecimento do seu VR e do VR da contraparte. Se não houver acordo, pressupõe-se que o investidor não investiu em ativos específicos e ambos recebem o ganho proporcionado pelo seu VR;

b) Renegociação - as partes negociam o preço pelo qual esse mesmo bem será transacionado no segundo ano. Porém, existe redução no VR do investidor, em face dos investimentos em ativos específicos. Além disso, há introdução de informação assimétrica, já que o novo VR do comprador não é revelado ao investidor. Antes que as conversações se iniciem, o comprador recebe um envelope confidencial informando que o seu VR permanece idêntico ao do estágio precedente.

A comparação entre os preços praticados no primeiro e no segundo estágio permite constatar se o comprador empregou um comportamento oportunista. Além da resposta ao problema esposado, a pesquisa teve por proposta, no caso de haver constatação de comportamento oportunista em alguns agentes, verificar se existem associações entre esse comportamento e algumas características dos negociadores, tais como sexo, idade, conhecimento prévio dos participantes e outras. 


\section{NEGOCIAÇÃO: CONCEITO E PERSPECTIVAS DE ESTUDO}

\subsection{Conceito}

Para que o processo de renegociação possa ser analisado, torna-se necessário preliminarmente discutir o que se entende por negociação. Com base nisso, este capítulo apresenta algumas definições sobre o que caracteriza uma negociação, bem como demonstra, na seção 2.2, como o assunto tem sido estudado nos meios acadêmicos, principalmente nos cursos de graduação e livros dedicados à Administração. Este capítulo ainda introduz, na seção 2.3, a proposta de formalização das negociações sugerida por Raiffa, tema que é aprofundado no capítulo 3.

A palavra negociação tem uma abrangência muito mais ampla do que a inicialmente percebida. Até mesmo a definição apresentada por alguns autores parece limitar o real significado do termo. Nesse sentido, talvez simplificando excessivamente a questão, Cohen (1980, p. 13), afirma que "A negociação é um campo de conhecimento e empenho que visa à conquista de pessoas de quem se deseja alguma coisa. É só isso.” Percebe-se que o autor conceitua o termo como um processo em que alguém busca exercer influência ou obter alguma vantagem de outra pessoa.

Embora sem apresentar uma definição formal, Raiffa (1982, p. 7) refere-se à negociação como uma alternativa às tradições, regras, tribunais e mercados (por meio das leis de oferta e demanda) na resolução de disputas. Contudo, além do emprego na solução de um problema ou disputa entre partes, a negociação também é utilizada para a criação de "[...] algo novo que nenhuma das partes poderia fazer por si só [...]” (LEWICKI et al, 2002, p. 18).

Adotando um conceito mais abrangente, e dando ênfase aos lados envolvidos, situa-se Mello (2003, p. 25), para quem "[...] negociação é um processo social utilizado para fazer acordos e resolver ou evitar conflitos." Nessa mesma direção, Sebenius (1992, p. 27) afirma que as pessoas negociam quando satisfazem mais seus interesses com alguma ação decidida conjuntamente do que conseguiriam fazê-lo de outra maneira. 
Essa tensão entre adotar uma definição estrita ou mais abrangente é evitada por Fisher et al (1994, p. 15) ao recorrerem às duas formas possíveis: “A negociação é um meio básico de conseguir o que se quer de outrem. É uma comunicação bidirecional concebida para chegar a um acordo, quando você e o outro lado têm alguns interesses em comum e outros opostos." É preciso salientar que a negociação não é algo necessariamente bidirecional, podendo envolver uma comunicação multilateral, com mais agentes envolvidos. Conforme Raiffa (1982, p. 11) descreve, não somente pode haver mais de duas partes envolvidas numa determinada disputa, como também existem situações em que as partes não estão bem identificadas.

Embora este trabalho não tenha por pretensão firmar uma nova definição para o termo, é importante destacar, entre os elementos mencionados pelos autores, a concepção de que negociação envolve um processo no qual as partes se interagem, e assim procedem motivadas por interesse. Sobre isso, apesar de Watkins $(2004$, p. 9) entender que negociação consiste na busca do acordo por meio do diálogo, propõe-se que a interação das partes não é algo necessariamente verbal. Corroborando esse entendimento, Andrade et al (2004, p. 54) afirmam que a negociação não se resume à discussão; envolve, porém, uma série de ações a fim de favorecer as partes na obtenção de um acordo.

A negociação pode inclusive ser tácita, por meio de sinais, de movimentos e contramovimentos, tal como o comportamento de empresas que concorrem num mesmo nicho de mercado, ao praticar alterações de preços e estabelecer ou cessar promoções. As negociações envolvem mesmo a sinalização não intencional, emitida pelas partes. Nesse sentido, pode-se citar Brams (2003, p. xxii), para quem negociação refere-se às trocas efetuadas pelas partes com o objetivo de reconciliar diferenças e estabelecer o acordo, incluindo nessas trocas desde a conversa franca sobre termos do acordo até a descarada ameaça à contraparte por meio de alguma ação indireta.

Independentemente do conceito utilizado, porém, os autores convergem no entendimento de que a negociação não é algo restrito a especialistas. Lewicki et al (2002, p. 17) afirmam que “A negociação não é um processo reservado apenas ao diplomata habilidoso, ao melhor vendedor ou a um ótimo advogado sindicalista: é algo que todos fazem, quase que diariamente." Assim, as negociações são freqüentes no cotidiano das pessoas. Outro aspecto comum na literatura é o reconhecimento de que a negociação não ocorre somente nas interações entre pessoas, já que as famílias, as organizações econômicas, as nações e os 
grupos de interesse formais ou informais recorrem às negociações nas múltiplas interações a que estão expostos.

Ao considerar esses outros agentes, entretanto, surge uma questão que nem sempre tem sido explicitada pelos autores: o fato de existirem negociações mesmo após a celebração dos acordos, principalmente quando os agentes envolvidos são organizações econômicas.

\subsection{O estudo das negociações}

Apesar de Sebenius (1992, p. 18) afirmar que as análises de negociação pretendem construir uma teoria prescritiva, não existe uma teoria formal para o estudo das negociações. Raiffa (1982, p. 7) também escreveu sobre a "a arte e a ciência da negociação", mas o próprio autor confessou utilizar o termo ciência sem qualquer rigor, almejando apenas referir-se a uma análise sistemática para resolver problemas. O autor ainda admite que mesmo o termo "análise sistemática" parece um pouco vago. Do mesmo modo, Raiffa considera como evasivo o termo "arte", incluindo nele as habilidades interpessoais, a capacidade de convencer e ser convencido, a capacidade de empregar um amplo leque de astúcias e regateios, e a sabedoria de saber quando e como usá-lo.

Mesmo não constituindo uma teoria, as análises de negociação compreendem um vasto campo de estudo, cujas contribuições apresentam cada vez mais um caráter interdisciplinar. A economia, o direito, a psicologia e outras disciplinas têm oferecido importantes subsídios, favorecendo inclusive o estudo de temas mais específicos, como a arbitragem em negociações ou a negociação internacional.

De acordo com Brams (2003, p. xxi), os processos de negociação e seus resultados são estudados nas ciências políticas, na economia, na psicologia e na sociologia. Ainda segundo o autor, devido à valorização das habilidades do negociador, os cursos de negociação são freqüentes em escolas de negócios e de direito. O interesse pela matéria ainda induziu a publicação de uma série de livros e artigos sobre negociação. 
Ainda que a amplitude e complexidade do campo de estudo praticamente inviabilizem uma classificação de todas as correntes que se dedicam à análise das negociações, é construído neste capítulo um pequeno panorama de contribuições da literatura, sem qualquer pretensão de esgotar o tema, mas somente apresentar uma visão geral de algumas abordagens, conceitos e técnicas.

\subsubsection{Negociação distributiva}

A negociação distributiva, também chamada de barganha distributiva ou ganha-perde, é aquela em que o ganho total é constante. Cabe às partes somente dividir o que está sobre a mesa. Raiffa (2002, p. 97) designa por barganha distributiva aquela negociação, ou aquelas partes de uma negociação mais ampla, que tenha por objetivo a divisão de um único bem. Logo, existem duas condições a serem atendidas: existência de uma só questão na mesa de negociações e partes com interesses opostos.

Reconhecendo esse tipo de negociação, diversos autores apresentam recomendações para que o negociador chegue a um melhor acordo individual à custa do outro lado. Outros autores não aconselham a utilização das chamadas táticas duras, mas explicam como elas funcionam a fim de que as pessoas estejam preparadas para enfrentá-las quando se confrontarem com um negociador competitivo. Segundo Lewicki et al (2002, p. 76),

\footnotetext{
Há duas razões pelas quais todo negociador deveria estar familiarizado com a barganha distributiva. Primeiro, algumas situações independentes que os negociadores enfrentam são distributivas e, para se ter um bom desempenho nessas situações, os negociadores precisam entender como funcionam. Segundo, como muitas pessoas usam, quase que exclusivamente, estratégias e táticas de barganha distributiva, todos os negociadores acreditam ser importante saber como neutralizar seus efeitos.
}

Entre as táticas que visam tirar proveito do outro lado, encontram-se:

a) Autoridade limitada - o negociador conduz o processo - ou parte do processo - de negociação obtendo concessões do outro lado, mas invoca a falta de autoridade quando o outro lado espera dele alguma concessão (COHEN, 1980, p. 126-128);

b) Mordida ou dentada - quando todas as questões parecem solucionadas e o acordo é iminente, pede-se uma concessão pequena em um item que não foi previamente discutido (LEWICKI et al, 2002, p. 109); 
c) Mocinho e bandido - dois indivíduos se apresentam para a negociação com a contraparte, sendo que um deles adota uma postura inflexível ou ríspida, enquanto o outro, flexível ou carismático, "negocia" com o primeiro, aparentemente defendendo os interesses do outro lado (Ibid., p. 107);

d) Trabalho na neve - o negociador expõe muitas informações à outra parte, de tal sorte que esta tem dificuldades em determinar quais são os fatos reais ou importantes e quais são incluídos somente como distrações (Ibid., p. 113).

Essas prescrições, entretanto, enfrentam um óbice: provavelmente o negociador não produzirá um resultado mais favorável se o outro lado identificar a técnica utilizada ou estiver preparado para tal situação. Além disso, essas técnicas ou prescrições não podem ser submetidas a processos de refutação, motivo pelo qual não constituem conhecimento científico.

\subsubsection{Negociação integrativa}

Quando existem opções de as partes conciliarem interesses de forma a ampliar o ganho de todos os envolvidos, diz-se que a negociação é integrativa. De acordo com Sebenius (1992, p. 29), o ganho conjunto no acordo pode ser majorado se as partes souberem explorar: economias de escala; interesses comuns; e diferenças em questões de sensibilidade a risco, liquidez, prazos, acesso a mercados, etc. Conforme apontam Lewicki et al (2002, p. 6), em muitas negociações todas as partes podem ser vencedoras. Por conta disso, Sebenius (1992, p. 28) afirma que muitos analistas procuram criar valor oferecendo sugestões para explorar o comportamento cooperativo.

Entre os estudos voltados para esse tipo de negociação, destaca-se o método denominado “negociação baseada em princípios" ou "negociação dos méritos", desenvolvido pelo Projeto de Negociação de Harvard. Conforme Fisher et al (1994, p. 28), a negociação baseada em princípios apresenta-se como alternativa à barganha de posições, em que cada lado busca obter o melhor para si à custa do outro. Esse método, apresentado por Fisher et al (1994, p. 28-29) no livro "Como chegar ao sim", pode ser resumido em quatro recomendações fundamentais:

- Separar as pessoas do problema; 
- $\quad$ Concentrar-se nos interesses, e não nas posições;

- $\quad$ Criar opções antes de decidir o que deve ser feito;

- Insistir em critérios objetivos.

No sentido oposto às técnicas para se extrair o máximo da contraparte, o método apresentado tende a produzir mais frutos quando ambos os lados o conhecem, e optam por colocá-lo em prática. No entanto, assim como as técnicas voltadas para a negociação distributiva, tal método apresenta o inconveniente de não resistir a processo de refutação.

\subsubsection{Outras recomendações não científicas}

Além das táticas distributivas ou integrativas, muitos outros temas podem ser encontrados na literatura não científica. Alguns autores preocupam-se em traçar estilos de negociação, e propõem que os negociadores identifiquem aquele estilo do qual mais se aproximam. Para Shell (2001, p. 9), o “[...] estilo pessoal é uma variável vital na negociação.” Por conta disso, o autor propõe a existência de cinco estilos: evita conflito; transigente; prestativo; competidor; e solucionador de problemas (Ibid., p. 11-12). O assunto também é abordado por Martinelli et al (2004, p. 109), para quem o conhecimento da descrição e características dos estilos de negociação facilita a identificação dos comportamentos e a classificação destes como positivos ou negativos.

Outro aspecto presente é a preocupação com o planejamento das negociações. Realizando pesquisa sobre o assunto, Shell (2001, p. 18) constatou que "[...] estudantes que usaram o sistema de preparação formal construíram melhores acordos tanto frente a frente como na rede de computadores, não somente para eles próprios, mas para ambas as partes.” Justamente visando ampliar os resultados auferidos com os acordos, Raiffa (2002, p. 15) propõe um roteiro para o planejamento das negociações, composto pelas seguintes fases: identificar o problema; tornar claro o objetivo; gerar alternativas criativas; avaliar as consequiências; e promover trocas entre as vantagens e desvantagens de cada alternativa, para selecionar a mais favorável. Lewicki et al (2002, p. 61) também apresentam uma proposta de passos, até mais detalhada do que a sugerida por Raiffa. 
Diferentemente das prescrições anteriores, esses conhecimentos não demandam a ignorância ou a participação da contraparte, para que possam surtir algum efeito positivo nas negociações. No entanto, também não constituem conhecimentos que possam ser submetidos a processos de refutação.

\subsubsection{Teoria dos Jogos}

O estudo das negociações foi amplamente influenciado pela Teoria dos Jogos. De acordo com Raiffa (2002, p. 53), o instrumental da Teoria dos Jogos traz uma poderosa contribuição para o problema da negociação, uma vez que remete o negociador a considerar como a contraparte pode responder às ações por ele empregadas. Para Sebenius (1992, p. 18), além de a Teoria dos Jogos ser especialmente útil para o entendimento de situações bem estruturadas, tem oferecido ferramentas para representar os desenhos das negociações, além de desvendar dinâmicas competitivas e gerar intrigantes hipóteses.

Mesmo reconhecendo que os limites entre o campo de estudo da Teoria dos Jogos e o das análises de negociação não são nítidos, Raiffa (2002, p. 6) procurou delimitá-los. Para o autor,

a Teoria dos Jogos analisa o comportamento interativo no qual os agentes decidem separadamente uns dos outros, mas a recompensa de cada um é função das escolhas de todos os tomadores de decisão envolvidos. Por outro lado, as análises de negociação consideram o comportamento interativo em que as partes se reúnem e decidem conjuntamente por meio de alguma colaboração. Ainda segundo o autor, quando cada uma das partes em conflito avalia se é benéfico iniciar uma negociação, as partes agem separadamente, o que constitui objeto de análise da Teoria dos Jogos. Caso optem por iniciar conversações, a matéria passa a ser de interesse dos estudiosos da negociação.

Essa proposta de delimitação, contudo, parece não ser satisfatória, já que a negociação não se limita às conversações, conforme mencionado anteriormente neste trabalho. Pelo contrário, de acordo com Shell (2001, p. 147), o processo de negociação envolve quatro etapas: preparação; troca de informações; proposta e concessão; e compromisso. Assim, o questionamento quanto ao benefício das conversações já se insere na etapa da preparação, portanto, integrando o campo de estudo das análises de negociação. 
Dessa maneira, além de os analistas de negociação poderem utilizar o instrumental da Teoria dos Jogos durante a etapa de preparação, pode-se afirmar que os teóricos dos jogos que se dedicam ao tema também estão tratando de uma vertente do estudo das negociações.

O mesmo raciocínio pode ser aplicado nas etapas seguintes. Freqüentemente, as recompensas do negociador dependem não somente das ações por ele promovidas, mas também das reações empregadas pela contraparte. Sempre que houver essa interdependência, as negociações podem ser representadas segundo os modelos desenvolvidos pela Teoria dos Jogos. Entre os inúmeros exemplos das escolhas que devem ser enfrentadas pelo negociador, pode-se citar a opção entre uma postura competitiva ou colaborativa. Além disso, o negociador sempre pode se questionar quanto à conveniência da continuidade ou encerramento das negociações. Nesse sentido, Fisher et al (1994, p. 119) afirmam que, em qualquer momento da negociação, as partes devem pensar na melhor alternativa à negociação de um acordo (MAANA).

Portanto, a Teoria dos Jogos é mais do que um mero instrumento para os analistas de negociação e negociadores, já que os adeptos dessa teoria também analisam as negociações. Partindo de pressupostos relacionados a regras do jogo, racionalidade, disponibilidade de informação e outros, a Teoria dos Jogos não somente analisa o comportamento, como também prescreve estratégias de ação. Esse entendimento é corroborado por Brams (2003, p. xxi), para quem muitos conflitos têm uma base racional. De acordo com o autor, as tentativas de chegar ao consenso podem fracassar em virtude de ser quase sempre racional as partes em disputa exagerarem suas posições. Assim, buscando utilizar-se da Teoria dos Jogos para a análise de negociações simples ou complexas, Brams, em seu livro "Negotiation games", explora os fundamentos racionais dos conflitos, para que estes possam ser solucionados por meio das negociações (Ibid., p. xxii).

No entanto, apesar das congruências entre Teoria dos Jogos e estudos de negociação, a maioria dos livros didáticos de negociação não recorre a análises fundamentadas pela Teoria dos Jogos, senão indiretamente. ${ }^{3}$ Por outro lado, pode-se encontrar uma série de artigos

\footnotetext{
${ }^{3}$ Embora alguns expoentes da literatura didática ou voltada para executivos reconheçam a importância da Teoria dos Jogos para o estudo das negociações, parecem não considerarem as possibilidades de utilização da informação assimétrica ou qualquer outro relaxamento de pressupostos. É o caso de Lewicki et al (2002, p. 5354), que ressaltam a necessidade de utilizar uma teoria mais pragmática para formular estratégias para o mundo real, já que a estratégia oriunda da Teoria dos Jogos "pressupõe que todos os jogadores tenham informações completas e perfeitas." Esse não reconhecimento das potencialidades da Teoria dos Jogos também é constatado em Sebenius (1992, p. 28), para quem a Teoria dos Jogos enfatizaria o caráter estratégico e plenamente racional
} 
científicos explorando o tema. Entre os trabalhos voltados para o estudo das negociações por teóricos dos jogos, podem ser destacadas as aplicações promovidas por Rubinstein (1982; 1985), Binmore et al (1989) e Rubinstein e Wolinsky (1992).

\subsubsection{Abordagem descritiva}

Os aspectos cognitivos passaram a constituir objeto de estudo dos analistas de negociação principalmente em razão da perspectiva denominada por Kahneman e Tversky (1987, p. 1) de descritivo-psicológica, ou simplesmente descritiva. Segundo os autores, contrapondo-se à concepção lógico-racional, que emprega métodos dedutivos para obter o comportamento de agentes racionais, a abordagem descritiva parte de observações empíricas e procura princípios gerais que possam explicar as crenças e preferências das pessoas.

Para Vazsonyi (1990, p. 320), os investigadores envolvidos nessa abordagem procuram desvendar como a mente humana funciona, e não como deveria funcionar. Alguns ainda dedicam especial atenção ao comportamento que foge à racionalidade no momento em que os indivíduos procuram solucionar problemas ou tomar decisões (Ibid., p. 318). Dessa maneira, ao voltarem-se para as interações entre os indivíduos, os estudos descritivos constituem uma nova perspectiva de estudo para as negociações.

Raiffa (1982, p. 20-21) afirma que a abordagem descritiva examina as formas de pensar e de se comportar frente a escolhas que envolvam risco. Ainda segundo o autor, seus adeptos pretendem investigar como as pessoas de carne e osso - petroleiros, banqueiros, generais, líderes sindicais, etc - analisam ou não analisam essas escolhas. Corroborando esse ponto de vista, Bell et al (1988, p. 16) afirmam que os estudos descritivos têm por motivação estudar como as pessoas pensam e agem, e ainda explicar o porquê dessa forma de pensar e agir. Entre outras aspirações mencionadas por estes autores, busca-se entender como as pessoas percebem as incertezas, acumulam evidências, refinam suas percepções, decompõem problemas complexos, pensam separadamente sobre as partes componentes dos problemas e reagrupam essas análises separadas.

das interações, ao passo que as análises de negociação combinariam o que o autor denomina de "tecnologia da cooperação" com uma visão limitadamente racional dos elementos estratégicos. 
Releva salientar que a maneira como as opções disponíveis são apresentadas numa negociação pode afetar a disposição de um negociador para chegar a um acordo (BAZERMAN; NEALE, 1998, p. 48). A título de exemplo, pode ser citado um experimento promovido por Kahneman e Tversky (1986, p. 124-125), no qual solicitou-se que as pessoas optassem entre uma alternativa que representava um resultado certo e outra que representava uma loteria. Quando as alternativas foram apresentadas em termos de ganho, as pessoas tenderam a escolher o ganho certo, demonstrando aversão ao risco. No entanto, quando as mesmas alternativas foram apresentadas em termos de perdas, a maioria dos entrevistados preferiu a loteria, demonstrando atração pelo risco.

Nesse sentido, Bazerman e Neale (1998, p. 21) afirmam que, em função de haver limites psicológicos impostos à eficácia das pessoas na negociação, torna-se necessária uma perspectiva psicológica para antecipar as prováveis decisões e subseqüente comportamento dos negociadores. No momento da decisão, existem tendências comuns que prejudicam os negociadores, impedindo-os de enxergar grandes oportunidades ou de tirar o máximo da negociação (Ibid., p. 18). O conhecimento desses vieses pode tornar o negociador consciente dos erros de avaliação a que ele está sujeito, tanto quanto auxiliá-lo a construir a escolha probabilística da contraparte (RAIFFA, 2002, p. 33).

Visando explorar algumas dessas tendências, Kahneman e Tversky (1995, p. 45) discutem como o excesso de confiança, o efeito certeza e a aversão a perdas poderiam prejudicar o sucesso das negociações. Entre os autores que procuram explorar os possíveis erros humanos no campo da negociação, destacam-se Bazerman e Neale (1998), que relatam "os (sete) erros mais comuns em negociação" no livro "Negociando racionalmente". ${ }^{4}$ A preocupação com tais vieses de percepção e julgamento também pode ser constatada em Lewicki et al (2002), que dedicam um capítulo ao tema no livro "Fundamentos da negociação".

\footnotetext{
${ }^{4}$ Os erros apontados por Bazerman e Neale (1998, p. 18) são:

a) Escalada irracional do compromisso - aumentar irracionalmente o compromisso com um curso inicial de ação, mesmo que esse curso de ação deixe de ser a escolha mais benéfica.

b) Crença na torta fixa - presumir que o ganho deve necessariamente sair à custa do outro, e perder oportunidades de trocas e concessões benéficas para ambos os lados.

c) Ancoragem - basear avaliações em informações irrelevantes, tais como uma oferta inicial.

d) Estruturação - ser demasiadamente afetado pelo modo como as informações são apresentadas.

e) Excesso de confiança - depender excessivamente das informações prontamente disponíveis e ignorar dados relevantes.

f) Praga do vencedor - deixar de considerar o que pode ser aprendido ao colocar-se na perspectiva do outro lado da negociação.

g) Disponibilidade de informações - ter confiança demais em obter resultados favoráveis.
} 


\subsection{Proposta formulada por Raiffa}

De forma geral, pode-se dizer que as análises de negociação têm uma finalidade normativa, visando ao aconselhamento das partes na tomada de decisão. A probabilidade de sucesso desse aconselhamento aumenta se o analista tiver mecanismos suficientes para elaborar predições confiáveis quanto aos resultados e recompensas de cada um dos envolvidos na negociação. Assim, necessitando prever as possíveis reações do outro lado, bem como as eventuais respostas a essas reações, torna-se salutar o tratamento do tema como ciência, tal como propõem as análises da Teoria dos Jogos e da abordagem descritiva.

Já foi visto que, amparados em diferentes pressupostos, os modelos propostos pela Teoria dos Jogos permitem a antecipação de resultados e recompensas, e a conseqüente prescrição aos agentes envolvidos. Do mesmo modo, o conhecimento dos mais variados vieses cognitivos permite que o negociador evite erros freqüientes em negociação, e ainda esteja mais preparado para identificar algum erro da contraparte.

A propósito, o simples conhecimento de que existe uma tendência em perceber negociações como distributivas (BAZERMAN; NEALE, 1998, p. 33) já pode auxiliar os negociadores a obter melhores resultados, uma vez que evitarão assumir previamente que o bolo a ser partido é fixo. Ocorre que a maioria esmagadora das negociações tem características integrativas e distributivas. Apesar de existirem aspectos essencialmente distributivos, quando se analisa a negociação de forma ampla, encontra-se grande potencial integrativo. O estudo das negociações deve ter essas particularidades em conta, se pretende promover predições confiáveis a um escopo abrangente de aplicações.

Como forma de integrar as diferentes abordagens discutidas na seção 2.2, Raiffa (1982, p. 45) propôs que as negociações sejam analisadas por meio da representação dos valores de reserva das partes. Essa abordagem permitiu uma formalização para o estudo dos processos de negociação. Para o presente trabalho, essa representação assume papel fundamental já que, no capítulo 4, é utilizada como ponto de partida para o estudo das renegociações que se desenvolvem após uma das partes ter promovido investimentos específicos. Em razão da importância do tema para este trabalho, o conceito e as aplicações do valor de reserva são tratados no próximo capítulo, de maneira apartada. 


\section{VALOR DE RESERVA: O MODELO PROPOSTO POR RAIFFA}

\subsection{Conceito}

Neste capítulo, é demonstrado como as negociações podem ser representadas a partir do valor de reserva (VR) de cada um dos lados envolvidos. ${ }^{5}$ O VR pode ser entendido como uma ferramenta para auxiliar os negociadores e estudiosos do assunto na análise de negociações distributivas (seção 3.2) e integrativas (seção 3.3). Apesar de haver limitações à aplicação desse conceito (seção 3.4), a representação das negociações a partir do VR das partes é decisiva na proposta de estudo das renegociações apresentada no capítulo 4.

O VR é o nível mínimo aceitável para que o negociador concorde com o acordo, ou com determinado termo do acordo. De acordo com Shell (2001, p. 33), pode ser entendido como o valor para a retirada estratégica ou a condição básica para a preservação da negociação. Freqüentemente, utiliza-se esse conceito para a variável preço. Assim, o padrão para o estabelecimento do acordo é o VR, entendido como o preço mais desfavorável para a parte, mas que ainda torna o acordo aceitável. Com isso, o VR do vendedor é aquele preço mínimo pelo qual ele esteja disposto a vender. Na ponta oposta da transação, o VR do comprador é aquele preço máximo pelo qual ele esteja disposto a comprar.

\subsection{Valor de reserva em barganhas distributivas}

Conforme já exposto, em negociações distributivas há somente um tema em pauta e os interesses são antagônicos. Para o propósito desta seção, as partes envolvidas na negociação são representadas pelo vendedor e pelo comprador de um bem qualquer, sendo que o tema em discussão é o estabelecimento do preço. O modelo, entretanto, poderia ser utilizado para a análise de qualquer outra variável discreta ou contínua, como o diâmetro do produto, a

\footnotetext{
5 O termo "valor de reserva" ou "preço de reserva" tem sido por vezes substituído na Teoria dos Jogos por “disagreement payoff" ou, como preferem Binmore et al (1989), "outside option".
} 
quantidade de funcionários envolvidos no projeto ou o prazo de pagamento. ${ }^{6}$ Releva notar que a situação descrita pode espelhar a negociação entre empresas integrantes de uma mesma cadeia produtiva, bem como a negociação entre franqueador e franqueado, ou ainda entre empresas parceiras num mesmo negócio.

Para chegar-se ao VR, é importante que as partes descubram as alternativas à negociação. De acordo com Fisher et al (1994, p. 120), a razão pela qual se negocia é produzir algo melhor do que os resultados que seriam possíveis obter sem negociar. Por esse motivo, a melhor alternativa à negociação de um acordo (MAANA) é o padrão em relação ao qual a proposta de acordo deve ser medida. Tais autores sustentam que o estabelecimento de qualquer outro piso mínimo poderia gerar elevados ônus, inibindo a imaginação quanto às alternativas existentes ou impedindo a aceitação de um acordo favorável (Ibid., p. 119).

Assim, antes que se iniciem as conversações, mas também enquanto elas se desenvolvem, é vital que as partes avaliem as alternativas ao acordo e identifiquem a MAANA, que será o ponto de partida para o estabelecimento do VR. Quanto a isso, Raiffa (2002, p. 221) salienta que os envolvidos devem atentar à natureza do problema e aos seus reais objetivos para determinar a MAANA. Dessa maneira, na opinião desse autor, a celebração de uma aliança com o fornecedor de um insumo não é o problema que a empresa deve enfrentar, mas talvez seus dirigentes devam se questionar quanto à maneira pela qual a empresa pretende crescer, ou quanto ao melhor caminho para explorar determinado negócio.

Essa distinção é relevante porque, se o problema for definido da primeira forma, as alternativas ao acordo envolvem apenas as negociações com outras empresas. Todavia, identificando a verdadeira questão, podem surgir mais alternativas ao acordo, tais como a expansão das atividades, as aquisições e fusões, a celebração de parcerias e alianças estratégicas, etc. $\mathrm{O}$ negociador deve até empreender esforços para melhorar sua MAANA, aperfeiçoando as idéias promissoras e transformando-as em opções práticas (FISHER et al, 1994, p. 123), para que possa negociar em condições favoráveis (WATKINS, 2004, p. 31).

Dessa forma, mediante a análise das conseqüências de não se chegar a um entendimento, cada negociador estabelece o valor mínimo para aceitação do acordo, denominado VR (RAIFFA,

\footnotetext{
${ }^{6} \mathrm{O}$ modelo pode ser construído com variáveis que digam respeito ao produto, tais como qualidade, dimensão e peso; e com aquelas relacionadas à transação, como prazo de entrega e condição de pagamento.
} 
1982, p. 45). Portanto, o VR não representa um número mágico, mas reflete o resultado a ser obtido pela empresa, no caso de as negociações fracassarem.

Uma vez que cada uma das partes determinou seu VR, haverá zona de acordo sempre que o valor de reserva do comprador (B) for superior ao valor de reserva do vendedor (S). Caso os negociadores cheguem a um acordo, e admitindo a ausência de qualquer outra negociação, concreta ou potencial, que afete o desfecho da transação, espera-se que o preço final contratado esteja dentro da zona de acordo.

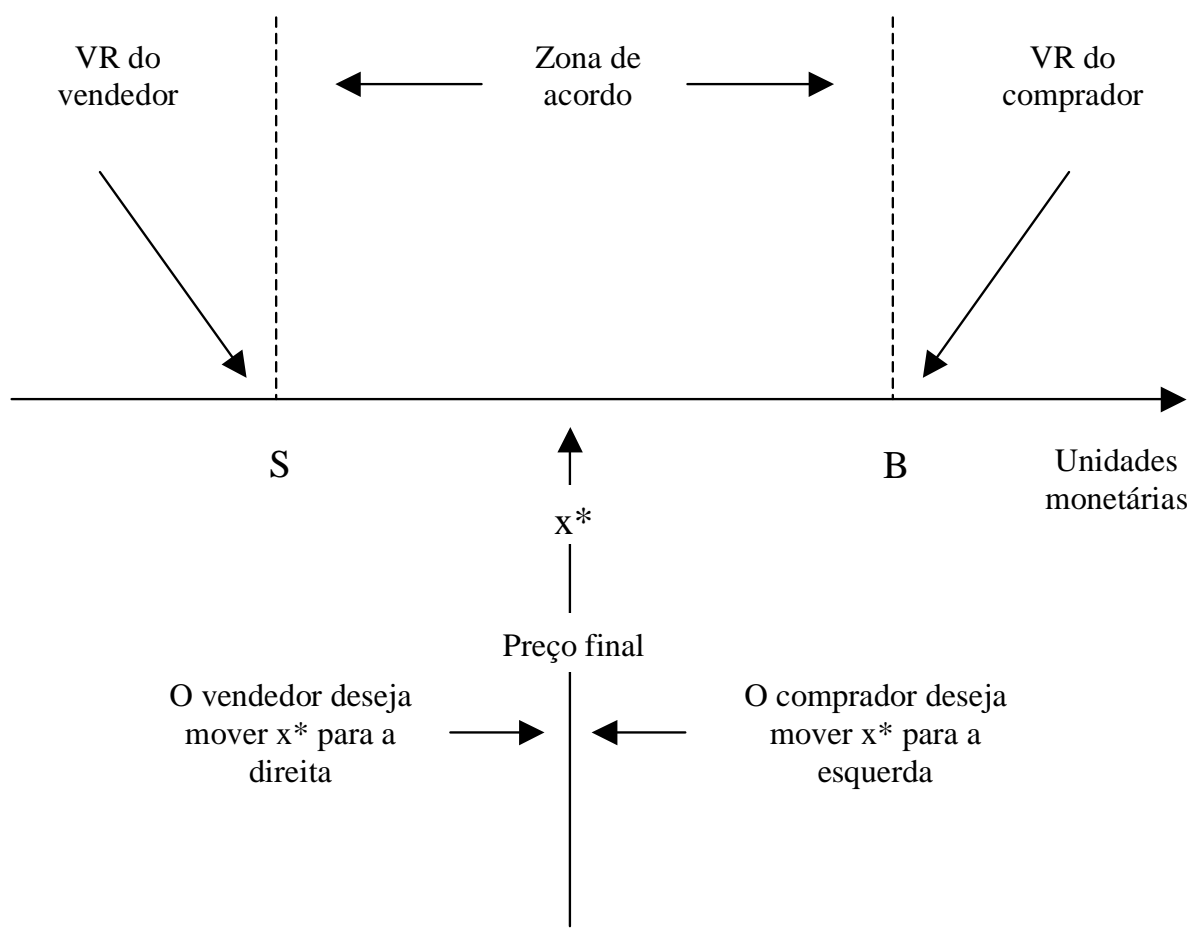

Ilustração n⿳ 1 - Modelo analítico para duas partes e um só tema FONTE: RAIFFA, 1982, p. 46

Admitindo que o preço final acordado ( $\mathrm{x}^{*}$ ) esteja dentro da zona de acordo, denomina-se como excedente a diferença entre o preço acordado e o VR de cada parte. Assim, pode-se constatar na ilustração 1 que o vendedor obterá por excedente $x^{*}-\mathrm{S}$, e o comprador obterá B - $x^{*}$. Sobre o assunto, Raiffa (1982, p. 45-46) pondera que não se trata de um jogo de soma constante de valor igual ao excedente $\mathrm{B}-\mathrm{S}$, já que existe a possibilidade de as partes não lograrem um acordo. Conforme Brams (2003, p. 29), tais situações constituem um dilema ao negociador, já que quanto mais as partes se preocupam em maximizar seus interesses individuais, maiores são as chances de não concluírem o acordo. 
Se as partes chegarem ao acordo, há distribuição do excedente $\mathrm{B}-\mathrm{S}$ entre elas. Contudo, a fatia que cabe a cada lado depende de uma série de fatores que interferem no poder relativo dos negociadores. Entre esses fatores podem ser citados: a disponibilidade de tempo para fechar o acordo (COHEN, 1980, p. 93); o valor adicional que cada uma das partes proporciona para a transação (NALEBUFF; BRANDENBURGER, 1996, p. 58); e a unidade interna de cada uma das partes (RAIFFA, 1982, p. 12).

Segundo Cohen (1980, p. 102), uma outra variável importante na partilha do excedente é a informação, pois o conhecimento dos limites da outra parte fornece uma grande vantagem para o negociador. No mesmo sentido, Watkins (2004, p. 32) afirma que o conhecimento da MAANA do outro lado é fonte de poder na hora da negociação. Reconhecendo esse fato, Lewicki et al (2002, p. 76) afirmam que, em situações de barganha distributiva, "Uma estratégia importante é guardar as informações cuidadosamente - uma parte tenta fornecer informações ao outro somente quando isso lhe traz alguma vantagem estratégica. Enquanto isso, é bastante desejável conseguir informações da outra parte para aumentar o poder de negociação."

De acordo com Sebenius (1992, p. 21), os analistas de negociação tipicamente centram sua atenção nas percepções subjetivas das denominadas "zonas de possível acordo". Isso porque a essência de muitas barganhas distributivas envolve as incertezas de cada parte acerca do VR mantido pelo outro lado (Ibid., p. 23). Daí, além de o comprador buscar informações sobre S, poderá tentar iludir o vendedor sobre o valor de B, fazendo com que B pareça inferior ao seu valor real (RAIFFA, 1982, p. 46-47). Nessa mesma linha, Sebenius (1992, p. 24) consigna que o negociador pode até mesmo manipular a percepção da outra parte quanto às alternativas por ele detidas, tanto quanto a avaliação subjetiva dessas alternativas. Naturalmente, podem ser levantados questionamentos éticos quanto ao emprego de mentiras e a outras práticas visando à manipulação no curso das negociações.

Apesar da importância atribuída às informações sobre os limites de cada um dos lados, Raiffa (2002, p. 111) afirma que muito freqüentemente os negociadores possuem uma idéia imprecisa do seu próprio VR e somente fazem tentativas informais de acesso à distribuição de probabilidade do VR da outra parte. 
Se a assimetria de informação é um aspecto importante das negociações, por outro lado, mesmo que os preços reservados sejam amplamente conhecidos pelas partes, a repartição do excedente não se torna uma questão trivial, em face de os envolvidos terem diferenças na riqueza inicial, nos custos relacionados ao tempo, na determinação pessoal ou agressividade, nas avaliações marginais, nas necessidades, etc (Ibid., p. 118).

Em termos de estratégia de negociação, estudos apontam que ofertas iniciais extremadas fornecem aos negociadores resultados mais favoráveis do que ofertas iniciais mais baixas ou modestas (LEWICKI et al, 2002, p. 91). A realização de testes empíricos por Raiffa (2002, p. 114) demonstrou que a melhor predição para o preço final é a média entre as ofertas iniciais, se ela estiver dentro da zona de acordo. No entanto, se a média entre essas ofertas iniciais estiver fora da zona de possível acordo, é muito difícil fazer qualquer previsão para o preço final.

Outro dado empírico de relevo é que a estratégia de Boulware ${ }^{7}$ poucas vezes funcionou, pois causava desconfiança na outra parte pelo fato de não ser correspondida nas concessões promovidas (Ibid., p. 114). No mesmo sentido, Lewicki et al (2002, p. 94), afirmam que há significativas evidências de que as partes se sentem melhor em relação a um acordo quando a negociação envolve uma progressão de concessões.

Ainda em relação à abertura das ofertas iniciais, Shell (2001, p. 197) recomenda que o negociador sinta-se à vontade para fazer o primeiro lance, caso acredite que suas informações a respeito do valor de mercado do objeto negociado sejam melhores do que aquelas detidas pelo "oponente". 8 No entanto, se o negociador estiver menos confiante em sua avaliação, o autor aconselha deixar a iniciativa para a outra parte, recomendando apenas cuidado para não se trair pelo efeito da ancoragem. ${ }^{9}$ Mesmo que o negociador possa ter suas expectativas reduzidas em razão da oferta inicial agressiva da contraparte, Cohen (1980, p. 132) afirma que o silêncio muitas vezes é uma boa tática porque induz a outra parte a falar, fornecendo informações importantes.

\footnotetext{
${ }^{7}$ Lemuel Boulware, ex-vice-presidente da GE, raramente fazia concessões em negociações amplas. Portanto, a estratégia de Boulware consiste em fazer uma oferta inicial razoável e manter-se firme, sem concessões.

${ }^{8}$ O emprego dado ao termo "oponente" está alinhado com a característica da barganha distributiva, em que o ganho de um sai à custa do outro. Porém, conforme já comentado, não se deve inferir precipitadamente que a negociação é apenas distributiva, atribuindo ao potencial colaborador o rótulo de oponente.

${ }^{9}$ Ver nota de rodapé 4.
} 


\subsection{Valor de reserva em acordos integrativos}

Apesar de o modelo apresentado ser de grande utilidade na descrição do comportamento das partes envolvidas, sua utilização é direta apenas na negociação distributiva. Na seção 3.2, considerou-se um relacionamento entre duas partes, cujos interesses, claros e conflitantes, diziam respeito a uma única dimensão. Na discussão promovida, o único tema em pauta foi o preço, sendo que os interesses eram claramente conflitantes. Enquanto o comprador desejava obter o menor preço, o vendedor procurava elevá-lo. Ainda que o modelo permita a substituição dessa variável por outra, basicamente estaria analisando uma só variável, relacionada ao produto ou à transação. Tratar-se-ia de uma única dimensão, um único tema.

No entanto, dificilmente o processo de negociação envolve apenas uma questão. Freqüentemente, há muitos aspectos a serem discutidos além do preço, da data de entrega, ou de qualquer outra questão isolada (WATKINS, 2004, p. 19). Lewicki et al (2002, p. 125) opinam que, quase sempre, há mais de um tipo de interesse em disputa, sendo que os agentes podem estar preocupados com o processo, a relação ou os princípios em jogo. Sobre o assunto, Lax e Sebenius (1986, p. 243) classificam os interesses mantidos pelas partes em:

a) Intrínsecos - avaliados em si mesmo pelas partes, como o custo, a qualidade e o tempo;

b) Processuais - relacionam-se com a forma de resolver a disputa, como a reputação, a justiça e o relacionamento entre os envolvidos.

Quando há mais temas em jogo, freqüentemente existem questões em que os interesses não são conflitantes, abrindo espaço para soluções integrativas. Além disso, as partes podem ceder em uma questão, a fim de conquistar concessões relativas a temas de maior interesse. Conforme já comentado neste trabalho, abre-se espaço para trocas, tornando a negociação integrativa.

Nessas condições, havendo espaço para as partes conciliarem interesses de forma a ampliar o ganho de todos os envolvidos, é muito difícil fazer qualquer previsão acerca do resultado final. Essas possibilidades são demonstradas na ilustração 2: os eixos vertical e horizontal, o arco convexo, e a área por eles delimitada representam a gama de resultados possíveis para os dois lados. Tais resultados, entretanto, não refletem uma dimensão específica, como o preço 
do produto ou o prazo de entrega, mas a utilidade ou valor atribuído a um conjunto de questões. O aludido arco é denominado de fronteira de Pareto, já que em qualquer dos pontos não é possível melhorar o resultado de uma das partes sem prejudicar alguma outra (Ibid., p. 247).

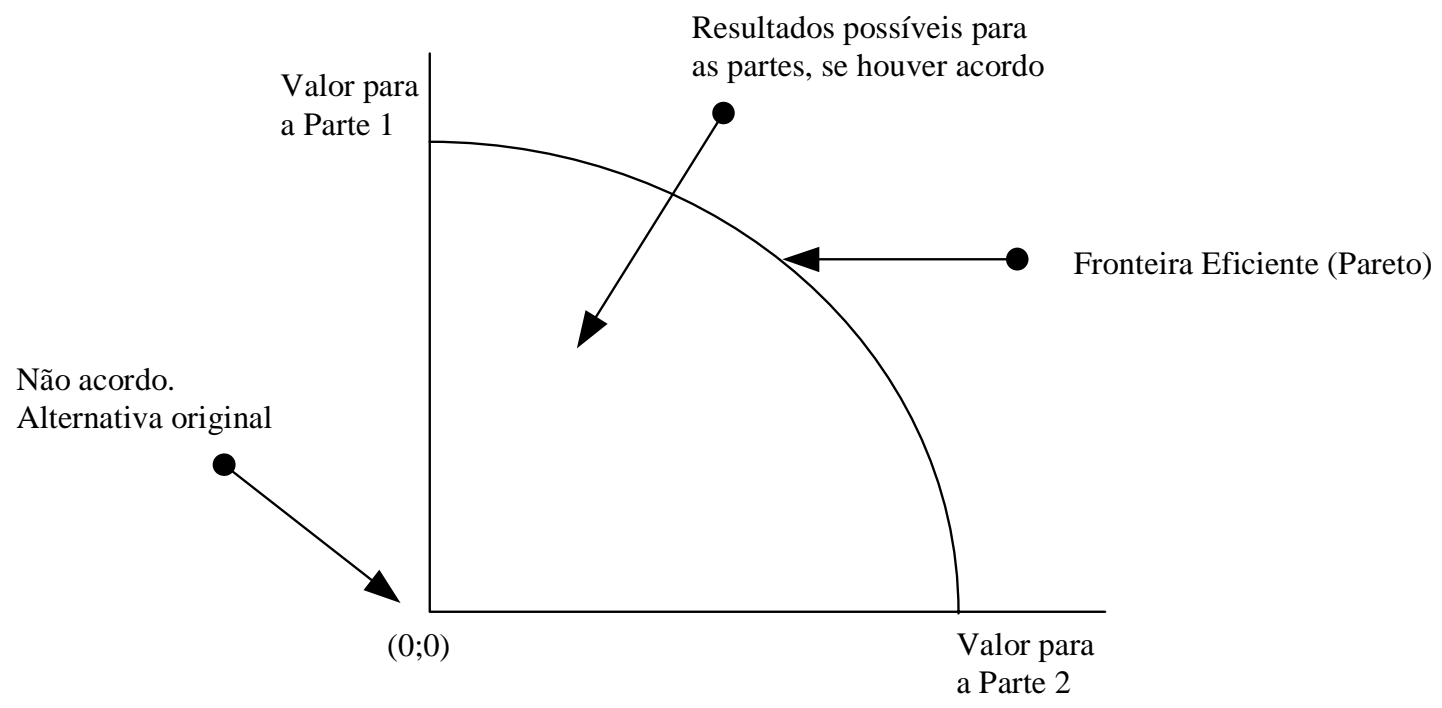

Ilustração $\mathrm{n}^{0} \mathbf{2}$ - Modelo analítico para o acordo integrativo

FONTE: LAX; SEBENIUS, 1986, p. 248

Em razão de o ganho conjunto com a transação ser variável quando há mais de uma questão sobre a mesa de negociações, a troca de concessões é fundamental para que as partes atinjam a fronteira de Pareto. Contudo, como geralmente nenhuma das partes conhece a localização dessa fronteira, a dificuldade na obtenção do acordo reside em inventar meios para mover-se em sua direção (Ibid., p. 247). Ocorre que além da motivação por ampliar o ganho conjunto com o compartilhamento de informações, cada um dos lados tem estímulos a ocultar uma ou outra informação, a fim de aumentar - ou mesmo proteger - sua fatia na distribuição de resultados. Esse conflito de motivações é conhecido como o dilema do negociador (SEBENIUS, 1992, p. 30; RAIFFA, 2002, p. 85).

A fim de facilitar o processo de negociação, Raiffa (2002, p. 220-233) advoga a utilização do VR mesmo em negociações que não sejam perfeitamente distributivas. No entanto, o cálculo do VR deve agregar todas as questões relevantes da transação. Conforme o autor, as partes devem avaliar quantitativamente as questões, bem como os possíveis resultados associados a 
cada uma delas. Para isso, é conveniente determinar o valor - ou a utilidade - de itens quantitativos e qualitativos.

Na tabela 1, é demonstrada uma avaliação hipotética, em que um comprador seleciona atributos entendidos como relevantes na transação: nível de qualidade; preço; e prazo de pagamento. Considerando o valor ou utilidade atribuída a cada resultado, pode-se dizer que se a empresa compradora tiver por melhor alternativa a aquisição de um produto de boa qualidade, ao preço de $\$ 30$, para pagamento em 60 dias, a MAANA apresentará um valor ou utilidade de 7, o que representa exatamente o VR da empresa.

Tabela $\mathbf{n}^{0} 1$ - Valor de reserva em acordos integrativos

\begin{tabular}{ccc}
\hline Temas & Resultados & Valor (Utilidade) \\
\hline Nível de Qualidade & Ótima & 10 \\
& Bceitável & 4 \\
Preço & $\$ 20$ & 0 \\
\hline Prazo de pagamento & \$30 dias & 3 \\
& À vista & 3 \\
\hline
\end{tabular}

Conforme Raiffa (2002, p. 223), sem esse procedimento formal, existe uma tendência ao tratamento dessas questões de forma separada, fazendo com que o negociador imponha restrições em cada uma das questões. No exemplo dado, alguns negociadores talvez não aceitem um prazo de pagamento menor que 60 dias, ainda que disponham da combinação produto ótimo e preço de \$20. Cabe notar que, mesmo com o pagamento à vista, essa composição de qualidade e preço confere à empresa uma utilidade de 16. Embora a existência de um fornecedor concedendo 60 dias para pagamento possa e deva ser utilizada como argumento durante as negociações, não deve ser visto como um piso para a negociação, prejudicando a celebração de um acordo mais favorável. 
Por fim, deve-se considerar que todo esse leque de questões freqüentemente é conhecido apenas imperfeitamente pelos negociadores (SEBENIUS, 1992, p. 24). Assim, como raramente é possível a quantificação de todos os temas e seus possíveis resultados, Raiffa (2002, p. 223) comenta que em muitas ocasiões pode ser suficiente a realização das análises qualitativas entre as diferentes questões e os resultados factíveis em cada uma delas.

\subsection{Limitações na utilização do modelo}

A representação das negociações em torno do VR detido pelas partes apresenta uma série de benefícios aos negociadores: estimula a busca pelas alternativas ao acordo; auxilia o negociador a não fechar acordos que lhe seriam insatisfatórios; e evita que se percam oportunidades. Apesar dessas vantagens, Shell (2001, p. 35) acredita que a ênfase no VR pode trazer algum prejuízo para o negociador despreparado, já que os seres humanos possuem uma capacidade limitada para manterem-se centrados em situações complexas, e o VR pode emergir como ponto de referência dominante, inibindo uma meta de negociação mais ambiciosa.

Por esse motivo, ainda que considere a importância do VR para o fechamento do acordo, Shell (2001, p. 36) recomenda que as metas devam ser objeto de maior atenção do que os valores de reserva. Tendo isso em conta, o autor aconselha que o negociador se oriente por uma meta agressiva durante o planejamento da negociação e as primeiras conversações, para depois atentar ao VR, utilizando-o somente para avaliar se o acordo é favorável.

Além da restrição apontada pelo autor, existem situações em que a aplicação do VR é mesmo inadequada. Isso porque o mundo das negociações pode apresentar situações mais complexas do que a retratada, como a existência de mais de duas partes envolvidas. Além disso, Lax e Sebenius (1986, p. 242) afirmam que é possível que as partes não sejam monolíticas, isto é, os lados podem apresentar divisões internas quanto aos interesses em jogo, dificultando a construção de um único valor de reserva. Outra limitação para o uso do VR diz respeito aos interesses. O modelo prevê que os envolvidos estejam procurando maximizar a sua utilidade ou benefício. Caso uma ou mais partes esteja desinteressada em maximizar sua utilidade, ou tenham outros interesses concorrentes, não faz sentido pensar na zona de acordo. 
Embora as negociações paralelas também possam afetar o modelo, é possível incorporar ao VR o ganho ou perda esperada com o relacionamento amplo com a outra parte. Desse modo, a interferência de outras negociações tem efeito idêntico ao interesse na relação de longo prazo, podendo ser levada em conta na construção do VR. 


\section{NEGOCIAÇÃO PÓS-ACORDO}

\subsection{Justificativa de estudo}

No panorama traçado no capítulo 2, foram discutidas algumas perspectivas para os estudos das negociações, sem que fosse atribuído maior interesse à questão das renegociações. De fato, muitas transações resolvem-se no ato, sem que haja necessidade de negociações futuras. Mesmo acordos que se mostram desfavoráveis para uma das partes podem não acarretar negociações adicionais, se o outro lado se opor a renegociar os termos do acordo ou se o restabelecimento das conversações envolver custos proibitivos. Nesses casos, a negociação de problemas ex-post pode ser uma alternativa pouco realista.

No entanto, com a especialização das organizações econômicas em atividades distintas, presencia-se uma profunda interdependência entre as empresas, atadas em relacionamentos de médio e longo prazo. É possível que a simples compra-e-venda, sem qualquer obrigação ou efeito posterior, constitua exceção e não regra no relacionamento entre as organizações econômicas. Isso porque muitos acordos prevêem efeitos continuados. São exemplos de acordos com essa particularidade: o contrato de fornecimento de bens; a prestação de serviços por prazo determinado; a aliança estratégica; a franquia; a venda com entrega futura; a prestação de garantias; etc.

Ocorre que os termos acordados nas negociações amiúde precisam ser revistos, o que faz com que as empresas necessitem estabelecer processos de renegociação. Portanto, mesmo depois que os acordos são fechados, é provável que as partes envolvidas na transação necessitem voltar à mesa de negociações para tratar de situações não previstas anteriormente. Principalmente no meio empresarial, as renegociações dos acordos e contratos são freqüentes.

A esse respeito, apesar de os livros de negociação não dedicarem maior interesse às renegociações, entende-se neste trabalho que a literatura sobre contratos incompletos desenvolve uma abordagem que merece ser considerada. Consoante Hackett (1994, p. 363), os trabalhos de Williamson (1987) e Klein et al (1978) possibilitaram a construção do modelo de contratação incompleta pelos teóricos dos jogos. Nesse modelo, geralmente apresentam-se 
dois estágios distintos: no primeiro, os agentes promovem os investimentos específicos em relacionamentos não contratáveis; e no segundo, barganham a distribuição do excedente gerado. Entre os trabalhos que tratam do assunto, podem ser destacados os desenvolvidos por Hart e Moore (1988) e Tirole (1986; 1999).

Tal abordagem também serviu de base para o desenvolvimento de pesquisas experimentais, em que são simulados esses dois estágios da contratação incompleta. Merece destaque a simulação em laboratório promovida por Hackett (1994), na qual o pesquisador teve por objetivo verificar se um contrato relacional ${ }^{10}$, definido pelo autor como um elo implícito entre os investimentos específicos e as regras de divisão do excedente, poderia surgir mesmo na ausência de contratos freqüentemente repetitivos e de efeitos da reputação.

Apesar da relevância das renegociações, cabe notar que Raiffa não previu explicitamente a possibilidade de representá-las com base da zona possível de acordo. Por outro lado, o autor não apresentou contra-indicações para a utilização do modelo nessas situações. Assim, tendo em vista que a renegociação constitui, apesar das suas particularidades, um genuíno processo de negociação, é natural que se pressuponha a possibilidade de seu estudo por meio da representação do VR das partes. Dessa forma, pode-se dizer que sempre foi possível a utilização da zona de possível acordo para analisar as renegociações.

Além de explorar a utilização do VR para o estudo das renegociações, este capítulo tem por propósito demonstrar que o VR pode se alterar entre a negociação e a renegociação. Em outras palavras, ainda que o processo de renegociação traduza-se por uma negociação como qualquer outra, existe um aspecto que deve ser considerado: entre a negociação e a renegociação, o poder relativo do agente pode ser decisivamente afetado por conta de eventuais mudanças no VR de algum dos envolvidos. Outro aspecto ainda tratado neste capítulo é o comportamento que a parte beneficiada adota durante o processo de renegociação.

Para explicar o porquê das renegociações, bem como possíveis causas e conseqüências da alteração no VR de uma das partes, optou-se por incorporar alguns elementos da Economia dos Custos de Transação (ECT). Embora outros autores apresentem importantes contribuições

10 "Relational exchange” 
à teoria mencionada (GHOSHAL; MORAN, 1996, p. 16), recorre-se fundamentalmente aos trabalhos desenvolvidos por Williamson $(1987$; 1993; 1996), Klein et al (1978) e Klein (1996), motivo pelo qual as citações à ECT referem-se exclusivamente às contribuições desses autores e de seus seguidores. Desses estudos, são emprestados os pressupostos comportamentais da racionalidade limitada e oportunismo, além do atributo das transações denominado de especificidade dos ativos.

O primeiro conceito, apresentado na seção 4.2, é a racionalidade limitada, pressuposto comportamental dos agentes que determina a incompletude contratual. A seguir, na seção 4.3, tendo-se em conta a necessidade de renegociações nas revisões contratuais, discute-se o efeito da especificidade dos ativos sobre o VR. Na seção 4.4, é apresentado o conceito de oportunismo. No entanto, apesar de a ECT adotá-lo como pressuposto comportamental dos agentes, não se esposa neste trabalho o comportamento oportunista como pressuposto. Pelo contrário, busca-se exatamente discutir se as pessoas se comportam ou não de maneira oportunista nas transações a que se expõem no mundo real. Conforme é demonstrado na seção 4.5, há restrições à postura oportunista, bem como existe a possibilidade de o contratante não ter a intencionalidade oportunista. Por fim, a seção 4.6 apresenta algumas evidências empíricas do comportamento manifestado pelos agentes.

\subsection{Racionalidade limitada}

Muitos modelos, especialmente no pensamento econômico ortodoxo, adotam o pressuposto comportamental da racionalidade plena dos agentes (FARINA et al, 1997, p. 43). Por esse conceito, os indivíduos seriam "[...] capazes de absorver e processar toda informação disponível e, assim, agir de modo a maximizar seu objetivo, seja utilidade, lucro, receita ou qualquer outro similar" (Ibid., 72).

De forma semelhante, Fiani (2004, p. 9) entende que admitir racionalidade plena implica supor que os indivíduos empregam os meios mais adequados aos objetivos por eles almejados, sejam quais forem esses objetivos. Mesmo o indivíduo que aceita perder dinheiro para punir alguém que lhe feriu, pode estar agindo com racionalidade plena, se essa ação lhe proporcionar a maximização da sua utilidade. De acordo com Nalebuff e Brandenburger 
(1996, p. 74), as pessoas são motivadas por diferentes interesses, de tal sorte que a maximização de suas utilidades incorpora sentimentos de orgulho, justiça, ciúme, despeito, vingança, altruísmo, caridade, etc. Portanto, o reconhecimento dessas dimensões não necessariamente afeta o que se entende por racionalidade plena.

A restrição à racionalidade plena se manifesta quando o agente, mesmo tendo uma motivação racional, não se comporta da maneira que o levaria a maximizar os seus interesses. Nesse sentido, Kreps (1990, p. 151) afirma que apesar de o indivíduo agir conscientemente na busca de alguns objetivos, o caminho por ele trilhado reflete suas limitações cognitivas e computacionais. Isso porque as pessoas estão sujeitas a vieses de percepção, julgamento e processamento das informações.

Sobre o assunto, Fiani (2004, p. 9-10) afirma que o próprio desejo de sucesso em relação aos seus objetivos pode distorcer tanto as hipóteses em relação à melhor maneira de atingir os objetivos, como o levantamento das informações necessárias. Ainda segundo esse autor, o estado emocional pode impedir que o tomador de decisão avalie as conseqüências das suas possíveis ações, mesmo quando de posse de todas as informações necessárias.

A esse respeito, a Economia dos Custos de Transação propõe que os agentes humanos estão sujeitos a uma racionalidade limitada (WILLIAMSON, 1987, p. 45), de modo que "[...] o comportamento é intencionalmente racional, mas somente de maneira limitada [...]"11 (SIMON, 1957, p. xxiii), assim contrapondo-se ao conceito do indivíduo capaz de desenvolver cálculos complexos com rapidez, precisão e sem custos em seu processo decisório (FARINA et al, 1997, p. 43).

Utilizando-se do exemplo apresentado por Farina et al (1997, p. 73), o pressuposto da racionalidade limitada implica que o empresário se empenharia em obter o maior lucro possível para a empresa. No entanto, conforme explicam os autores, a obtenção das informações necessárias às decisões para atingir esse objetivo, assim como a capacidade de processamento de contratos complexos que dêem conta de todas as contingências, é limitada ou, na melhor das hipóteses, dispendiosa. Consoante destaca Klein (1996, p. 447), num mundo incerto, a especificação contratual completa tem um custo, associado principalmente

11 “[...] human behavior is intendedly rational, but only limitedly so [...]” 
com o descobrimento de todas as potenciais contingências e com a negociação das respostas contratuais necessárias.

Para Williamson (1987, p. 46), nem mesmo é possível promover a contratação completa quando se considera a racionalidade limitada dos indivíduos. Assim, não conseguindo prever todas as contingências futuras, os contratos celebrados entre os agentes são necessariamente incompletos. Por outro lado, sendo racionais, os agentes reconhecem essa limitação, estando cientes da necessidade de adaptações e negociações contratuais ex-post (FARINA et al, 1997, p. 73).

Para o propósito deste trabalho, não importa determinar quais são os vieses cognitivos que impedem o exercício da racionalidade plena, tampouco a forma como eles afastam os indivíduos do comportamento racional. Da mesma maneira, também não é objeto de interesse descobrir se os limites de processamento tornam a completude contratual impossível ou demasiadamente dispendiosa. É suficiente admitir que apesar da motivação racional, interessada em maximizar a utilidade, existem limites, sejam eles de percepção, julgamento ou processamento, que tornam os contratos na vida real necessariamente incompletos. Em outras palavras, tendo em conta que os indivíduos são apenas limitadamente racionais, "A contratação completa não é uma alternativa realista [...]"12 (WILLIAMSON, 1987, p. 46).

Além disso, alguns fatores tornam a contratação ainda mais complexa. Por exemplo, Nelson e Winter (1982) citados por Argyres e Liebeskind (1999, p. 54) afirmam que é muito difícil antecipar riscos e oportunidades futuras em indústrias que apresentam rápida inovação tecnológica. Porém, mesmo em setores mais tradicionais, os contratos de longo prazo abrem algum espaço para renegociação, devido a incertezas quanto aos preços e demanda no futuro (ARGYRES; LIEBESKIND, 1999, p. 55).

Mesmo que as empresas dediquem mais tempo e empenho na confecção de um contrato mais elaborado, que preveja uma maior quantidade de contingências, a contratação ainda não será completa. A própria elevação de cláusulas contratuais pode ensejar situações que favoreçam decisivamente uma das partes em detrimento da outra, ou que elevem desnecessariamente a rigidez da transação (KLEIN, 1996, p. 447). No extremo oposto, é possível que os

\footnotetext{
12 "Comprehensive contracting is not a realistic organizational alternative [...]"
} 
negociadores cheguem ao acordo, mas não assinem um contrato que possa ser assegurado pela justiça ou por alguma outra terceira parte. Nesse caso, as partes dependem de outros mecanismos para assegurar o cumprimento dos termos acordados. De uma maneira ou de outra, entretanto, sempre que o acordo tiver efeitos de duração continuada, é possível - mais do isso, é provável - que as partes necessitem engendrar renegociações para tratar de situações imprevistas.

Por esse motivo, é importante ter em conta que o processo de negociação extrapola a celebração do acordo. Segundo afirmam Andrade et al (2004, p. 14), uma negociação só deve ser considerada encerrada quando o acordo foi cumprido e não quando foi formalizado. Dessa forma, se freqüentemente o sucesso da negociação depende de que as partes promovam concessões e conciliem interesses; depois de celebrado o acordo, muitas vezes será necessário voltar à mesa de negociações para tratar de comportamentos atípicos, de mudanças econômicas e de outras contingências que podem desencadear situações muito mais complexas e críticas do que a negociação inicial.

\subsection{Especificidade do ativo}

Se um ativo empregado em determinada transação somente pode ser direcionado a outro uso com o emprego de altos custos adicionais, diz-se que ele é específico a essa transação. De acordo com Williamson (1996, p. 59), “A especificidade dos ativos se refere ao grau em que um ativo pode ser realocado a usos alternativos e por usuários alternativos, sem sacrifício do valor produtivo."13 Assim, quanto maior for a perda de valor em usos alternativos, maior é o grau de especificidade do ativo à transação em uso.

Na ECT, a especificidade de ativos é considerada como a principal dimensão em relação a qual as transações se diferem (Id., 1987, p. 52). As outras dimensões que na ótica da ECT ainda possibilitam a caracterização das transações são a frequiência e o grau de incerteza nelas envolvidas.

13 "Asset specificity has reference to the degree to which an asset can be redeployed to alternative uses and by alternative users without sacrifice of productive value." 
A especificidade de um ativo pode originar-se de diferentes formas, sendo que Williamson (1987, p. 95) considerava inicialmente quatro tipos de especificidades: do local; dos ativos físicos; dos ativos humanos (aprendizagem); e dos ativos dedicados. Mais tarde, o próprio Williamson (1996, p. 59-60) reconheceu mais duas categorias de especificidades: capital associado à marca ${ }^{14} \mathrm{e}$ especificidade temporal.

Os acordos firmados pelas empresas podem requerer investimentos, por uma ou ambas as partes, em ativos que sejam específicos à transação. No momento em que os ativos específicos são introduzidos, surge a quase-renda, definida por Milgrom e Roberts (1992, p. 602) como a parcela dos ganhos em excesso ao mínimo necessário para manter um recurso no seu uso corrente. Conforme Hill (1990, p. 501), a quase-renda gerada numa transação é a parcela de recursos que uma parte pode expropriar da outra, mas que ainda mantém esta na transação.

Nesta seção, é analisado o efeito dos investimentos específicos sobre o valor de reserva das partes numa transação. Para isso, o assunto é apresentado em duas partes distintas: especificidade inicial (seção 4.3.1) e especificidade decorrente dos investimentos promovidos (seção 4.3.2).

\subsubsection{Especificidade inicial}

Em muitas ocasiões, a transação gera rendas para um ou mais agentes nela envolvidos, ou seja, produz ganhos em excesso à quantidade mínima necessária para que o agente seja atraído a essa transação (MILGROM; ROBERTS, 1992, p. 269). ${ }^{15}$ Portanto, se o acordo for celebrado, necessariamente haverá uma quase-renda associada, já que a transação produzirá um retorno superior àquele obtido em emprego alternativo. Se tal acordo não demandar qualquer investimento para os envolvidos, o valor da quase-renda será igual ao montante das rendas obtidas.

Embora nesse caso o valor da quase-renda seja igual ao montante das rendas auferidas pelas partes, tais conceitos são distintos já que as rendas são definidas em termos de decisão de

\footnotetext{
14 "Brand name capital"

${ }^{15}$ A renda apurada pelas partes já foi tratada no capítulo 3 como excedente $(S-B)$.
} 
entrada numa indústria, ao passo que a quase-renda é definida em termos de decisão de saída (Ibid., p. 269).

O surgimento da quase-renda no momento em que os acordos são firmados é demonstrado na ilustração 3, que trata de uma negociação entre duas empresas com interesses conflitantes em torno do preço de fornecimento de um determinado produto. Sempre que o valor de reserva do comprador (B) for maior que o valor de reserva do vendedor $(S)$, haverá excedente $(B-S)$ a ser partilhado entre as partes. O próprio acordo estabelece uma especificidade inicial, independentemente de qualquer investimento ex-post. Nesse caso, conforme demonstrado na ilustração 3, a quase-renda é exatamente igual à renda ou excedente gerado na transação.

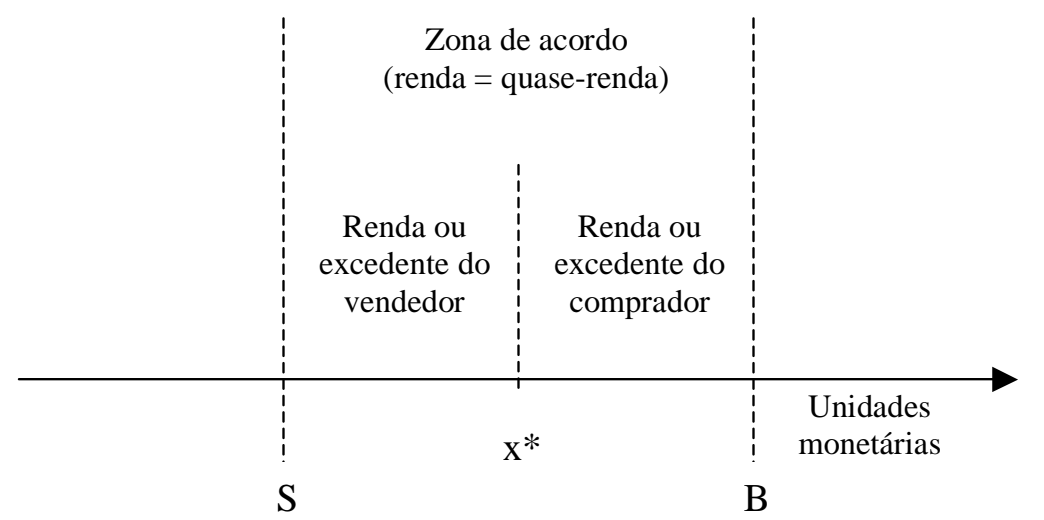

Ilustração no 3 - Excedente ou renda gerada pela transação

No momento em que a transação é celebrada, a renda obtida pelas partes $\left(\mathrm{x}^{*}-\mathrm{S}\right.$, para o vendedor; e B - $\mathrm{X}^{*}$, para o comprador) transforma-se em quase-renda, ou seja, no valor que as partes têm a perder em caso de descontinuidade do acordo. Isso significa dizer que uma vez firmado o acordo, os ativos a ele dirigidos adquirem um certo grau de especificidade.

Essa especificidade de ativos, denominada neste trabalho de especificidade inicial, surge com a celebração do acordo, e não representa maiores riscos à empresa. Mesmo que o acordo seja rompido, o que ocorre com a empresa é retornar à situação em que se encontrava antes da negociação. Em outras palavras, admitindo que não haja alterações na MAANA de cada um dos envolvidos, vendedor e comprador voltam a receber os retornos produzidos pelo melhor emprego alternativo já existente antes de firmarem o acordo. No caso em tela, havendo quebra 
contratual, o vendedor obteria S pela mercadoria, enquanto o comprador passaria a adquiri-la por B.

\subsubsection{Especificidade decorrente dos investimentos promovidos}

Nas negociações entre empresas, muitas vezes o compromisso firmado no acordo exige investimentos tais como a construção de planta industrial, a aquisição de equipamentos ou o treinamento de funcionários. Freqüentemente, esses investimentos têm algum grau de especificidade, ou seja, os ativos tangíveis e intangíveis deles decorrentes somente poderão ser realocados a usos alternativos com sacrifício do seu valor produtivo. Tais investimentos, denominados específicos, geram uma quase-renda (FARINA, 1997, p. 84), além daquela que existia inicialmente. Por exemplo, se para atender o compromisso com o cliente, o fornecedor instala uma planta industrial, provavelmente esse ativo terá alguma especificidade à transação. O grau dessa especificidade dependerá do menor valor que ele perderia ao comercializar com outro comprador, dar à planta outra finalidade ou mesmo desfazer-se do imóvel e equipamentos.

Portanto, após a realização dos investimentos específicos, se houver descontinuidade da transação, a empresa não dispõe da MAANA que existia antes da celebração do acordo. A partir do momento em que a empresa promoveu os investimentos em ativos específicos, a melhor alternativa à transação tem que incorporar os custos de saída desses ativos. Por conseguinte, em qualquer processo de renegociação com vistas à revisão do acordo, o VR da empresa também se torna menos favorável.

A ilustração 4 demonstra a redução do VR detido pelo vendedor, deslocando-se de S para S', devido ao investimento por ele promovido em ativos específicos. Caso o comprador seja o responsável pelos investimentos específicos, há o deslocamento de B para a direita. Além disso, se as duas partes investirem em ativos específicos, a zona de acordo se amplia nos dois sentidos, aumentando a dependência bilateral dos agentes.

Com a realização do investimento específico, a quase-renda passa a extrapolar as rendas originalmente obtidas pelas empresas. Isso ocorre porque a ampliação da quase-renda não implica alteração nas rendas auferidas. Na ilustração 4, pode ser constatado que a elevação da 
quase-renda significa apenas que a empresa vendedora dispõe de um VR menos favorável, caso haja uma renegociação. Nesse caso, em função da MAANA menos atraente, o vendedor tem mais a perder caso a transação seja descontinuada.

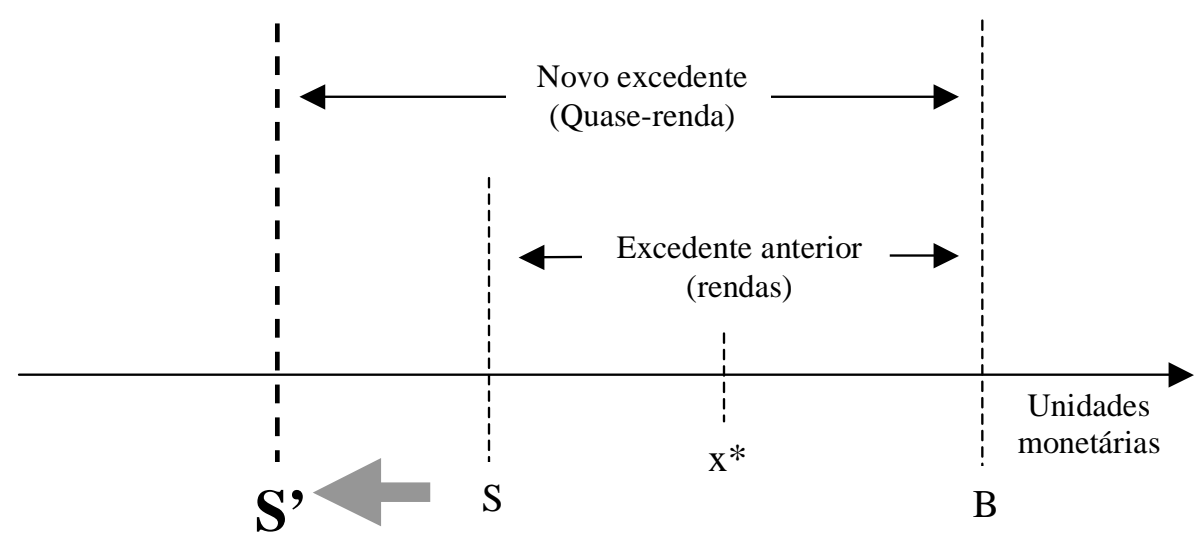

Ilustração 4 - Investimento em ativos específicos

Ocorre que é comum o surgimento de demandas por renegociação, em decorrência de os acordos serem incompletos e das constantes alterações no ambiente em que as empresas envolvidas estão inseridas. Mesmo mudanças triviais, como alterações nos níveis de preços, podem exigir revisões nos termos da transação.

Esse fato, porém, não significa necessariamente que o vendedor obterá um preço inferior a $\mathrm{x}^{*}$ na renegociação. A alteração do preço praticado depende, entre outros fatores, da informação ou percepção que as partes têm sobre os valores de reserva. Por exemplo, se o comprador não tiver conhecimento da redução de S para S', a fragilidade do vendedor não fica evidente. Para Shell (2001, p. 137), o poder de influência não depende dos fatos, e sim é baseado na percepção que as partes têm a respeito da situação. Por isso, ainda que o comprador saiba da redução de S para S', a viabilidade de empreender esforços para se aproveitar dessa redução também dependerá do conhecimento ou percepção que o vendedor tenha de B. Novamente na ilustração 4, mesmo que o comprador saiba - ou suspeite - da redução de S para S', o comprador pode não dispor de argumentos eficazes para explorar essa alteração caso o vendedor tenha conhecimento de B. Quando B é conhecido pelo vendedor, o comprador pode não conseguir promover ameaças críveis de deixar a transação. Conforme explica Shell (2001, p. 117), ameaças são efetivas somente se forem convincentes: "Caso você seja afetado, na 
mesma proporção que eles ou mais, com o cumprimento da ameaça, ela perderá a credibilidade."

Outras variáveis ainda podem interferir na definição do preço final, tais como o poder econômico dos agentes e a relevância que o negócio representa para cada uma das partes. Embora o exame dessas variáveis possa gerar uma gama de implicações refutáveis, este trabalho não explora essas questões, mas tem por propósito apenas analisar o comportamento final daquele que pode agir com oportunismo, tema que será discutido nas próximas seções.

\subsection{Oportunismo}

De acordo com Martinelli et al (2004, p. 81), o processo de negociação pode ser conduzido de forma competitiva, em que cada um dos participantes procura satisfazer a seus interesses individuais, ou cooperativa, na qual as partes buscam um acordo que proporcione a satisfação para ambos os lados. Embora seja recomendada a busca de negociações do tipo cooperativo, esses autores afirmam que nem sempre isso é possível, já que na prática prevalecem as negociações competitivas. E se uma das partes assumir uma postura competitiva, de nada adiantará a cooperação da outra. Sobre isso, Nalebuff e Brandenburger (1996, p. 14), propõem uma alternância nas posturas negociais, afirmando que "Negócio é cooperação quando o objetivo é criar um bolo e concorrência quando chega a hora de dividi-lo."

O reconhecimento da existência de tais estilos de negociação, contudo, muitas vezes não é o bastante para quem está negociando, pois classificar a contraparte pode ser uma tarefa espinhosa, especialmente quando não há histórico de negociações passadas. Além da possibilidade de não haver histórico suficiente para proceder a determinado julgamento, o outro lado pode agir com dolo, escondendo suas reais intenções. A própria postura das partes pode se alterar, principalmente no caso de negociações entre organizações econômicas, já que estas passam por reformulações na diretoria e presidência, ou simplesmente têm suas estratégias revistas. Também é possível que a alteração do ambiente no qual as empresas estão inseridas demande mudanças comportamentais, muitas vezes fazendo com que a cooperação inicial seja substituída por uma postura mais competitiva. Essas alterações no comportamento 
das partes, entretanto, podem afetar não somente as negociações que antecipam a elaboração do acordo, mas principalmente o próprio cumprimento dos termos acordados.

Conforme já mencionado, em decorrência da racionalidade limitada, os agentes não prevêem todas as contingências possíveis, e os acordos são incompletos. Como eventuais revisões do acordo tornam necessária a realização de renegociações, as empresas novamente precisam atentar ao seu VR, bem como à distribuição de probabilidade do VR detido pela outra parte. No entanto, o VR não permanece imutável quando são promovidos investimentos específicos. Pelo contrário, o poder de negociação da empresa que investiu em ativos específicos fica comprometido justamente em função da alteração do VR, seja a redução de $S$ ou a elevação de B.

Nessas situações, depois que o investimento específico é promovido e que quase-rendas são criadas, a possibilidade do comportamento oportunista é muito real (KLEIN et al, 1978, p. 298). Mesmo quando todas as contingências relevantes possam ser especificadas, os contratos ainda estarão abertos a sérios riscos em decorrência do oportunismo (Ibid., p. 297). Em face disso, a ECT apresenta o oportunismo como um pressuposto comportamental dos agentes humanos (WILLIAMSON, 1987, p. 30).

Para Williamson (1987, p. 47), o oportunismo implica a busca de interesse próprio com dolo, incluindo algumas formas mais flagrantes tais como a mentira, o roubo, o engano, mas não limitadas a elas. Entendendo que o oportunismo amiúde compreende algumas formas sutis de engano, como a revelação incompleta ou distorcida da informação, Williamson ainda afirma que:

Em termos mais gerais, o oportunismo se refere à revelação incompleta ou distorcida da informação, especialmente aos esforços premeditados para equivocar, distorcer, ocultar, ofuscar ou confundir de outro modo. O oportunismo é responsável pelas condições reais ou aparentes de assimetria da informação que complicam enormemente os problemas da organização econômica. Tanto as principais como as terceiras partes (árbitros, tribunais, etc.) afrontam problemas muito mais difíceis de inferência ex-post como conseqüência. ${ }^{16}$ (Ibid., p. 47-48).

\footnotetext{
16 "More generally, opportunism refers to the incomplete or distorted disclosure of information, especially to calculated efforts to mislead, distort, disguise, or otherwise confuse. It is responsible for real or contrived conditions of information asymmetry, which vastly complicate problems of economic organization. Both principals and third parties (arbitrators, courts, and the like) confront much more difficult ex post inference problems as a consequence."
} 
O denominado comportamento oportunista, contudo, não se confunde com a já comentada postura competitiva. $\mathrm{O}$ negociador competitivo, adepto do ganha-perde, emprega meios para tirar vantagens do outro na confecção do acordo. Sua intenção é que o acordo lhe seja o mais favorável possível. Já no oportunismo, o indivíduo pode agir com auto-interesse antes ou mesmo após a celebração do acordo.

Conforme assinalam Farina et al (1997, p. 78), existem duas formas de comportamento oportunista, distinguidas temporalmente:

a) Ex-ante - em que uma parte age aeticamente, antes de se efetivar a transação.

b) Ex-post-em que o comportamento aético se verifica durante a vigência do contrato.

Parte do comportamento oportunista decorre da assimetria de informação, ocasionando problemas de seleção adversa (ex-ante) e risco moral (ex-post). Enquanto na seleção adversa, somente uma das partes detém a informação que a beneficiará em detrimento do outro lado; no risco moral, uma das partes, mesmo que inicialmente adotando uma postura cooperativa até a elaboração do acordo, pode se aproveitar de mudanças exógenas não previstas no contrato, redirecionando seu comportamento, em prejuízo do outro lado. É importante destacar que o risco moral se revela de duas formas: a informação oculta, quando o agente adquire alguma informação que o principal não tem; e a ação oculta, quando o esforço do agente não pode ser observado.

No entanto, segundo Williamson (1993, p. 101), o oportunismo não se limita aos aspectos relacionados com a disponibilidade de informação entre as partes, mas admite até mesmo a possibilidade de os agentes mentirem, trapacearem e roubarem. Ainda conforme o autor, é possível que os agentes ajam em conformidade com o que foi escrito, mas violando o espírito do acordo.

Embora adote o oportunismo como pressuposto comportamental dos agentes, a ECT não quer com isso propor que todos os agentes se comportem a maior parte do tempo com oportunismo (Ibid., p. 98). De acordo com Farina et al (1997, p. 79), o comportamento humano oportunista não precisa necessariamente estar presente em todos os indivíduos, nem tampouco é necessário que cada indivíduo se porte de forma oportunista o tempo todo. Basta existir a possibilidade de uma ação oportunista para que se justifique a inclusão de salvaguardas 
contratuais a fim de amenizar eventuais danos. Nessa linha, Williamson (1987, p. 64) assume “[...] meramente [...] que alguns indivíduos são oportunistas parte do tempo e que a confiabilidade diferencial é raramente transparente ex-ante." 17

Com isso, admitindo que as pessoas são limitadamente racionais e oportunistas, a ECT propõe que o agente responsável pelos investimentos específicos se coloca numa posição de refém da transação, possibilitando que a contraparte empregue a pilhagem. ${ }^{18}$ Se a contraparte agir de maneira oportunista, o agente responsável pelos investimentos específicos pode apurar, tal como foi demonstrado na seção 4.3.2, um ganho menor do que o proporcionado pelo VR por ele detido antes de entrar na transação. ${ }^{19}$

Ainda de acordo com a proposta da ECT, se não houvesse oportunismo, todo comportamento poderia ser governado por promessas, com cada uma das partes se comprometendo ex-ante a buscar somente os rendimentos justos nos intervalos de renovação do contrato (Ibid., p. 31). Com isso, eventos não previstos em razão da racionalidade limitada seriam facilmente resolvidos já que as partes aceitariam limitar suas ações a fim de permitir a maximização conjunta dos benefícios. De outra forma, se o cumprimento das promessas pudesse ser assegurado, não haveria problemas de má-adaptação ex-post (Id., 1993, p. 97).

\subsection{Restrições ao comportamento oportunista}

Apesar de existir uma clara distinção entre a intenção do agente e o comportamento por ele empregado, Ghoshal e Moran (1996, p. 19) acreditam que essa nuance não mereceu atenção na obra de Williamson. Conforme sustentado por Ghoshal e Moran, o oportunismo pode ser conceituado como atitude, inclinação ou propensão a agir oportunisticamente, enquanto o comportamento oportunista constitui a manifestação material do oportunismo. Dessa maneira, esses autores enfatizam a diferença entre a intenção oportunista do agente, doravante tratada como "oportunismo", e a sua manifestação comportamental, denominada doravante de

\footnotetext{
17 “[...] merely [...] that some individuals are opportunistic some of the time and that differential trustworthiness is rarely transparent ex ante."

18 A palavra pilhagem está sendo empregada como uma tradução livre de "hold-up", termo empregado pelos teóricos da ECT para retratar a expropriação - ou tentativa de expropriação - das quase-rendas.

${ }^{19}$ Para a ECT, as transações que exigem um alto grau de investimento específico tendem a serem integradas dentro da firma (WILLIAMSON, 1987, p. 78), já que as partes reconhecem ex-ante a incompletude contratual.
} 
“comportamento oportunista". Ainda sobre essa distinção, releva notar que a presença do oportunismo influencia, mas não é aspecto determinante para a ocorrência do comportamento oportunista, já que as pessoas com intencionalidade oportunista podem não agir oportunisticamente, em razão de suas percepções das recompensas e punições associadas às diferentes posturas. ${ }^{20}$

Reconhecendo a existência desses diferentes conceitos, é possível encontrar duas razões para a ocorrência de um comportamento colaborativo ou não-oportunista: a existência de restrições concretas ou potenciais para a prática do comportamento oportunista, o que independe da intenção do agente; e a própria intencionalidade não oportunista do agente. Entre as restrições ao comportamento oportunista, tratadas no item 4.5.1, podem ser destacadas as próprias cláusulas e sanções contratuais, a freqüência das transações e a necessidade de desenvolver reputação. No aspecto relativo à intencionalidade não oportunista, apresentado no item 4.5.2, é fundamental que se reconheça o efeito da norma da reciprocidade. Por fim, algumas evidências empíricas do comportamento dos agentes são apresentadas na seção 4.5.3.

\subsubsection{Sanções contratuais, freqüência das transações e reputação.}

Nesta seção, são apresentadas algumas formas de punição que podem levar os indivíduos a não adotarem o comportamento oportunista. Enquanto algumas punições são previstas no próprio contrato ou dele decorrem, outras somente serão imputadas em transações futuras. Naturalmente, as cláusulas contratuais não são suficientes para evitar todo e qualquer comportamento oportunista, em função da racionalidade limitada. Por vezes, uma das partes pode se comportar oportunisticamente porque não foi prevista uma punição a esse comportamento; em outras ocasiões, o comportamento oportunista ocorre porque os ganhos com ele auferidos excedem as perdas impostas pelo contrato.

No tocante às perdas imputadas em futuras transações, as partes fundamentalmente poderão ter o comportamento oportunista restringido pela freqüência das transações ou pela necessidade de desenvolver reputação. Nesse sentido, Hill (1990, p. 505) afirma que a eficácia

\footnotetext{
${ }^{20}$ Naturalmente, assim como existe a possibilidade de punições e recompensas inibirem o comportamento oportunista, é possível que determinados ambientes estimulem esse comportamento. Por exemplo, se enganar o comprador for regra entre os vendedores, aquele que não o fizer poderá ser punido pelos iguais. Logo, existiria punição para o agente que não adotasse o comportamento oportunista.
} 
na eliminação do comportamento oportunista depende das incertezas dos agentes quanto à ocorrência de transações futuras. Se houver uma única transação envolvendo os agentes, ou se o número de transações for finito e previamente definido, os agentes podem enxergar o comportamento oportunista como uma estratégia viável. No entanto, se houver incerteza quanto às transações futuras e pressupondo a existência de punição ao agente que se comportou de maneira oportunista, o negociador depara com restrições a tal comportamento.

Acontece que Hill acredita que sempre haverá incertezas quanto a novas transações:

Num mundo em que a única constante é a mudança, o futuro é incognoscível. Contudo, parece evidente que, na maioria das trocas, ambas as partes entrem com a expectativa de que podem se interagir novamente no futuro, embora nenhuma delas possa predizer ou saber exatamente quantas vezes isso ocorrerá. ${ }^{21}$ (Ibid., 505).

De maneira similar, os economistas têm apontado que um dos incentivos a não se comportar de maneira oportunista é o efeito negativo à reputação do agente (GRANOVETTER, 1985, p. 490). Assim, desde que o comportamento indesejado seja visível após as transações, e que potenciais participantes em transações futuras obtenham informações relativas a transações prévias, o efeito das reputações sugere que o resultado esperado das transações seja idêntico ao de uma série infinita de transações futuras.

\subsubsection{Intencionalidade não oportunista}

Independentemente do efeito das restrições tratadas na seção anterior, é esperado que o comportamento oportunista não se manifeste caso o indivíduo não tenha a intencionalidade de praticá-lo. Nesse caso, o próprio agente pode não se guiar pelo oportunismo. Pelo contrário, num contexto em que um dos lados depositou confiança no outro, promovendo os investimentos específicos à transação por eles celebrada, alguns autores acreditam que a parte beneficiada poderia inclusive recompensar a decisão de promover tais investimentos. Consoante sustentam Fehr e Gächter (2000, p. 161), existe uma norma de reciprocidade, já que a concessão inicial gera em muitas pessoas um débito psicológico.

21 "In a world in which the only constant is change, the future is unknowable. However, it seems evident that across a majority of exchanges both parties enter with the expectation that they may interact again in the future, although neither party can predict or know exactly how many times this will occur." 
Para Gouldner (1961, p. 171) a norma da reciprocidade significa deveres que as pessoas têm para com os outros, não como seres humanos, membros de grupos ou ocupantes de uma posição social na sociedade, mas sim por suas atitudes anteriores. Nesse sentido, Shell (2001, p. 72) afirma que "Devemos determinadas coisas aos outros em razão do que já tenham feito anteriormente por nós, devido à história de interações passadas que tivemos com eles." Fehr e Gächter (2000, p. 159) também abordam o assunto, dizendo que muitas pessoas desviam-se do comportamento auto-interessado, e agem de maneira recíproca. Por reciprocidade, os autores entendem que em resposta a ações amistosas, as pessoas serão mais vezes e mais amplamente cooperativas do que as previstas em modelos baseados no auto-interesse.

Ainda segundo Fehr e Gächter, há considerável evidência que substancial fração das pessoas recompensem presentes e se vinguem das ofensas, mesmo em suas interações com estranhos e ainda que isso represente um custo presente sem qualquer expectativa de recompensa material no futuro. ${ }^{22}$ Sobre o assunto, Hill (1990, p. 502) assinala que mesmo quando a especificidade de ativos é alta, existem agentes que, por razões de princípio, nunca serão os primeiros a agir de maneira oportunista.

Embora Gouldner (1961, p. 171) sugira que a norma da reciprocidade seja universal, ele afirma que ela não é incondicional. Antes, a ação recíproca é influenciada, entre outras coisas, pelo grau de necessidade de retribuição daquele que inicialmente promoveu "a boa ação" e pela disponibilidade de recursos daquele que pretende agir reciprocamente. Além disso, o autor ainda afirma que a reciprocidade terá diferentes funções em diferentes culturas. Conforme sustenta Granovetter (1985, p. 502), as relações entre os agentes econômicos dependem do contexto social em que esses agentes se inserem. Portanto, o envolvimento pessoal dos dirigentes e funcionários de diferentes empresas pode condicionar a presença e o grau do comportamento oportunista entre essas empresas.

\subsubsection{Evidências empíricas}

As questões envolvendo reciprocidade ou oportunismo têm merecido a atenção de muitos trabalhos empíricos, entre os quais destaca-se o experimento denominado "jogo da

${ }^{22}$ De acordo com Fehr e Gächter (2000, p. 162), parece inclusive surgir um consenso entre os pesquisadores de que a propensão a punir o comportamento prejudicial é mais intensa do que a propensão a premiar o comportamento favorável. 
confiança". ${ }^{23}$ Nesse experimento, os participantes são divididos em pares, sendo que um deles, denominado remetente, recebe uma quantidade monetária " $\mathrm{x}$ " e deve enviar entre zero e " $\mathrm{x}$ ” para o outro, chamado de destinatário. Depois que a quantia é enviada, esse valor é majorado, por meio da multiplicação por algum número "n". O destinatário então escolhe o valor - entre zero e o produto de "x" e " $n$ " - que devolverá ao remetente. Enquanto o montante enviado é uma medida do nível de confiança que os indivíduos depositaram nos seus pares, o valor devolvido mensura o quão recíproco foram os agentes participantes do experimento.

De maneira geral, analisando uma série desses experimentos, Fehr e Gächter (2000, p. 162) constataram que entre $40 \%$ e $66 \%$ dos indivíduos se comportaram de maneira recíproca. Por outro lado, esses mesmos estudos revelaram que entre $20 \%$ e $30 \%$ dos participantes não se guiaram pelas normas da reciprocidade, comportando-se de maneira completamente egoísta.

Aplicando o jogo da confiança com estudantes de graduação da Harvard University, Glaeser et al (2000) permitiram que os participantes soubessem previamente quem era o seu par. No entanto, eles não puderam se comunicar enquanto decidiam sobre o montante enviado ou retornado. A aplicação desse experimento revelou alguns padrões de comportamento: a confiança e a reciprocidade foram maiores em indivíduos socialmente próximos; ${ }^{24}$ houve menor grau de reciprocidade entre participantes de diferentes raças ou nacionalidades; e indivíduos com alto status ${ }^{25}$ receberam maiores retornos, indicando que foram tratados de forma mais recíproca que os demais (Ibid., p. 814).

Pode-se afirmar que a análise do comportamento oportunista é mais complexa nas situações em que a pilhagem é possível em razão do investimento em ativos específicos. Isso porque a ação favorável ao destinatário é inequívoca no jogo da confiança, mas é menos evidente na decisão de promover investimentos específicos. Mesmo que o agente reconheça a confiança nele depositada por conta dos investimentos específicos promovidos pela contraparte, um desentendimento futuro pode envenenar todo o relacionamento existente.

\footnotetext{
23 "Trust game"

${ }^{24}$ Os autores mediram essa proximidade de acordo com a conexão social, a qual envolveu o número de amigos em comum e a duração da amizade.

${ }^{25}$ Pessoas com pais com maior grau de educação, estudantes que trabalham menos horas por período, indivíduos com mais amigos, e membros de organizações voluntárias.
} 
Conforme Hackett (1994, p. 361), surpreendentemente são poucos os trabalhos experimentais orientados para o problema da barganha em situações de contratos incompletos com especificidade de ativos. Visando capturar parte do efeito dos investimentos específicos, o autor promoveu um experimento em que os participantes foram divididos em pares de negociação, interagindo em dois estágios: investimento em ativos específicos e barganha do excedente gerado na transação. ${ }^{26}$

Nesse estudo, em que ambos os lados necessitavam definir antecipadamente o grau de investimentos específicos, o pesquisador optou por isolar os participantes para que pudesse garantir o anonimato e inibir efeitos da reputação e da freqüência dos contratos repetitivos. A realização do exercício por meio de computadores também evitou que os agentes combinassem o procedimento a ser adotado no segundo estágio. Os resultados da pesquisa revelaram fortes evidências de que podem ser criadas associações entre os investimentos em custos irrecuperáveis e a divisão ex-post dos excedentes em relações contratuais, mesmo na ausência dos efeitos da reputação individual e da frequiência contratual (Ibid., p. 383). A condição de anonimato, entretanto, impediu que pudessem ser exploradas as associações entre o comportamento oportunista e características dos participantes envolvidos.

\footnotetext{
${ }^{26}$ Devido à utilização de computadores, os negociadores mantiveram-se no anonimato em todo o experimento. No primeiro estágio do experimento, cada participante decidia isoladamente o nível de investimento que promoveria em ativos específicos à transação. No outro estágio, os participantes conheciam o resultado total que a transação proporcionaria e poderiam ratificá-la, barganhando a distribuição do excedente. O resultado global gerado pela transação dependia dos investimentos específicos, mas não era exclusivamente determinado por eles. Caso optassem pela negociação, um dos sujeitos informava a regra de distribuição do excedente (porcentagem devida a cada um) enquanto o outro registrava sua aceitação ou veto. Se houvesse reprovação, havia uma probabilidade $\delta$, conhecida por ambos, de a negociação fracassar, o que significava não haver excedente para ser dividido. Conseqüentemente, havia uma probabilidade de $1-\delta$ de a barganha continuar. Em caso de continuidade, aquele que reprovou a oferta poderia submeter uma nova regra ao outro. A barganha tinha seqüência até que ocorresse o fracasso ou aceitação da regra sugerida. Os pares de negociação podiam ser divididos em quatro grupos, em função das variações nas regras fornecidas aos pares. As diferentes regras decorriam de alterações em $\delta(0,1$ ou 0,67$)$ e no conhecimento do valor investido pela contraparte no primeiro estágio (sim ou não).
} 


\title{
5 PROBLEMA DE PESQUISA
}

O que de fato ocorre depois que os investimentos específicos são promovidos é uma alteração no poder de negociação, fato inclusive descrito por Raiffa (1982, p. 195), ao comentar sobre o investimento promovido por empresas multinacionais em países em desenvolvimento:

\begin{abstract}
Nas etapas iniciais de negociação, uma companhia internacional tem uma carta de negociação forte: facilmente pode se recusar a investir. Mas uma vez que realiza um investimento de porte, o poder de negociação da companhia se dissipa gradualmente; converte-se em refém de seus próprios custos incorridos, e o poder de regateio desloca-se em favor do país anfitrião. Ambas as partes sabem disso de antemão, e se é a antecipação desta probabilidade que está impedindo o convênio, então pode ser do interesse das duas partes tentar fazer com que os contratos inseguros sejam mais seguros. ${ }^{27}$
\end{abstract}

Essa pretensão de se construir um contrato mais seguro, porém, encontra empecilho nos já comentados limites da racionalidade. Em face de os indivíduos possuírem racionalidade limitada, os acordos são incompletos e sempre haverá contingências, sujeitando as partes à renegociação.

Mesmo quando as partes detêm conhecimento dos riscos a que se expõem, é extremamente complexo prever todas as contingências possíveis. No contrato celebrado entre General Motors e Fisher Body em 1919, exemplo recorrentemente abordado pela ECT, as partes reconheceram ex-ante a necessidade da criação de salvaguardas relativas à exclusividade, à duração contratual e ao preço de fornecimento, para incentivar a Fisher Body a promover os investimentos específicos à transação (KLEIN et at., 1978, p. 308-309). A General Motors concordou em adquirir carrocerias exclusivamente da Fisher, por um período de dez anos. Adicionalmente, as empresas fixaram um preço atrelado aos custos variáveis de produção enfrentados pela Fisher. Entretanto, a própria inclusão de salvaguardas deu causa ao comportamento oportunista da Fisher Body. Com o aumento da quantidade demandada muito acima do previsto, o preço poderia ser reduzido em razão da elevação do produto por unidade de capital empregado. Contudo, o contrato vedava uma eventual renegociação dos preços, portanto beneficiando a Fisher.

\footnotetext{
27 "In the initial stages of negotiation, an international company has a strong bargaining chip: it simply can refuse to invest. But once a large investment takes place, the company's bargaining power gradually dissipates; it becomes hostage to its own sunk costs, and the bargaining power shifts to the host country. Both parties know this in advance, and if it is the anticipation of this possibility that is preventing agreement, then it may be in the interest of both sides to try to make these insecure contracts more secure."
} 
Nesse exemplo, em razão das salvaguardas, a empresa que investiu em ativos específicos pôde agir de maneira oportunista. Existem, inclusive, outras situações em que o comportamento oportunista pode ser empreendido pela parte que promoveu os investimentos específicos (Ibid., 300). No entanto, a preocupação fundamental deste trabalho diz respeito ao comportamento oportunista empregado para a expropriação das quase-rendas que antes eram obtidas pelo agente que promoveu os investimentos específicos. Portanto, o problema de pesquisa a que se propõe este trabalho é descobrir:

\section{“Que comportamento - oportunista ou não oportunista - os agentes manifestam nas renegociações quando seu poder relativo de negociação aumenta em razão dos investimentos específicos promovidos pela contraparte?"}

Ora, com os investimentos específicos alterando o VR, aqueles que promoveram tais investimentos normalmente tornam-se reféns da transação e, portanto, sujeitos a serem pilhados pela contraparte. Nessas renegociações, entretanto, existem duas visões praticamente opostas a respeito da motivação pela qual se guia a contraparte: oportunismo ou reciprocidade. A contraparte pode ter a intenção de expropriar as quase-rendas ou pode ter a intenção de premiar o comportamento empregado no momento anterior. Além disso, conforme já foi discutido neste trabalho, o agente que se guia pelo oportunismo - ou pela intenção oportunista - não necessariamente adota uma postura oportunista, já que esse comportamento pode ser atenuado em razão das salvaguardas e da expectativa quanto à ocorrência de novas transações.

Conhecer o comportamento que prevalecerá nessas situações é um desafio para o negociador, assim como para aqueles que pretendem construir uma teoria de negociação com conteúdo preditivo, dotado de hipóteses testáveis. Essa questão é de fundamental interesse para os analistas de negociação e, principalmente, para os negociadores que necessitam promover investimentos não triviais em ativos específicos. Além de ser necessário descobrir como o outro lado se comporta, igualmente importante é explorar em que condições o outro lado age ou não de maneira oportunista.

O tema tem sua relevância garantida em face de que as transações recorrentes e os acordos com efeitos que persistem no tempo são cada vez mais a regra entre as empresas. Além disso, 
freqüentemente são elaborados acordos complexos, exigindo investimentos específicos por uma ou mais partes envolvidas. Dessa maneira, com a alteração no VR de um dos lados, surgem oportunidades para que a contraparte se comporte de maneira oportunista. Neste trabalho, procura-se justamente descobrir se a contraparte emprega ou não a pilhagem nessas situações. Para isso, o próximo capítulo apresenta a metodologia empregada para responder ao problema de pesquisa proposto. 


\section{METODOLOGIA}

\subsection{Os experimentos em laboratório}

As interações reais seriam uma fonte praticamente inesgotável de pesquisas caso fosse possível conhecer os valores de reserva dos agentes envolvidos. Contudo, é natural que as partes busquem se proteger, omitindo seus limites. Assim, as pesquisas no complexo mundo real são prejudicadas em razão da dificuldade de se obter o verdadeiro VR das partes, mesmo depois de concluídas as negociações (RAIFFA, 1982, p. 59). Segundo Raiffa (2002, p. 273), no mundo real, os negociadores são avaliados primeiramente em sua habilidade para atingir acordos viáveis, e ninguém sabe se ganhos potenciais foram deixados sobre a mesa. Além disso, alguns negociadores tampouco detêm preços reservados firmes (Ibid., p. 111).

Diante desses empecilhos para a coleta de informações nas transações reais, optou-se por simular negociações experimentais no formato de interações entre duas pessoas. Basicamente, um experimento "[...] consiste na construção de uma situação artificial que simula certos aspectos do mundo real.” (BIANCHI; SILVA FILHO, 2001, p. 139). Com essa simulação da realidade, Cooper e Schindler (2003, p. 321) acreditam que a pesquisa experimental permite o controle de variáveis estranhas de forma mais eficaz do que outros métodos de pesquisa, além de permitir a repetição de determinadas situações com diferentes participantes. Por outro lado, Bianchi e Silva Filho (2001, p. 140) enfatizam que vários economistas contemporâneos questionam a validade dos experimentos, por entenderem que os indivíduos exibem um comportamento diferente daquele que adotariam no mundo real. Para os críticos desse método de pesquisa, os experimentos freqüentemente não permitem a aprendizagem e adaptação. Outro inconveniente seria o fato de os indivíduos poderem alterar seu comportamento em razão de saberem que estão sendo observados.

No caso particular do campo das negociações, a realização de simulações em laboratório surge como alternativa ao pesquisador, pois a ele permite não somente conhecer os valores de reserva dos participantes, como também manipular o ambiente e as regras da negociação, a fim de que se obtenha a situação desejada para testar o problema de seu interesse. Conforme 
enfatizam Cooper e Schindler (2003, p. 320), um experimento possibilita que o pesquisador altere sistematicamente as variáveis de interesse, de modo a observar as mudanças ocorridas.

\subsection{Procedimentos preliminares}

Os agentes do experimento foram alunos da Universidade de São Paulo matriculados na disciplina Modelos de Negociação, oferecida em duas turmas à graduação em Administração, no primeiro semestre de 2005, pela Faculdade de Economia, Administração e Contabilidade. O laboratório foi realizado em seção única, no dia 29.3.2005, agrupando essas duas turmas. Com isso, participaram do experimento 176 alunos, distribuídos em 88 pares de negociação, cada qual formado por um investidor e um comprador. As interações foram no formato facea-face, e as partes puderam negociar livremente, sendo que a única restrição imposta foi o tempo disponível para as negociações. A formação dos pares foi aleatória, não havendo controle sobre as variáveis independentes, como a idade, sexo e conhecimento prévio entre os integrantes do mesmo par de negociação.

O experimento envolveu duas etapas ou estágios de negociação, o que permitiu a comparação entre o resultados apurados em cada uma dessas negociações. Como forma de estímulo para que os participantes simulassem o comportamento real, o experimento concedeu uma bonificação a todos os participantes na prova da mencionada disciplina. Foi informado previamente aos negociadores que a bonificação a ser auferida pelo aluno dependeria do resultado por ele obtido nas negociações com a contraparte.

Para que o experimento permitisse a análise pretendida, optou-se por solicitar de apenas um dos envolvidos o investimento em ativos específicos. Dessa forma, desde que esse participante decidisse promover tais investimentos na primeira etapa, existiriam na renegociação dois papéis distintos: um participante com um VR menos favorável do que o detido na etapa precedente; e outro que poderia ou não empregar a pilhagem do primeiro.

Pode ser afirmado que, normalmente, as pessoas e as empresas sabem com quem estão negociando, trocam informações e estabelecem compromissos por confiar uns nos outros. A própria maneira pela qual o negociador se comunica pode afetar as decisões da contraparte, já 
que é possível influir na estruturação das questões e até mesmo formular ameaças e promessas, ainda que não sejam críveis. Por tudo isso, a negociação celebrada na primeira etapa pode influenciar o comportamento na renegociação, depois que os ativos específicos já foram promovidos. Em razão desses aspectos, optou-se por estabelecer negociações livres, em que as partes pudessem interagir face-a-face, sem qualquer mecanismo condutor.

\subsection{Primeira rodada de negociação}

$\mathrm{Na}$ primeira etapa, as partes negociaram o preço pelo qual determinado bem seria transacionado. No entanto, para que a transação fosse concretizada, um dos alunos precisava promover investimentos em ativos específicos à transação. A todos os participantes, foi

entregue um formulário ${ }^{28}$ com as instruções iniciais, detalhando os objetivos da negociação e o papel de cada negociador:

a) Investidor - precisava decidir nessa primeira etapa se construiria ou não uma fábrica de plástico na cidade de Araguari (MG), com capacidade de produzir um lote de plástico por ano. Paralelamente a isso, poderia negociar com o comprador o preço de fornecimento do lote de plástico para o primeiro ano $\left(\mathrm{P}_{1}\right)$;

b) Comprador - possuía uma fábrica de brinquedos na cidade de Araguari (MG), e utilizava um lote de plástico por ano como matéria-prima. Nessa primeira etapa, necessitava adquirir o lote anual. Sendo assim, poderia comprá-lo de um produtor estrangeiro por $\$$ 85; ou do investidor, caso este decidisse construir a fábrica de plástico. Os participantes foram explicitamente informados de que o preço cobrado pelo produtor estrangeiro poderia oscilar de um ano para outro.

Para a construção da fábrica, o investidor despenderia uma quantia que no mercado financeiro lhe renderia \$ 45 ao ano. Tendo em conta que o custo de fabricação do lote era $\$ 15$, o VR para a venda do lote de plástico na primeira rodada era igual a $\$ 60$. Esse valor foi explicitamente informado nas instruções iniciais a fim de facilitar o perfeito conhecimento do VR detido pelo investidor nessa primeira rodada de negociação. ${ }^{29}$ Os integrantes de cada par de negociação deveriam estabelecer conversações para decidir se pactuariam um acordo de

${ }^{28}$ Ver Apêndice 1.

${ }^{29}$ O VR igual a \$ 60 é obtido com somatório do custo de fabricação (\$15) com o custo de oportunidade (\$ 45). 
fornecimento para o lote de plástico, bem como, se houvesse esse acordo, definir qual seria o preço do lote para o primeiro ano $\left(\mathrm{P}_{1}\right)$. As negociações eram livres, mas era vedada a comunicação entre componentes de diferentes pares. Além disso, outra restrição foi o tempo disponível para a negociação, fixado em 15 minutos.

Com as informações disponíveis, a zona de acordo dos negociadores poderia ser facilmente traçada, conforme demonstrado na ilustração 5. Visto que a informação era completa nesse primeiro estágio, esperava-se que todos os pares que alcançassem um consenso, pactuassem um preço compreendido entre o valor de reserva do investidor $\left(S_{1}=60\right)$ e o valor de reserva do comprador $\left(\mathrm{B}_{1}=85\right)$. Em outras palavras, $\mathrm{P}_{1}$ deveria se localizar em algum ponto da zona de acordo $\left(60 \leq \mathrm{P}_{1} \leq 85\right)$.

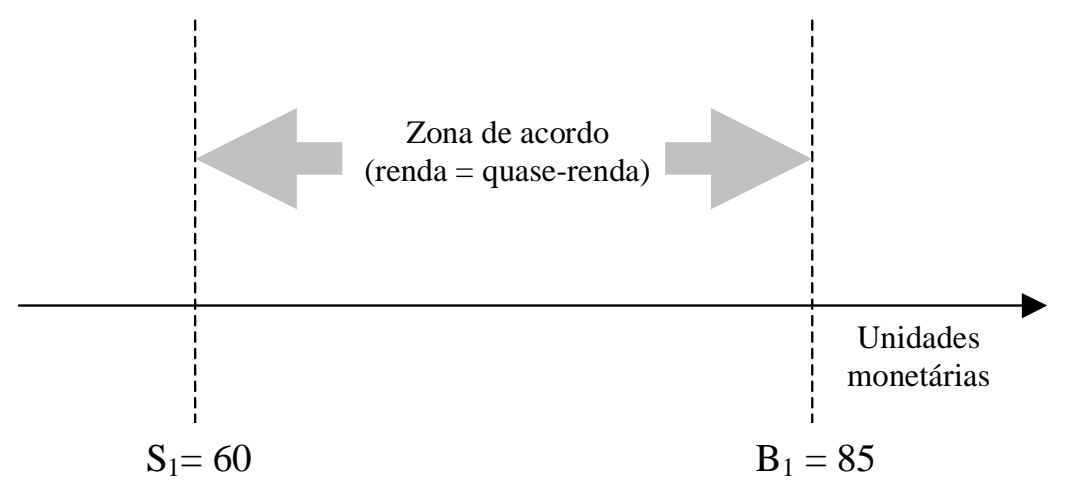

Ilustração $n^{0} 5$ - Zona de acordo na primeira rodada

Os participantes também foram informados de que existiam outros compradores alternativos para o lote de plástico, localizados no ABC Paulista, distante 720 Km de Araguari (MG). Em função do preço do frete, caso o investidor optasse por vender o lote para tais empresas, receberia apenas $\$ 35$. Obviamente, não fazia sentido construir a fábrica em Araguari para vender o lote de plástico às empresas do $\mathrm{ABC}$ Paulista. Essa alternativa somente era informada a fim de que os participantes pudessem prever a possibilidade de redução de $\mathrm{S}$ na segunda etapa do experimento.

Naturalmente, poderia ser esperado que o investidor analisasse não somente o retorno financeiro de curto prazo, mas também a incerteza envolvida no investimento. Dessa maneira, em última análise, a decisão pela construção da fábrica poderia ser vista como um voto de confiança no comprador. Por outro lado, como não havia garantias de que o comprador 
reconheceria a confiança empenhada e recompensaria o investidor no futuro, existia a possibilidade de não haver acordo na maior parte dos pares, comprometendo inclusive o objetivo da pesquisa.

Em razão de o experimento não ter por objetivo analisar a decisão dos investimentos ex-ante, mas sim o que ocorreria depois que os investimentos específicos fossem promovidos, optouse por incentivar, de maneira sutil, a decisão de promover os investimentos. Assim, os participantes foram informados de que os pares que não chegassem a um acordo seriam dispensados da etapa posterior. ${ }^{30}$

\subsection{Segunda rodada de negociação}

Depois de concluídas as negociações e de dispensados os pares que não estabeleceram um acordo na etapa precedente, foi distribuído um novo formulário ${ }^{31}$ com as instruções relativas à segunda etapa de negociação. Por meio desse formulário, os participantes foram informados de que o custo de fabricação do lote continuaria $\$ 15$ e de que as empresas localizadas no ABC Paulista continuariam pagando $\$ 35$ pelo lote de plástico.

Nessa etapa, não foram demandadas decisões de investimentos, pois os participantes precisavam apenas negociar o preço do lote de plástico para o segundo ano. Como o investidor já havia construído a planta industrial na primeira rodada, não dispunha da alternativa de aplicar seus recursos no mercado financeiro. Isso significa que houve alteração no VR detido pelo investidor, de $S_{1}=\$ 60$ para $S_{2}=\$ 35$. O formulário também sinalizou a introdução de assimetria de informação: os participantes foram comunicados de que o preço pelo qual o produtor estrangeiro se dispunha a comercializar seria revelado em envelope confidencial $^{32}$ somente ao comprador.

\footnotetext{
${ }^{30}$ Os participantes sabiam que a bonificação individual seria atrelada ao desempenho, mas não tinham informações para calcular o seu ganho ou lucro na rodada seguinte. No caso do comprador, ele sabia que o preço cobrado pelo produtor estrangeiro poderia ser outro. Para o investidor, em nenhum momento foi informado se haveria alteração no rendimento proporcionado pelo mercado financeiro. Para efeito de cálculo da bonificação daqueles que não lograram o acordo na primeira etapa, admitiu-se que o investidor manteve seus recursos aplicados no mercado financeiro, rendendo \$ 45 ao ano, e que o comprador permaneceu adquirindo o lote de plástico do produtor estrangeiro por $\$ 85$.

${ }^{31}$ Ver Apêndice 2.

${ }^{32}$ Ver Apêndice 3.
} 
Assim, após a leitura dessas instruções, foi distribuído o mencionado envelope, por meio do qual o comprador soube que o produtor estrangeiro continuava cobrando $\$ 85$ pelo lote. ${ }^{33}$ Uma vez que as partes precisavam negociar um novo preço para o lote de plástico $\left(\mathrm{P}_{2}\right)$, e considerando que o valor de reserva do comprador $\left(\mathrm{B}_{2}\right)$ mantinha-se igual ao da etapa precedente $\left(\mathrm{B}_{1}\right)$, a nova zona de acordo, na forma da ilustração 6 , somente era plenamente conhecida pelo comprador.

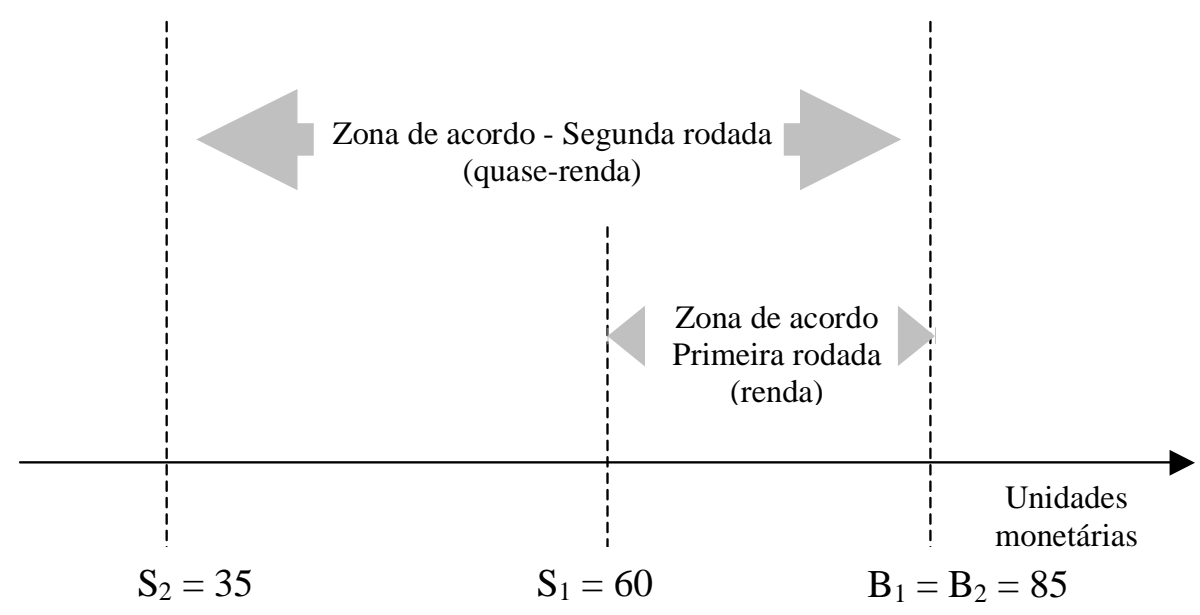

Ilustração $\mathrm{n}^{0} 6$ - Deslocamento do valor de reserva do investidor

A redução do VR detido pelo investidor ampliou a zona de possível acordo $\left(35 \leq \mathrm{P}_{2} \leq 85\right)$. Com isso, tornou-se possível a ocorrência de $\mathrm{P}_{2}<\mathrm{P}_{1}$. Mais crítico do que isso, o investidor poderia até receber pelo lote de plástico um preço inferior ao seu valor de reserva original $\left(\mathrm{P}_{2}\right.$ $<\mathrm{S}_{1}$ ). No entanto, mesmo que o comprador tivesse a intencionalidade oportunista e estivesse disposto a empregar a pilhagem, poderia não ter força suficiente para reduzir o preço final na presença de informação completa. Por esse motivo, e para que ele pudesse dispor da ameaça crível da retirada, foi introduzida a assimetria de informação. Assim, garantiram-se condições reais para que o comprador pudesse pressionar a redução de $\mathrm{P}_{2}$ e expropriar a quase-renda, se assim o desejasse.

Dessa forma, é possível proceder a uma leitura da postura do comprador a partir da análise de $\mathrm{P}_{2}$. Para isso, são consideradas duas possibilidades de se entender o que configuraria a pilhagem ou a manifestação do comportamento oportunista empregado pelo comprador: a

33 Assim que os compradores receberam os envelopes e fizeram a leitura das instruções confidenciais, foi informado verbalmente que os pares tinham 15 minutos para concretizar as novas negociações. 
simples redução no preço acordado $\left(\mathrm{P}_{2}<\mathrm{P}_{1}\right)$; ou o estabelecimento de um preço inferior ao VR que o investidor dispunha na primeira etapa $\left(\mathrm{P}_{2}<\mathrm{S}_{1}\right)$.

Podem existir, naturalmente, controvérsias sobre qual dessas situações espelharia de maneira mais apropriada o que pode ser conceituado como um comportamento oportunista. Talvez seja demasiadamente restrito conceber que o comportamento oportunista ocorreu somente quando se constata $P_{2}<S_{1}$. De outra forma, pode ser defendido que a simples redução do preço não implicaria a materialização do comportamento oportunista, mesmo porque algumas variações negativas podem ser entendidas como correções em acordos desfavoráveis ao comprador. Por exemplo, torna-se difícil sustentar que houve pilhagem quando, depois de estabelecerem um $\mathrm{P}_{1}$ igual a $\$ 85$, os negociadores contratam um $\mathrm{P}_{2}$ igual a $\$ 72,50$, justamente o valor que para alguns seria o $P_{1}$ esperado já na primeira negociação por ser $\mathrm{o}$ ponto médio entre $S_{1}$ e $B_{1}$.

\subsection{Formulários para preenchimento}

Ao final de cada rodada de negociação, os pares de negociação receberam formulários para registrarem suas decisões. Além das questões sobre o resultado da negociação, tais formulários também continham perguntas sobre cada participante e sobre o relacionamento prévio entre os integrantes dos pares de negociação.

Para coletar os dados da primeira etapa de negociações, foram utilizados dois formulários: um específico para os pares que chegaram ao acordo ${ }^{34}$ e outro para os que não obtiveram o consenso $^{35}$. A opção por adotar questionários distintos se justificava, em face das perguntas sobre o relacionamento prévio dos participantes: como a reflexão causada pelas perguntas poderia afetar o comportamento do comprador na segunda rodada de negociação, decidiu-se questionar os participantes somente ao final desse processo. Por outro lado, como os participantes que não obtinham o acordo já estariam dispensados da segunda etapa, eles precisavam responder a essas perguntas logo no primeiro questionário.

\footnotetext{
${ }^{34}$ Ver Apêndice 4.

${ }^{35}$ Ver Apêndice 5.
} 
As perguntas sobre o relacionamento prévio foram:

a) Já se conheciam antes? ( ) Sim ( ) Não

b) Já participaram de algum trabalho ou prova no mesmo grupo? ( ) Sim ( ) Não

c) Têm (ou já tiveram) contato em algum outro grupo social (amigos, empresa-júnior, atlética, trabalho, etc)? ( ) Sim ( ) Não

d) Já fizeram juntos alguma outra disciplina na Faculdade? ( ) Não ( ) Sim, menos de cinco disciplinas ( ) Sim, cinco ou mais disciplinas

As perguntas sobre os participantes, envolvendo idade, sexo, ano de ingresso na faculdade e profissão, foram realizadas ao final da primeira etapa, independentemente do resultado das negociações. Esses formulários ainda continham as perguntas específicas sobre o acordo, da seguinte maneira:

a) Formulário para a primeira rodada com acordo: preço negociado; proponente inicial e valor da proposta inicial;

b) Formulário para a primeira rodada sem acordo: valores do impasse $\mathrm{e}^{36}$; proponente inicial e valor da proposta inicial.

Ao final da segunda rodada, havia um único formulário para preenchimento pelos participantes $^{37}$. Além das já comentadas questões relativas ao conhecimento prévio entre os integrantes do mesmo par, os participantes precisavam responder se houve acordo; e informar o preço acordado (no caso de terem chegado a um consenso) ou os valores do impasse.

Esse formulário ainda apresentou duas questões específicas para o investidor, tratando da confidencialidade de $\mathrm{B}_{2}$. O investidor deveria informar se o comprador havia revelado o valor da proposta submetida pelo produtor estrangeiro e, em caso de resposta afirmativa, qual fora o valor revelado. Nesse caso, a eventual revelação de algum valor falso, abaixo de $\mathrm{B}_{2}$, configuraria flagrante de comportamento oportunista, independentemente do desfecho da negociação.

\footnotetext{
${ }^{36}$ Refere-se ao maior preço ofertado pelo comprador, e ao menor preço ofertado pelo investidor.

${ }^{37}$ Ver Apêndice 6.
} 


\section{APRESENTAÇÃO DOS RESULTADOS}

Neste capítulo, são apresentados os resultados das negociações. Os acordos e impasses nas duas etapas de negociação, assim como os preços pactuados nos acordos, são abordados na seção 7.1, na qual também são analisadas as situações que podem ser enquadradas como comportamento oportunista. Na seção 7.2, examinam-se algumas associações entre as manifestações desse comportamento e as posturas e características dos compradores e investidores.

\subsection{Manifestações do comportamento oportunista}

Já foi comentado que o valor de reserva do comprador (B) em excesso ao valor de reserva do vendedor (S) configura a existência de uma zona de acordo, na qual se espera que qualquer preço acordado entre esses agentes esteja inserido. No experimento aplicado no curso deste estudo, sempre houve uma zona de acordo, de sorte que era esperado que os preços pactuados para o lote de plástico estivessem compreendidos nessa região. Caso os participantes da negociação estabelecessem preços inferiores a $S$ ou superiores a $B$, essa ocorrência demonstraria não entendimento das regras da negociação ou desinteresse pelo resultado financeiro no experimento, comprometendo assim o objetivo da pesquisa. ${ }^{38}$ A esse respeito, entre os 88 pares que estabeleceram negociações, houve somente cinco casos em que os acordos violaram os valores de reserva na primeira ou segunda rodada. Em razão do reduzido número de ocorrências, e da dificuldade de análise desses dados, esses pares foram excluídos da amostra.

Uma outra situação que poderia prejudicar a pesquisa seria o não estabelecimento do acordo na primeira etapa de negociação, quando o investidor tinha que decidir se promoveria ou não o investimento em ativos específicos. Ora, a pesquisa pretendia observar o comportamento na renegociação, mas esta somente ocorreria para os pares que chegassem a um consenso na

\footnotetext{
${ }^{38}$ Para situações em que o preço acordado na primeira rodada ficou acima de $\$ 85$, pode ser aventada a possibilidade de o investidor ter cobrado um prêmio para compensar o investimento no ativo específico. Apesar dessa hipótese ser factível, deve ser considerado que, pelo menos no curto prazo, o comprador não maximizou seu retorno, já que adquiriu o produto por um valor superior ao cobrado pelo produtor estrangeiro.
} 
etapa precedente. Se o comprador falhasse em induzir o investidor a promover os investimentos para produzir o lote de plástico, o problema de pesquisa não poderia ser testado. ${ }^{39}$ Sobre essa situação, considerando os 83 resultados válidos, houve apenas cinco casos em que o investidor optou por não construir a fábrica de plástico. Conforme já relatado anteriormente, acredita-se que o próprio desejo de participar da segunda etapa do experimento tenha favorecido o estabelecimento do acordo.

Já na segunda etapa de negociação, com a redução do VR detido pelo investidor e o surgimento da informação assimétrica, seria razoável atribuir maior dificuldade à concretização do acordo, principalmente se o comprador optasse por tirar grande proveito do investidor. No entanto, de forma diversa da situação precedente, o fato de os participantes não chegarem a um acordo nesse estágio não comprometeria a pesquisa proposta, já que seria possível observar os valores do impasse e analisar o comportamento do comprador, por meio do último preço por ele proposto. O próprio impasse já é um prenúncio de que o comprador tenha agido oportunisticamente, mas é necessário analisar as propostas submetidas pelos integrantes do par em questão.

Cabe salientar que somente três pares não obtiveram um consenso na segunda etapa. Em dois deles, flagrantemente os compradores procuraram forçar a negociação. A título de exemplo, num dos pares o impasse ficou em $\$ 50$ e \$ 70. O comprador agressivamente se empenhou em ampliar o seu ganho, já que os participantes haviam estabelecido o preço na etapa anterior em \$ 76. Apesar de o investidor já ter cedido parte de suas quase-rendas, sugerindo o estabelecimento do preço em $\$ 70$, o comprador não cedeu, e adquiriu o lote de plástico junto ao produtor estrangeiro por $\$ 85$. É provável que o tempo tenha sido uma variável crítica, e que os negociadores avançariam nas concessões até o estabelecimento do acordo. De toda forma, é possível afirmar que o comprador tentou empregar um comportamento oportunista; por outro lado, é possível supor que o investidor repudiou essa tentativa: preferiu punir a contraparte, ainda que, por conta disso, tenha arcado com um prejuízo financeiro ao descontinuar a transação.

39 Mesmo que poucos pares chegassem ao acordo na primeira etapa, comprometendo a observação das renegociações, acredita-se que o experimento seria de grande utilidade, já que proporcionaria hipóteses intrigantes sobre o reconhecimento ex-ante dos riscos associados ao investimento em ativos específicos. 
Nos 75 pares restantes, investidor e comprador desempenharam negociações com sucesso nas duas rodadas, já que conseguiram maximizar o ganho conjunto em virtude de fecharem o acordo. Esse sucesso na construção do consenso, porém, pode significar um resultado pessoal até mesmo insatisfatório para algum dos lados, já que a partilha do excedente nem sempre se deu em termos eqüitativos. Além disso, na segunda etapa de negociação, constata-se a presença de comportamento oportunista em alguns casos.

Na primeira rodada, considerando apenas os 75 casos que obtiveram o duplo acordo, o preço $\left(\mathrm{P}_{1}\right)$ médio foi de $\$ 72,13$. Percebe-se que a necessidade de investimentos em ativos específicos por parte do investidor não fez com que o preço final fosse superior à média entre os valores de reserva $\left(S_{1}=\$ 60\right.$ e $\left.B_{1}=\$ 85\right)$. Ao contrário, parece que o ponto médio entre os valores de reserva foi decisivo. Em 15 pares (20\% do total), o preço pactuado foi exatamente $\$ 72,50$. Apesar disso, não é possível afirmar que exista uma tendência ao valor central da zona de possível acordo, já que outras informações, tais como o lucro apurado pelo comprador, poderiam, se reveladas, atuar como valores de referência para os negociadores. Já na segunda rodada, com a introdução da confidencialidade do VR do comprador $\left(\mathrm{B}_{2}=\$ 85\right) \mathrm{e}$ com a alteração do VR do investidor (de $S_{1}=\$ 60$ para $\left.S_{2}=\$ 35\right)$, o preço acordado $\left(\mathrm{P}_{2}\right)$ médio foi de $\$ 66,85$. Além da redução do preço médio em $\$ 5,28$, outro dado relevante foi o aumento da dispersão dos preços: no primeiro estágio, o desvio-padrão foi de 4,68; no segundo, de 9,53 .

Conforme discussão promovida no capítulo anterior, além dessa evolução negativa dos preços acordados na primeira e segunda rodada $\left(\mathrm{P}_{2}<\mathrm{P}_{1}\right)$, a ocorrência de $\mathrm{P}_{2}$ inferior a $\mathrm{S}_{1}$ também pode ser admitida como critério para considerar que houve emprego do comportamento oportunista. Nessa circunstância, o preço negociado é insuficiente para cobrir o VR que o investidor detinha antes de promover os investimentos em ativos específicos $\left(\mathrm{P}_{2}<\mathrm{S}_{1}\right)$.

O gráfico 1 permite analisar se ocorreu o comportamento oportunista de acordo com o critério da redução $\left(\mathrm{P}_{2}<\mathrm{P}_{1}\right)$. Nele estão plotados os pontos que representam o preço negociado na primeira rodada de negociação $\left(\mathrm{P}_{1}\right)$ e a evolução do preço entre a primeira e a segunda rodada $\left(\mathrm{P}_{2}-\mathrm{P}_{1}\right){ }^{40}$ Conforme evidenciado nesse gráfico, e adotando a concepção de que existiu

${ }^{40}$ Alguns pontos plotados nesse gráfico foram representados com uma área maior, indicando sobreposição de ocorrências. Em outras palavras, as áreas diferenciadas revelam que: o ponto $(72,5 ; 0)$ corresponde a cinco pares de negociação que pactuaram os mesmos preços nas duas rodadas; cada um dos pontos $(70 ; 0)$ e $(75 ; 0)$ 
comportamento oportunista quando $\mathrm{P}_{2}$ foi inferior a $\mathrm{P}_{1}$, conclui-se que em $62,7 \%$ dos casos (47 pares) os agentes teriam se comportado oportunisticamente. Nos demais casos, o preço se manteve $\left(\mathrm{P}_{2}=\mathrm{P}_{1}\right)$ ou mesmo se elevou $\left(\mathrm{P}_{2}>\mathrm{P}_{1}\right)$. $\mathrm{O}$ gráfico também demonstra que essas reduções ocorreram independentemente de $\mathrm{P}_{1}{ }^{41}$ Nessa configuração do comportamento oportunista, embora o investidor venda o lote de plástico por um valor menor do que o pactuado na primeira negociação, a remuneração obtida pode ainda ser superior ao VR que ele detinha na primeira etapa. Portanto, a materialização dessa concepção de comportamento oportunista não necessariamente torna o acordo insatisfatório ao investidor quando esse agente compara sua recompensa efetiva com a proporcionada pelo mercado financeiro.

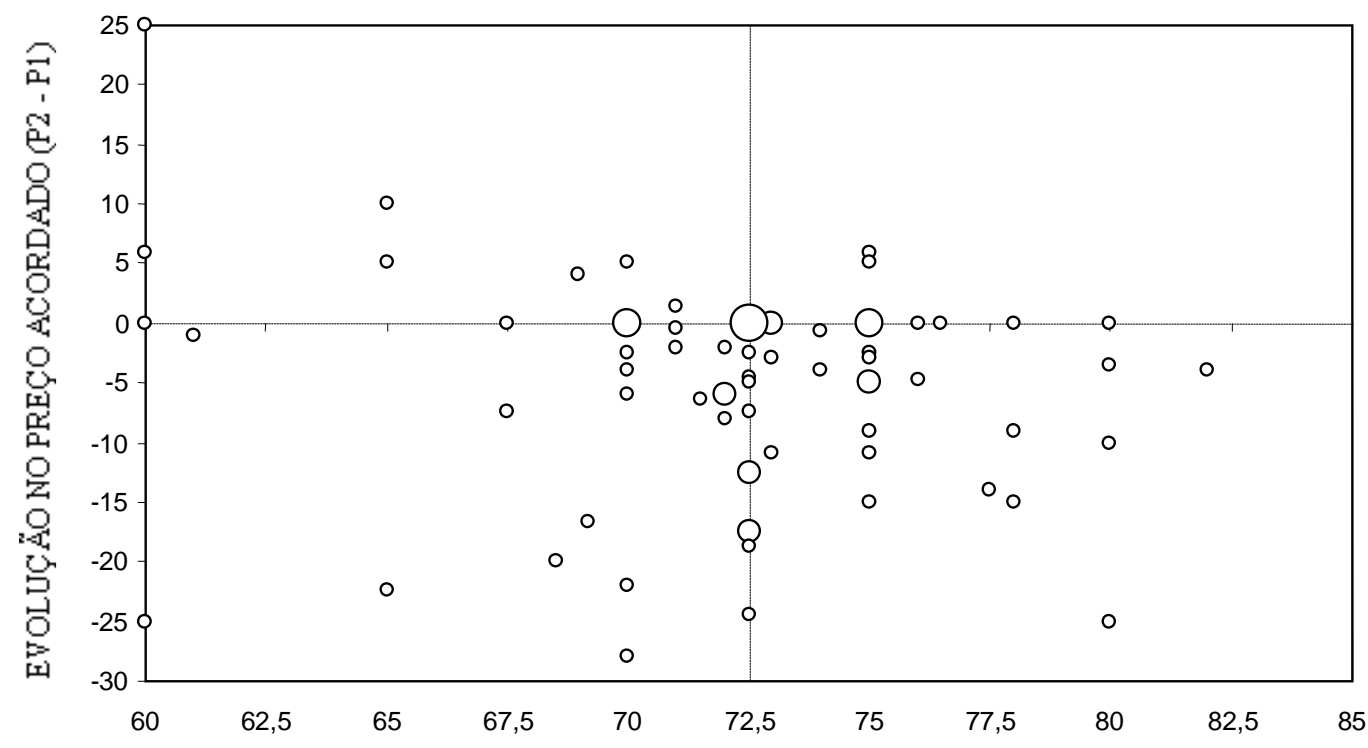

PREÇO ACORDADO NA PRIMEIRA RODADA $\left(\mathrm{P}_{1}\right)$

Gráfico no 1 - Evolução dos preços negociados

A propósito, o outro critério para considerar se houve comportamento oportunista trata justamente desse tema. Nessa outra configuração, o comportamento oportunista somente seria evidenciado se ocorresse $\mathrm{P}_{2}<\$ 60$, pois para qualquer outro resultado, o investidor ainda estaria auferindo um resultado superior àquele detido antes de celebrar o primeiro acordo. A visualização dessas ocorrências pode ser promovida no gráfico 2, no qual estão plotados os

corresponde a três pares; e cada um dos pontos $(72 ;-6),(72,5 ;-12,5),(72,5 ;-17,5),(73 ; 0)$ e $(75 ;-5)$ corresponde a dois pares.

${ }^{41}$ A partir de uma série de variáveis (Apêndice 7), foram construídas regressões lineares simples e múltiplas tendo por objetivo identificar associações com a variável dependente evolução do preço $\left(\mathrm{P}_{2}-\mathrm{P}_{1}\right)$. Não foram encontradas associações significativas entre $\mathrm{P}_{1}$ e a evolução do preço $(\mathrm{p}<0,5)$. Ver Apêndices 8 e 11. 
pontos que representam os preços acordados na primeira $\left(\mathrm{P}_{1}\right)$ e na segunda etapa de negociação $\left(\mathrm{P}_{2}\right){ }^{42}$

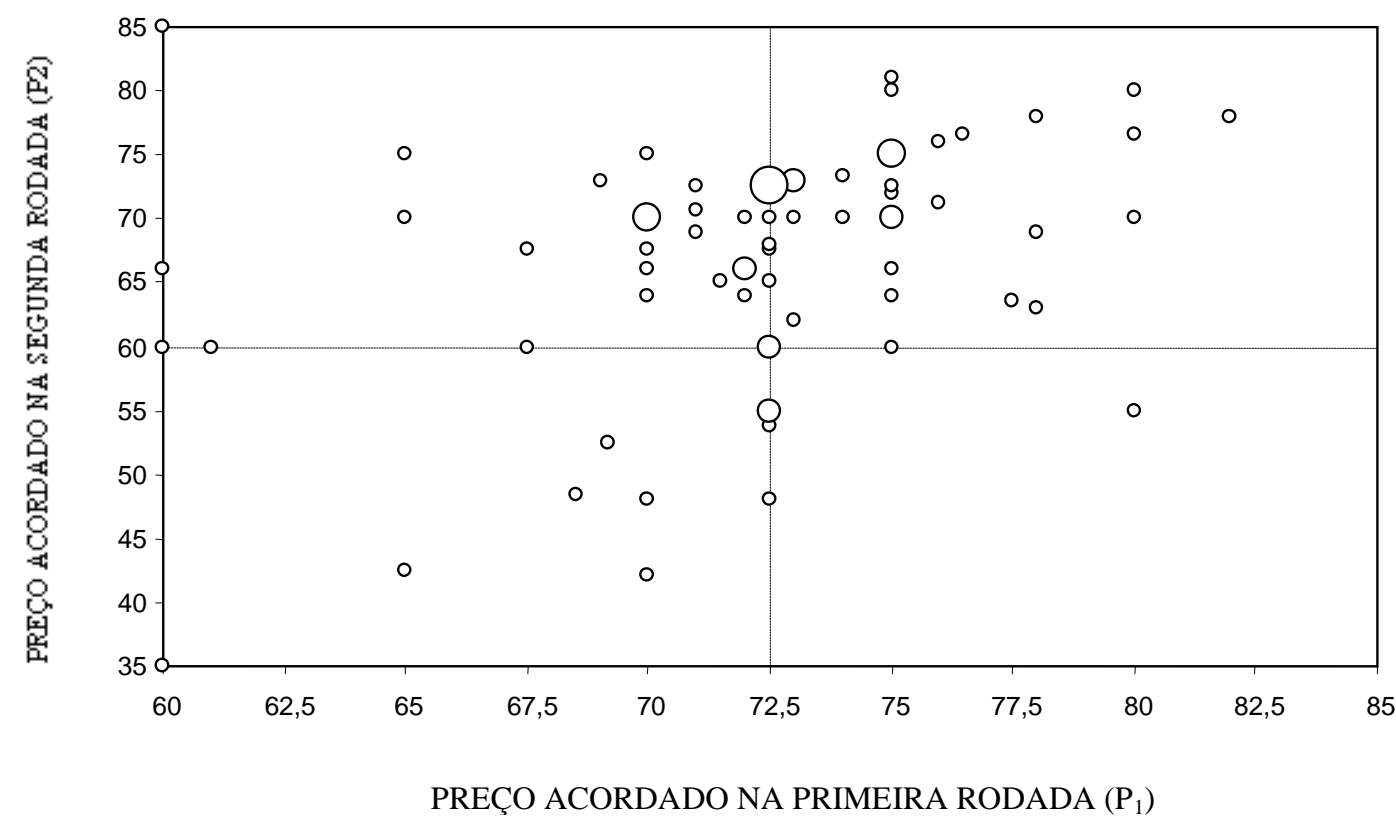

Gráfico no 2 - Comparação entre $P_{1}$ e $P_{2}$

Ao considerar esse critério, constata-se que o comportamento oportunista somente teria ocorrido em 14,7\% dos pares (11 ocorrências). É importante notar que apenas um desses casos foi precedido de $\mathrm{P}_{1}>\$ 72,50$. Logo, o acordo favorável na primeira etapa foi, na grande maioria dos casos, suficiente para evitar $\mathrm{P}_{2}<\$ 60$. Porém, apesar de a negociação favorável no primeiro estágio ter minimizado a ocorrência de $\mathrm{P}_{2}<\$ 60$ na etapa posterior, não é possível afirmar que esse resultado positivo continuaria sendo presenciado se houvesse mais rodadas de negociação. Talvez o preço permanecesse caindo ao longo das renegociações, de forma que o acordo favorável na primeira situação não implicasse vantagem no longo prazo.

Além dessas concepções relacionadas diretamente com o preço praticado, é relevante observar que a própria postura do comprador em relação à confidencialidade de $\mathrm{B}_{2}$ revela informações sobre o comportamento oportunista. Considerando os 78 pares que participaram da segunda rodada, a maioria (60 compradores) preferiu manter esse valor oculto, talvez

${ }^{42}$ A exemplo do gráfico 1, a área expandida de alguns pontos reflete a sobreposição de ocorrências. O ponto $(72,5 ; 72,5)$ corresponde a cinco pares de negociação que pactuaram os mesmos preços nas duas rodadas; cada 
beneficiando-se com o fato de o investidor desconhecer $B_{2}$. Entre aqueles que se pronunciaram quanto ao VR, apenas dez compradores revelaram corretamente o preço oferecido pelo produtor estrangeiro, e houve oito casos em que o comprador decididamente resolveu trapacear, informando preços falsos, menores do que \$ 85. Para este último caso, é relevante lembrar que Williamson inclui a mentira e a trapaça entre as formas mais flagrantes do comportamento oportunista.

Neste momento, é preciso salientar que o experimento comportou particularidades que poderiam incentivar ou desencorajar a pilhagem. Por exemplo, se na vida real, principalmente entre aqueles que desenvolvem atividades nos mesmos setores da economia, os agentes têm incertezas quanto a transações futuras; os participantes do experimento sabiam, ao negociar o preço do lote na segunda rodada, que não haveria uma etapa posterior. Por outro lado, mesmo com a ausência de negociações subseqüentes, o participante que desempenhava o papel de comprador poderia considerar eventuais reflexos nas interações da vida real.

Além disso, outro detalhe de relevo é que o comprador não sabia se $\mathrm{B}_{2}$ seria revelado ao investidor depois de concluído o experimento. Nesse caso, o participante no papel de comprador poderia vir a sofrer algum desgaste na sua reputação se a contraparte - ou outros participantes - soubesse a posteriori que ele mentiu no experimento. Portanto, o comprador possivelmente estaria numa situação mais confortável para enganar a contraparte, se lhe fosse assegurado que, mesmo depois de encerradas as negociações, não haveria revelação do verdadeiro $B_{2}$.

\subsection{Associações com o comportamento oportunista}

Considerando as já comentadas concepções do que se entende por comportamento oportunista, a pesquisa realizada definitivamente revelou casos em que o comprador empregou a pilhagem do investidor. Em face disso, procura-se nesta seção verificar se existem associações entre a ocorrência desse comportamento e características dos participantes. Na seção 7.2.1, são examinadas algumas situações que poderiam mitigar o

um dos pontos $(70 ; 70)$ e $(75 ; 75)$ corresponde a três pares; e cada um dos pontos $(72 ; 66),(72,5 ; 60),(72,55)$, $(73,73)$ e $(75,70)$ corresponde a dois pares. 
comportamento oportunista. As eventuais associações entre pilhagem e outras variáveis são analisadas na seção 7.2.2.

\subsubsection{Possíveis restrições ao comportamento oportunista}

Baseando-se na discussão sobre restrições ao comportamento oportunista, promovida na seção 4.5, supõe-se que alguns fatores poderiam, em tese, contribuir para inibir a ocorrência da pilhagem na segunda rodada de negociação. Entre esses fatores, é importante considerar o relacionamento prévio dos participantes e a postura empregada na primeira rodada de negociação. Para investigar a eventual influência desses fatores, foram selecionadas as seguintes variáveis:

a) Conhecimento prévio - o fato de os participantes já se conhecerem antes da realização do experimento poderia reduzir a presença do comportamento oportunista, em razão dos prováveis laços de amizade e coleguismo. Além disso, é de se supor que os conhecidos tenham uma probabilidade maior de se interagir no futuro, razão pela qual a expectativa de perdas futuras poderia superar a recompensa presente com o comportamento oportunista. Outro motivo que ainda possibilitaria uma eventual redução na postura oportunista é que, provavelmente, esses alunos teriam mais amigos em comum, de forma que o emprego da pilhagem poderia causar uma imagem negativa entre os seus pares;

b) Disciplinas anteriores - independentemente de os participantes se conhecerem, o fato de terem cursado juntos alguma disciplina pode apresentar efeitos semelhantes ao esperado na ocorrência de conhecimento prévio dos participantes;

c) Proposta justa ou generosa do investidor - quando o investidor é o primeiro falar sobre preços e propõe a entrega do lote de plástico por \$ 72,50 ou menos, não somente ele se compromete a promover o investimento em ativos específicos, como também formula um lance inicial que pode ser entendido como uma proposta justa ou generosa. De acordo com a norma da reciprocidade, o comprador ficaria motivado a recompensar esse gesto favorável do investidor, o que poderia levá-lo a não empregar a pilhagem na etapa subseqüente;

d) Proposta justa ou generosa do comprador - ao propor a aquisição do lote de plástico por \$ 72,50 ou mais, o comprador demonstra-se pouco competitivo. Com esse gesto, parece não estar profundamente interessado em ganhar mais que o outro lado, talvez por atribuir 
importância a outros aspectos da negociação. Se isso for verdade, não haveria, em princípio, motivações para agir oportunisticamente quando ocorre a ampliação no seu poder relativo de barganha.

Para que tais situações possam ser analisadas, foi descrito, na primeira linha da tabela 2, um panorama geral do comportamento adotado pelos 75 pares que obtiveram o acordo nas duas etapas. Em consonância com a discussão apresentada na seção 7.1, essa tabela apresenta a quantidade e o percentual de pares em que houve comportamento oportunista de acordo com as seguintes concepções:

a) Participantes pactuaram na renegociação preço inferior ao estabelecido na etapa inicial $\left(\mathrm{P}_{2}\right.$ $\left.<\mathrm{P}_{1}\right)$;

b) Participantes pactuaram na renegociação preço inferior ao valor de reserva detido pelo investidor na etapa inicial $\left(\mathrm{P}_{2}<\$ 60\right)$;

c) Comprador divulgou ao investidor valor incorreto de $\mathrm{B}_{2}$ (valor revelado de $\mathrm{B}_{2} \neq \$ 85$ ).

Além disso, a última coluna dessa tabela apresenta a evolução média dos preços entre os dois estágios $\left(\mathrm{P}_{2}-\mathrm{P}_{1}\right)$, o que também pode ser visto como um índice do comportamento oportunista.

Tabela $n^{\circ} 2$ - Situações que poderiam reduzir o comportamento oportunista

\begin{tabular}{|c|c|c|c|c|c|}
\hline Ocorrência & $\begin{array}{l}\text { Quantidade } \mathrm{d} t \\
\text { ocorrências }\end{array}$ & $\mathrm{P}_{2}<\mathrm{P}_{1}$ & $\mathrm{P}_{2}<60$ & $\begin{array}{c}\text { Valor } \\
\text { revelado de } \\
\mathrm{B}_{2} \neq 85\end{array}$ & $\begin{array}{c}\text { Evolução } \\
\text { média dos } \\
\text { preços } \\
\left(\mathrm{P}_{2}-\mathrm{P}_{1}\right)\end{array}$ \\
\hline Total de pares & 75 & $\begin{array}{c}47 \\
62,7 \%\end{array}$ & $\begin{array}{c}11 \\
14,7 \%\end{array}$ & $\begin{array}{c}8 \\
10,7 \%\end{array}$ & $-5,28$ \\
\hline Conhecimento prévio & 14 & $\begin{array}{c}11 \\
78,6 \%\end{array}$ & $\begin{array}{c}6 \\
42,9 \%\end{array}$ & $\begin{array}{c}1 \\
7,1 \%\end{array}$ & $-10,70$ \\
\hline Disciplinas anteriores & 21 & $\begin{array}{c}12 \\
57,1 \%\end{array}$ & $\begin{array}{c}4 \\
19,0 \%\end{array}$ & $\begin{array}{c}1 \\
4,8 \%\end{array}$ & $-6,27$ \\
\hline $\begin{array}{c}\text { Proposta justa ou generosa do } \\
\text { investidor }\end{array}$ & 6 & $\begin{array}{c}2 \\
33,3 \%\end{array}$ & $\begin{array}{c}1 \\
16,7 \%\end{array}$ & $\begin{array}{c}1 \\
16,7 \%\end{array}$ & $-4,17$ \\
\hline $\begin{array}{l}\text { Proposta justa ou generosa do } \\
\text { comprador }\end{array}$ & 7 & $\begin{array}{c}3 \\
42,9 \%\end{array}$ & $\begin{array}{c}0 \\
0 \%\end{array}$ & $\begin{array}{c}0 \\
0 \%\end{array}$ & $-3,50$ \\
\hline
\end{tabular}


Nas demais linhas da tabela 2, foram abordadas as já comentadas situações que poderiam mitigar a ocorrência do comportamento oportunista. Desses dados, merecem destaque os resultados dos pares cujos componentes informaram já se conhecerem. Isso porque, diferentemente do que se esperava, a pilhagem nesse caso foi mais freqüente. Em termos relativos, quando pactuado por conhecidos, $\mathrm{P}_{2}$ foi mais vezes inferior a $\mathrm{P}_{1}$, bem como foi com maior frequiência menor do que $\$ 60$. Além disso, os preços apresentaram uma redução média de $\$ 10,70$ nesse grupo, contra um declínio médio de $\$ 5,28$ na totalidade dos 75 pares.

Se houve mais casos de comportamento oportunista na presença de conhecimento prévio, o estudo não permitiu vislumbrar significativa redução desse comportamento na presença das outras variáveis estudadas. Embora possa ser constatada alguma redução nas situações em que um dos lados se mostrou mais justo ou generoso no primeiro estágio, essa postura inicial menos competitiva ocorreu poucas vezes, de sorte que não é possível afirmar que exista consistência nesses resultados.

\subsubsection{Associações do comportamento oportunista com outras variáveis}

A pesquisa promovida também possibilitou examinar a ocorrência do comportamento oportunista na presença de outras características dos participantes. Nessa análise, não foram constatadas associações entre a pilhagem e as variáveis relacionadas à idade dos participantes, ao ano de ingresso na faculdade e ao ato de exercer alguma profissão. Da mesma maneira, o responsável - comprador ou investidor - pela proposta inicial na primeira rodada não causou qualquer efeito significativo. ${ }^{43}$

Além do conhecimento prévio, discutido na seção precedente, a variável cujos indícios de associações mereceram atenção foi o sexo do comprador. Para analisar o caso, a ilustração 7 apresenta as evidências do comportamento oportunista, segmentando os pares de acordo com os sexos do comprador e do investidor. ${ }^{44} \mathrm{O}$ exame dessas informações revela que o

\footnotetext{
43 Nas regressões lineares simples e múltiplas construídas com objetivo de explicar a variável dependente evolução do preço $\left(\mathrm{P}_{1}-\mathrm{P}_{2}\right)$, a única variável cujo coeficiente apresentou associação significativa $(\mathrm{p}<0,05)$ foi o conhecimento prévio (Apêndice 9). Em que pese o reduzido valor do $\mathrm{R}^{2}$ ajustado, a regressão pode ser utilizada para constatar que o conhecimento prévio entre os integrantes está associado a uma maior redução dos preços.

${ }^{44}$ Enquanto as áreas representadas nessa ilustração pela cor amarela somente são consideradas como evidências da pilhagem pelo critério da redução $\left(\mathrm{P}_{2}<\mathrm{P}_{1}\right)$, as áreas em vermelho enquadram-se como manifestações do comportamento oportunista em qualquer critério considerado, já que há redução de preços $\left(\mathrm{P}_{2}<\mathrm{P}_{1}\right)$ e o preço é
} 
comportamento oportunista, na forma de $\mathrm{P}_{2}<\mathrm{P}_{1}$ ou de $\mathrm{P}_{2}<\$ 60$, foi sensivelmente maior nos pares em que o comprador era do sexo masculino, independentemente do sexo do investidor. Cabe destacar que nos pares com compradores do sexo masculino, os preços apresentaram uma redução média de $\$ 6,34$, ao passo que nos pares cujos compradores eram do sexo feminino houve um declínio médio de \$3,16. Quanto à outra variável sob análise na ilustração 7, não se constata associação com a ocorrência da pilhagem.

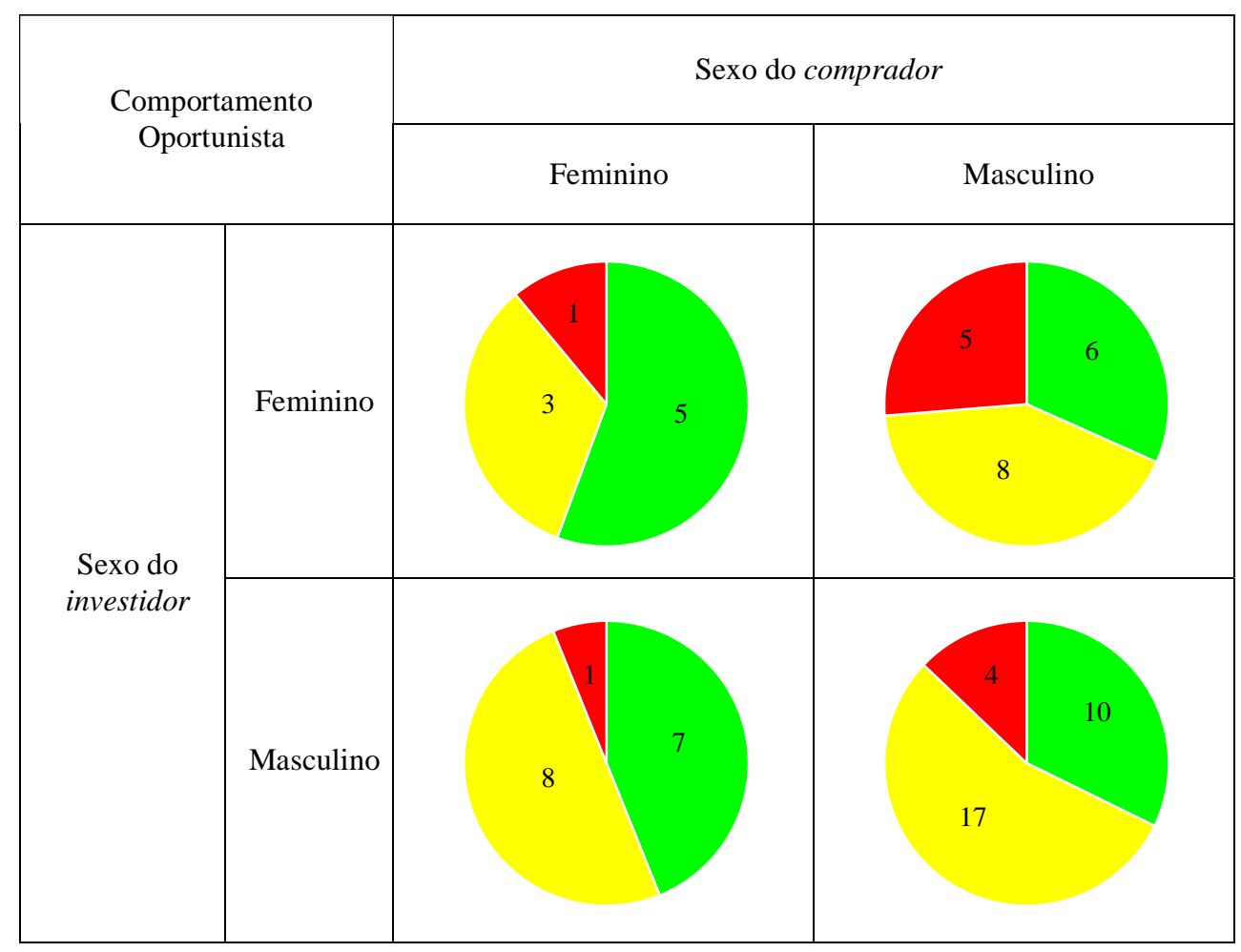

$\square$ Ausência de comportamento oportunista

$\square$ Comportamento oportunista ou não: $60<\mathrm{P}_{2}<\mathrm{P}_{1}$

Comportamento oportunista: $\mathrm{P}_{2}<60$

Ilustração $n^{\circ} 7$ - Evidências do comportamento oportunista

Tendo em conta que o comportamento oportunista apresentou indícios de associações com o conhecimento prévio e com o sexo do comprador, a ilustração 8 visa isolar cada uma dessas associações. ${ }^{45}$ Com isso, analisando somente os pares cujos integrantes não se conheciam, nota-se que o sexo do comprador parece ter, no máximo, importância reduzida na

insuficiente para cobrir o valor de reserva inicial do investidor $\left(\mathrm{P}_{2}<\mathrm{S}_{1}\right)$. Os números inseridos em cada área representam a quantidade de ocorrências.

45 Aplicam-se, para essa ilustração, as mesmas considerações dispostas na nota de rodapé 44. 
determinação da pilhagem. A menor relevância dessa variável também pode ser constatada quando se analisa a evolução dos preços $\left(\mathrm{P}_{2}-\mathrm{P}_{1}\right)$ : entre os não conhecidos, a redução em pares com compradores do sexo masculino foi de $\$ 4,58$, contra um declínio médio de $\$ 3,07$ em pares cujos compradores eram do sexo feminino.

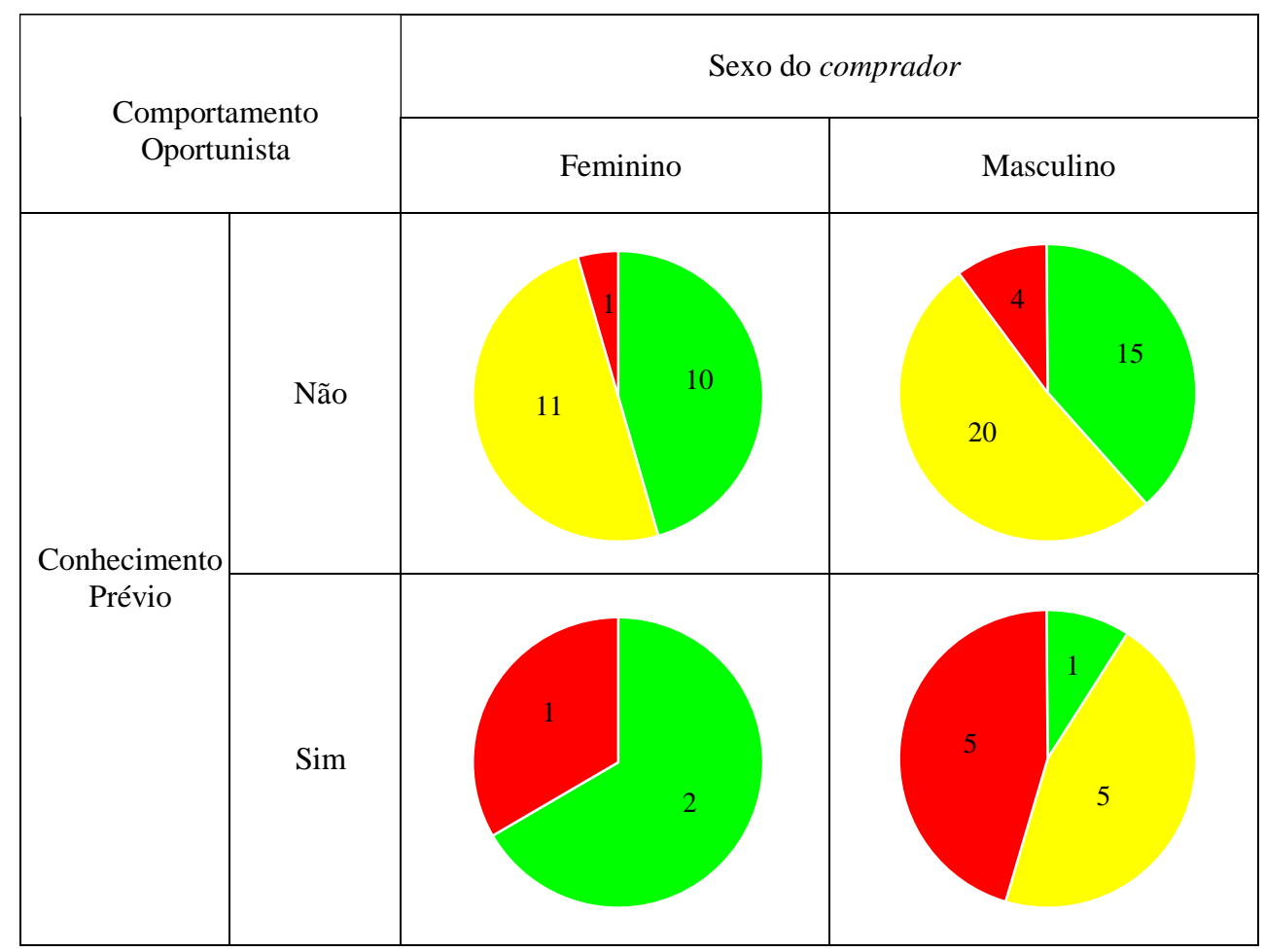

$\square$ Ausência de comportamento oportunista

$\square$ Comportamento oportunista ou não: $60<\mathrm{P}_{2}<\mathrm{P}_{1}$

$\square$ Comportamento oportunista: $\mathrm{P}_{2}<60$

\section{Ilustração no 8 - Evidências do comportamento oportunista}

A análise de eventuais associações entre pilhagem e sexo do comprador no grupo dos conhecidos resta prejudicada em razão do pequeno número de pares com integrantes conhecidos e com comprador do sexo feminino. Em razão disso, e como foram reduzidas as diferenças na quantidade e intensidade das pilhagens no grupo dos que não se conheciam, pode-se dizer que não existem indícios significativos de associação do comportamento oportunista com o sexo do comprador. ${ }^{46}$

${ }^{46}$ Conforme já relatado na nota de rodapé 43, não foram constatadas associações significativas entre sexo do comprador e evolução do preço acordado $\left(\mathrm{P}_{2}-\mathrm{P}_{1}\right)$. Ver Apêndices 10 e 11. 
Ora, se houve em termos absolutos mais pilhagens quando o comprador era do sexo masculino, mas esse fenômeno é fortemente reduzido ao se considerar o conhecimento prévio dos participantes, parece que esta última variável realmente apresenta associações com o comportamento oportunista. Essa afirmação é corroborada pelos dados da ilustração 8, já que os compradores do sexo masculino empregaram a pilhagem com maior freqüência quando conheciam o investidor. Ainda considerando os compradores do sexo masculino, nota-se que a influência do conhecimento prévio também pode ser constatada pela evolução dos preços: a redução média foi de $\$ 12,57$ entre conhecidos contra $\$ 4,58$ em pares cujos integrantes não se conheciam. Não é possível afirmar que esse padrão se estendeu para compradores do sexo feminino, em razão do já comentado reduzido número de pares com comprador do sexo feminino e com integrantes conhecidos.

As informações presentes na ilustração 8 ainda permitem constatar que 22\% (11 em 50) dos compradores de sexo masculino negociaram com um investidor conhecido. Por outro lado, entre os compradores do sexo feminino, apenas $12 \%$ (3 em 25) negociaram nessas condições. Como de maneira geral, os compradores foram mais agressivos na pilhagem dos conhecidos, essa desproporção parece explicar, pelo menos em parte, o porquê de os compradores homens terem empregado o comportamento oportunista com maior freqüência e intensidade. 


\section{CONCLUSÃO}

De acordo com Raiffa, as negociações podem ser representadas pela zona de acordo, sempre que o valor de reserva (VR) do comprador é superior ao VR do vendedor. Este trabalho teve por objetivo utilizar essa formalização para analisar as renegociações. Para tanto, foram incorporados alguns elementos da Economia dos Custos de Transação (ECT), representados pela racionalidade limitada, especificidade de ativos e oportunismo. Em razão da racionalidade limitada, os acordos e contratos são incompletos, já que a previsão de todas as contingências é impossível ou, na melhor das hipóteses, demasiado dispendiosa. Com isso, freqüentemente as partes necessitam promover revisões contratuais, o que demanda $o$ estabelecimento de negociações após a realização do acordo. Ocorre que, entre a negociação e a renegociação, se uma das partes investir em ativos específicos à transação, o seu VR se torna menos favorável, reduzindo o seu poder relativo de negociação. Nessas condições, no momento em que as partes envolvidas estabelecem a renegociação, o agente que promoveu os investimentos específicos pode ficar à mercê do comportamento oportunista da contraparte.

Apesar de os teóricos da ECT adotarem o oportunismo como pressuposto comportamental, afirmam que nem todos os indivíduos agem oportunisticamente o tempo todo. As sanções contratuais, a frequiência das transações e a necessidade de desenvolver reputação apresentamse como restrições a esse comportamento. Além disso, alguns estudiosos entendem que os agentes podem não empregar o comportamento oportunista nas renegociações, já que muitas pessoas procurariam recompensar os indivíduos que no passado lhe fizeram alguma ação favorável. Dessa forma, este trabalho também teve por objetivo descobrir se os agentes empregam ou não um comportamento oportunista nas renegociações em que o valor de reserva da contraparte se deteriorou por conta dos investimentos específicos.

As pesquisas envolvendo negociações são de difícil realização, pois as pessoas costumam omitirem os seus limites, mesmo depois de encerradas as negociações. Por esse motivo, optou-se pela realização de uma pesquisa experimental, já que a simulação das negociações garante o conhecimento dos valores de reserva das partes. Os participantes do experimento foram alunos do curso de Administração oferecido pela Universidade de São Paulo, os quais foram aleatoriamente agrupados em pares, nos papéis de investidor e comprador. 
O experimento simulou duas rodadas de negociação, nas quais os participantes poderiam ou não concluir um acordo quanto ao preço de fornecimento de um determinado produto. $\mathrm{Na}$ primeira etapa, o investidor precisava realizar investimentos específicos para dispor do produto em questão, e assim vendê-lo ao comprador. Caso não chegassem a um consenso, o investimento não era realizado e cada um dos participantes auferia o resultado proporcionado pelo seu VR. A zona de acordo era conhecida por ambos os lados. Já na renegociação, o VR detido pelo comprador não foi revelado ao investidor. Somente o comprador recebeu um envelope confidencial informando que seu VR permanecia inalterado, ou seja, no mesmo patamar que na etapa anterior. Além disso, nessa segunda etapa, o investidor sofreu deterioração no seu VR, em razão dos investimentos específicos promovidos na etapa precedente.

A pesquisa realizada não visou identificar a intenção do agente que tem o seu poder relativo de negociação ampliado, mas teve por propósito observar o seu comportamento. Mais especificamente, o experimento permitiu a observação do emprego da pilhagem nas renegociações em que a contraparte tem o seu VR deteriorado. Para isso, denominou-se de pilhagem: a redução do preço de um estágio para o outro $\left(\mathrm{P}_{2}<\mathrm{P}_{1}\right)$; ou, numa concepção mais conservadora, o estabelecimento do preço na renegociação em patamar inferior ao valor de reserva que o investidor dispunha no início do experimento $\left(\mathrm{P}_{2}<\mathrm{S}_{1}\right)$.

Da análise dos resultados, pôde-se constatar que em 62,7\% dos pares o comprador expropriou alguma parcela das quase-rendas antes auferida pelo investidor, ao pactuar no segundo estágio um preço inferior ao acordado na negociação inicial. Em 14,7\% dos pares, o comprador chegou mesmo a expropriar uma parcela maior do que as quase-rendas decorrentes da especificidade inicial. Nesse caso, o investidor foi remunerado com um preço insuficiente até para cobrir o VR que ele dispunha antes de iniciar a primeira rodada de negociações. $\mathrm{O}$ experimento ainda demonstrou que oito compradores revelaram um VR incorreto para o investidor, dessa maneira empregando uma forma flagrante de comportamento oportunista.

Foram examinadas as associações porventura existentes entre a pilhagem e as características dos participantes, bem como entre a pilhagem e as posturas adotadas na primeira rodada de negociação. Descobriu-se que o conhecimento prévio apresentou indícios de associações, mas no sentido inverso ao que se supunha: houve mais casos de pilhagem e com maior intensidade 
nos pares em que os compradores já conheciam os investidores. É possível que o emprego da pilhagem com conhecidos tenha sido visto como indicador de esperteza ou malandragem, de tal forma que o comprador percebia o emprego do comportamento oportunista como algo positivo, que seria apreciado pelo grupo. Outra possível explicação para o caso é que o simples fato de os participantes se conhecerem não garante que entre eles tenha se desenvolvido algum laço de amizade ou coleguismo. Deve-se ainda considerar que, por não ter existido preocupação em controlar as variáveis independentes, os pares com integrantes conhecidos representaram apenas 14 casos no universo de 75 pares que obtiveram o acordo nas duas rodadas de negociação.

Apesar de os compradores do sexo masculino terem, em termos absolutos, empregado a pilhagem com maior freqüência, não foi possível concluir que exista algum indício de associação entre compradores homens e comportamento oportunista. Os compradores do sexo masculino, quando comparados em termos relativos com os compradores do sexo feminino, negociaram mais vezes com conhecidos, o que pelo menos em parte pareceu explicar a maior ocorrência do comportamento oportunista. Dessa forma, ao deduzir o efeito do conhecimento prévio, não restaram evidências de que os homens tenham se comportado mais oportunisticamente do que as mulheres.

Entre as limitações da pesquisa, pode ser salientado que os experimentos apresentam o problema da generalização, já que os indivíduos podem empregar comportamentos diferentes daqueles que teriam no mundo real. A artificialidade do laboratório e o fato de saberem estar sendo observados pode comprometer a veracidade das escolhas, bem como o grau de agressividade na negociação. Há que se considerar que o incentivo na forma de bônus na nota da prova pode não contar com o mesmo apelo que o incentivo monetário das situações reais. Por fim, pode ser questionada a utilização de alunos da graduação em Administração para simular o comportamento dos tomadores de decisão nas empresas.

Apesar dessas limitações, praticamente só a pesquisa experimental permite que o pesquisador conheça os valores de reserva dos envolvidos e, assim, possa analisar as renegociações simuladas e as ocorrências do comportamento oportunista. Por esse motivo, entende-se que seria bem-vinda a réplica da pesquisa desenvolvida neste trabalho, procurando controlar as variáveis relevantes, principalmente as que dizem respeito ao conhecimento prévio e sexo do 
comprador. ${ }^{47}$ Em relação ao conhecimento prévio, sugere-se também que o pesquisador procure identificar se o relacionamento anterior pode ser considerado positivo. Para aprofundar os conhecimentos a respeito da conduta dos participantes nas renegociações, podese até incluir mais um estágio de negociação. Entre os pares que obtiveram o duplo acordo, cabe notar que $48 \%$ dos investidores receberam na renegociação um preço inferior ao pactuado na etapa precedente, mas suficiente para garantir um retorno superior ao proporcionado pelo valor de reserva original. Nessa situação, apesar de o resultado auferido na segunda etapa ainda ser satisfatório, seria interessante descobrir se o preço continuaria caindo se houvesse mais rodadas de negociação.

A replicação desta pesquisa com alunos matriculados em cursos de MBA poderia revelar o comportamento de pessoas hierarquicamente mais próximas das decisões gerenciais nas empresas. Principalmente, seria útil replicar o experimento com alunos de MBA setoriais, já que a proximidade entre os participantes permitiria simular com mais propriedade a postura entre empresas do mesmo setor. Outra sugestão para trabalhos futuros é a réplica da presente pesquisa utilizando-se de recursos monetários como forma de incentivo aos participantes.

Paralelamente à realização das pesquisas experimentais, os analistas da negociação podem também fazer uso de questionários e entrevistas a dirigentes de empresas, para aprofundar as investigações sobre as renegociações e o comportamento oportunista. Por exemplo, com a construção de questionários que utilizem a escala de Likert, ${ }^{48}$ pode-se perguntar se os respondentes concordam ou não com determinadas posturas dos negociadores, bem como qual seria, no entender deles, a forma de pensar dos seus pares. Esse tipo de pesquisa não requer que os dirigentes revelem seus valores de reserva. Contudo, sempre será possível que, por buscarem preservar a auto-imagem e a imagem externa, os dirigentes resistam em admitir que concordariam com posturas oportunistas.

Como as renegociações e os investimentos específicos são obstáculos recorrentes no dia-a-dia dos agentes, sobretudo das organizações econômicas, o estudo das negociações deve dedicar especial atenção a essa temática. Nas renegociações em que o VR se deteriora, a compreensão do comportamento dos agentes pode contribuir para os analistas de negociação e,

\footnotetext{
${ }^{47}$ É importante notar que houve apenas 3 pares em que os participantes se conheciam e o comprador era do sexo feminino.

${ }^{48}$ Variação mais utilizada da escala de classificação somatória (COOPER; SCHINDLER, 2003, p. 201).
} 
principalmente, para os negociadores que necessitem estabelecer acordos com efeitos de média e longa duração. Por fim, aprofundar o entendimento do que ocorre na renegociação auxilia os negociadores a antecipar riscos e, principalmente, a refinar sua decisão de promover investimentos em ativos específicos. 


\section{REFERÊNCIAS}

ANDRADE, Rui Otávio Bernardes de et al. Princípios de negociação. São Paulo: Atlas, 2004.

ARGYRES, Nicholas S.; LIEBESKIND, Júlia Porter. Contractual commitments, bargaining power, and governance inseparability: incorporating history into transaction cost theory. The Academy of Management Review. Briarcliff Manor: Academy of Management, v. 24, n. 1, p. 49-63, 01/1999.

BAZERMAN, Max H.; NEALE, Margaret A. Negociando racionalmente. 2. ed. São Paulo: Atlas, 1998.

BELL, David E et al. Descriptive, normative, and prescriptive interactions in decision making. In: Decision making: descriptive, normative, and prescriptive interactions. New York: Cambridge University Press, 1988.

BIANCHI, Ana Maria; SILVA FILHO, Geraldo A., Economistas de avental branco: uma defesa do método experimental na economia. Revista de Economia Contemporânea. Rio de Janeiro: Universidade Federal do Rio de Janeiro, v. 5, n. 2, p. 129-154, 7-12/2001.

BINMORE, Ken et al. An outside option experiment. The Quarterly Journal of Economics. Cambridge: The MIT Press, v. 104, n. 4, p. 753- 770, 11/1989.

BRAMS, Steven J. Negotiation games. 3rd ed. London: Routledge, 2003.

COHEN, Herb. Você pode negociar qualquer coisa. Rio de Janeiro: Record, 1980.

COOPER, Donald R.; SCHINDLER, Pamela S. Métodos de pesquisa em administração. 7. ed. Porto Alegre: Bookman, 2003.

FARINA, Elizabeth Maria Mercier Querido et al. Competitividade: mercado, estado e organizações. São Paulo: Editora Singular, 1997.

FEHR, Ernst; GÄCHTER, Simon. Fairness and retaliation: the economics of reciprocity. Journal of Economic Perspectives. Nashville: American Economic Association, v. 14, n. 3, p. 159-181, summer/2000.

FIANI, Ronaldo. Teoria dos jogos: para cursos de administração e economia. Rio de Janeiro: Elsevier, 2004.

FISHER, Roger et al. Como chegar ao sim: a negociação de acordos sem concessões. 3. ed. Rio de Janeiro: Imago, 1994. 
GHOSHAL, Sumantra; MORAN, Peter. Bad for practice: a critique of the transaction cost theory. The Academy of Management Review. Briarcliff Manor: Academy of Management, v. 21, n. 1, p. 13-47, 01/1996.

GLAESER, Edward L. et al. Measuring trust. The Quarterly Journal of Economics. Cambridge: The MIT Press, v. 115, n. 3, p. 811-846, 8/2000.

GOULDNER, Alvin W. The norm of reciprocity: a preliminary statement. American Sociological Review. New York: American Sociological Association, v. 25, n. 2, p. 161-178, 04/1960.

GRANOVETTER, Mark. Economic action and social structure: the problem of embeddedness. The American Journal of Sociology. Chicago: The University of Chicago, v. 91, n. 3, p. 481-510, 11/1985.

HACKETT, Steven C., Is relational exchange possible in the absence of reputations and repeated contract? Journal of Law Economics \& Organization. Oxford: Oxford University Press, v. 10, n. 2, p. 360-389, 10/1994.

HART, Oliver; MOORE, John. Incomplete contracts and renegotiation. Econometrica. Evanston: Econometric Society, v. 56, n. 4, p. 755-785, 07/1988.

HILL, Charles W. L. Cooperation, opportunism, and the invisible hand: implications for transaction cost theory. The Academy of Management Review. Briarcliff Manor: Academy of Management, v. 15, n. 3, p. 500-513, 07/1990.

KLEIN, Benjamin. Why hold-ups occur: the self-enforcing range of contractual relationships. Economic Inquiry. Huntington Beach: Western Association International, v. 34, n. 3, p. 444463, 07/1996.

KLEIN, Benjamin et al. Vertical integration, appropriable rents, and the competitive contracting process. Journal of Law \& Economics. Chicago: University of Chicago Press, v. 21, issue 2, p. 297-326, 10/1978.

KREPS, David M. Game theory and economic modelling. New York: Oxford University Press, 1990.

LAX, David A.; SEBENIUS, James K., The manager as negotiator: bargaining for cooperation and competitive gain. New York: Free Press, 1986.

LEWICKI, Roy L. et al. Fundamentos de negociação. Porto Alegre: Bookman, 2002.

MARTINELLI, Dante P. et al. Negociação internacional. São Paulo: Atlas, 2004. 
MELLO, José Carlos Martins F. de. Negociação baseada em estratégia. São Paulo: Atlas, 2003.

MILGROM, Paul R.; ROBERTS John. Economics, organizations, and management. New Jersey: Prentice Hall, 1992.

NALEBUFF Barry J.; BRANDERBURGER Adam M. Co-opetição. Rio de Janeiro: Rocco, 1996.

RAIFFA, Howard. The art and science of negotiation. Cambridge, MA; London: The Belknap of Harvard University Press, 1982.

et al. Negotiation analysis: the science and the art of collaborative decision making.

Cambridge: The Belknap Press of Harvard University Press, 2002.

RUBINSTEIN, Ariel. Perfect equilibrium in a bargaining model. Econometrica. Evanston: Econometric Society, v. 50, n. 1, p. 97-110, 01/1982.

A bargaining model with incomplete information about time preferences. Econometrica. Evanston: Econometric Society, v. 53, n. 5, p. 1151-1172, 09/1985.

; WOLINSKY, Asher. Renegotiation-proof implementation and time preferences. The American Economic Review. Briarcliff Manor: Academy of Management, v. 82, n. 3, p. 600-614, 06/1992.

SEBENIUS, James K. Negotiation analysis: a characterization and review. Management Science. Linthicum: Institute for Operations Research and the Management Sciences, v. 38, n. 1, p. 19-38, 01/1992.

SHELL, Richard G., Negociar é preciso: estratégias de negociação para pessoas de bom senso. 5. ed. São Paulo: Negócio Editora, 2001.

SIMON, Herbert. A. Administrative behavior: a study of decision-making processes in administrative organization. 2nd ed. New York: The Macmillan Company, 1957.

TVERSKY, Amos; KAHNEMAN, Daniel. Can normative and descriptive analysis be reconciled? [S.I.]: Center for Philosophy and Public Policy, 03/1987.

. The Framing of decisions and the psychology of choice. In: ELSTER, Jon (Org), Rational choice. Oxford: Basil Blackwell, 1986.

Conflict resolution: a cognitive perspective. In: Arrow, Kenneth J. et al. (Org), Barriers to conflict resolution. New York: W.W. Norton \& Company, 1995. 
TIROLE, Jean. Procurement and renegotiation. The Journal of Political Economy. Chicago: University of Chicago, v. 94, n. 2, p. 235-259, 04/1986.

Incomplete contracts: where do we stand? Econometrica. Evanston: Econometric Society, v. 67, n. 4, p. 741-781, 07/1999.

VAZSONYI, Andrew, Decision making: normative, descriptive and decision counseling. Managerial and Decision Economics. New York: John Wiley \& Sons, v. 11, n. 5, p. 317$325,12 / 1990$.

WATKINS, Michael, Negociação. Rio de Janeiro: Record, 2004.

WILLIAMSON, Oliver E., The economic institutions of capitalism. New York: The Free Press, 1987.

Opportunism and its critics. Managerial and Decision Economics. New York: John Wiley \& Sons, v. 14, n. 2, p. 97-107, 03-04/1993.

. The mechanisms of governance. New York: Oxford University Press, 1996. 


\section{APÊNDICES}

APÊNDICE 1: INSTRUÇÕES INICIAIS

APÊNDICE 2: INSTRUÇÕES PARA A SEGUNDA RODADA DE NEGOCIAÇÃO APÊNDICE 3: ENVELOPE CONFIDENCIAL

APÊNDICE 4: RESULTADO DA PRIMEIRA RODADA COM ACORDO

APÊNDICE 5: RESULTADO DA PRIMEIRA RODADA SEM ACORDO

APÊNDICE 6: RESULTADO DA SEGUNDA RODADA

APÊNDICE 7: VARIÁVEIS ANALISADAS

APÊNDICE 8: REGRESSÃO LINEAR SIMPLES (P1)

APÊNDICE 9: REGRESS ÃO LINEAR SIMPLES (CP)

APÊNDICE 10: REGRESSÃO LINEAR SIMPLES (SEXCOMP)

APÊNDICE 11: REGRESSÕES LINEARES MÚLTIPLAS 


\title{
APÊNDICE 1: INSTRUÇÕES INICIAIS
}

\author{
EXPERIMENTO DE NEGOCIAÇÃO
}

\section{PRIMEIRA RODADA DE NEGOCIAÇÃO}

O COMPRADOR é dono de uma empresa de brinquedos, localizada na Cidade de Araguari (MG), a $720 \mathrm{Km}$ do Centro Industrial do ABC Paulista (veja o mapa abaixo). Essa empresa utiliza como matéria-prima um (1) lote de plástico todo ano.

- O COMPRADOR tem adquirido o plástico de um produtor estrangeiro;

- Esse produtor estrangeiro está cobrando \$ 85 pelo lote;

- Pode ocorrer oscilação no preço do lote de um ano para outro.

O INVESTIDOR está estudando a possibilidade de construir, em Araguari (MG), uma fábrica de plástico com capacidade para produzir exatamente um (1) lote de plástico por ano.

- Para construir a fábrica, o INVESTIDOR precisa investir uma determinada quantia;

- Essa quantia aplicada no mercado financeiro rende \$45 ao ano;

- O custo de fabricação do lote de plástico é \$ 15 no primeiro ano (Isso significa que precisa vender o lote por mais de $\$ 60$, para superar o ganho que obteria no mercado financeiro);

- Existem compradores alternativos para o lote de plástico. Eles estão localizados no ABC Paulista, e pagam \$ 35 pelo lote (já descontando o frete para o ABC).

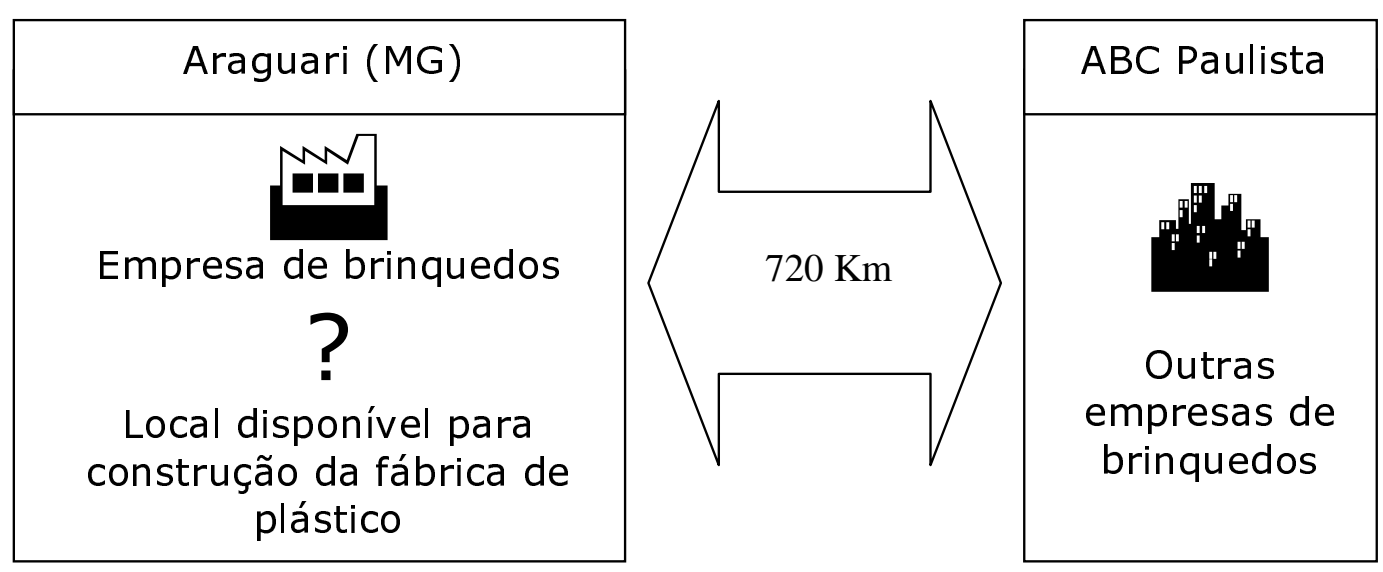

O INVESTIDOR precisa decidir se constrói ou não a fábrica de plástico. Se o INVESTIDOR decidir pela construção da fábrica, o COMPRADOR e o INVESTIDOR devem negociar o preço do lote de plástico para o primeiro ano.

Concluídas as conversações, COMPRADOR e INVESTIDOR devem preencher o formulário RESULTADO DA PRIMEIRA RODADA, informando se houve acordo, e o eventual preço do lote negociado. 
Se o INVESTIDOR optar pela construção da fábrica, ocorrerá uma segunda rodada de negociação. Se não houver a construção da fábrica (isto é, não existindo acordo), o COMPRADOR e o INVESTIDOR estão dispensados da segunda rodada.

Bonificação: Todos os alunos participantes receberão um bônus na prova da disciplina EAD 475 - Modelos de Negociação. Quanto melhor o desempenho do aluno neste experimento, maior será o seu bônus.

\section{IMPORTANTE}

- Tempo disponível para negociação: 15 minutos.

- Decorridos esses 15 minutos, serão entregues os formulários para preenchimento do resultado da negociação. 


\section{APÊNDICE 2: INSTRUÇÕES PARA A SEGUNDA RODADA DE NEGOCIAÇÃo}

\section{EXPERIMENTO DE NEGOCIAÇÃO}

\section{SEGUNDA RODADA DE NEGOCIAÇÃO}

Como o INVESTIDOR optou pela construção da fábrica, ocorre a segunda rodada de negociação, na qual será acordado o preço do lote de plástico para o segundo ano.

- O custo de fabricação do lote de plástico continua $\$ 15$;

- O COMPRADOR receberá uma nova proposta do produtor estrangeiro.

Se as partes NÃO CHEGAREM A UM ACORDO para o preço do lote de plástico, pressupõe-se que as partes utilizarão suas melhores alternativas, conforme abaixo:

- INVESTIDOR: vende o lote de plástico para outras empresas de brinquedo, localizadas no ABC Paulista, por \$35;

- COMPRADOR: adquire plástico do produtor estrangeiro.

Concluídas as conversações, COMPRADOR e INVESTIDOR devem preencher o formulário RESULTADO DA SEGUNDA RODADA, informando se houve acordo, e o eventual preço do lote negociado.

\section{IMPORTANTE}

O COMPRADOR receberá um envelope confidencial contendo o preço de venda do lote de plástico praticado pelo produtor estrangeiro. 


\section{APÊNDICE 3: ENVELOPE CONFIDENCIAL}

\section{EXPERIMENTO DE NEGOCIAÇÃO}

\section{PROPOSTA CONFIDENCIAL}

Conforme já foi descrito nas instruções gerais, a proposta submetida pelo produtor estrangeiro é informada somente ao COMPRADOR. Trata-se de uma informação confidencial, desconhecida pelo INVESTIDOR. Dessa forma, você poderá ou não revelá-la ao INVESTIDOR.

Caso você decida revelar algum valor ao INVESTIDOR, faça isso com o necessário cuidado, a fim de que essa informação não interfira na negociação de outros pares COMPRADORINVESTIDOR.

\section{PROPOSTA DE VENDA:}

O produtor estrangeiro está oferecendo o lote de plástico por \$ 85 .

Como você pode reparar, não houve alteração no preço do lote ofertado pelo produtor estrangeiro. 


\section{APÊNDICE 4: RESULTADO DA PRIMEIRA RODADA COM ACORDO \\ RESULTADO DA PRIMEIRA RODADA}

NOME DO INVESTIDOR:

Idade: __ Sexo: F( ) M( )

Ano de ingresso na faculdade:

Exerce (ou já exerceu) alguma profissão? ( ) Sim ( ) Não

Se afirmativo, qual? (informar profissão atual ou mais recente)

NOME DO COMPRADOR:

Idade: __ Sexo: F( ) M( )

Ano de ingresso na faculdade:

Exerce (ou já exerceu) alguma profissão? ( ) Sim ( ) Não

Se afirmativo, qual? (informar profissão atual ou mais recente)

\section{O INVESTIDOR CONSTRÓI A FÁBRICA? $\quad$ ( X ) SIM （） NÃO}

\section{PREÇO ACORDADO:}

\section{PROPOSTA INICIAL DE COMPRA OU VENDA DO LOTE}

Quem fez a proposta inicial?

( ) COMPRADOR ( ) INVESTIDOR

Qual foi o valor da proposta inicial? 


\section{APÊNDICE 5: RESULTADO DA PRIMEIRA RODADA SEM ACORDO}

\section{RESULTADO DA PRIMEIRA RODADA}

\section{NOME DO INVESTIDOR:}

Idade: ___ Sexo: F( ) M ( )

Ano de ingresso na faculdade:

Exerce (ou já exerceu) alguma profissão? ( ) Sim ( ) Não

Se afirmativo, qual? (informar profissão atual ou mais recente)

NOME DO COMPRADOR:

Idade: ___ Sexo: F( ) M( )

Ano de ingresso na faculdade:

Exerce (ou já exerceu) alguma profissão? ( ) Sim ( ) Não

Se afirmativo, qual? (informar profissão atual ou mais recente)

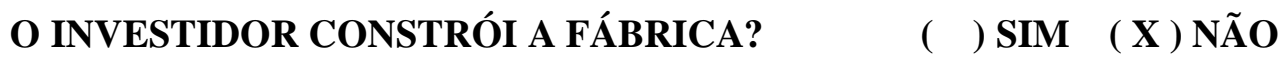

\section{PROPOSTA INICIAL DE COMPRA OU VENDA DO LOTE}

Quem fez a proposta inicial?

$$
\text { ( ) COMPRADOR ( ) INVESTIDOR }
$$

Qual foi o valor da proposta inicial?

\section{IMPASSE NA NEGOCIAÇÃO}

Último preço que o comprador se dispôs a pagar:

Último preço que o investidor se dispôs a vender:

\section{RELACIONAMENTO PRÉVIO DOS PARTICIPANTES}

Já se conheciam antes?

( ) $\operatorname{Sim}$ ( ) Não

Já participaram de algum trabalho ou prova no mesmo grupo?

( ) $\operatorname{Sim}$ ( ) Não

Têm (ou já tiveram) contato em algum outro grupo social (amigos, empresa-júnior, atlética, trabalho, etc)?

( ) $\operatorname{Sim}$ ( ) Não

Já fizeram juntos alguma outra disciplina na Faculdade?

( ) Não ( ) Sim, menos de cinco disciplinas ( ) Sim, cinco ou mais disciplinas 


\title{
APÊNDICE 6: RESULTADO DA SEGUNDA RODADA
}

\author{
RESULTADO DA SEGUNDA RODADA
}

NOME DO INVESTIDOR:

NOME DO COMPRADOR:

HOUVE ACORDO?

( ) SIM ( ) NÃO

PREÇO ACORDADO: (informar somente se houve acordo)

Se não houve acordo de preços, favor informar:

Último preço que o comprador se dispôs a pagar:

Último preço que o investidor se dispôs a vender:

\section{RELACIONAMENTO PRÉVIO DOS PARTICIPANTES}

Já se conheciam antes?

( ) Sim ( ) Não

Já participaram de algum trabalho ou prova no mesmo grupo?

( ) Sim ( ) Não

Têm (ou já tiveram) contato em algum outro grupo social (amigos, empresa-júnior, atlética, $\begin{array}{ll}\text { trabalho, etc)? } & \text { ( ) Sim ( ) Não }\end{array}$ Já fizeram juntos alguma outra disciplina na Faculdade?

( ) Não ( ) Sim, menos de cinco disciplinas ( ) Sim, cinco ou mais disciplinas

\section{INFORMAÇÕES A SEREM PREENCHIDAS PELO INVESTIDOR:}

O comprador lhe informou o preço da proposta do exterior? （） Sim （） Não Se você respondeu afirmativamente, qual foi o valor informado? 


\section{APÊNDICE 7: VARIÁVEIS ANALISADAS}

\section{Variável dependente}

EV - Evolução do preço nas rodadas $\left(\mathrm{P}_{2}-\mathrm{P}_{1}\right)$

\section{Variáveis independentes testadas}

IDCOMP - idade do comprador

SEXCOMP - sexo do comprador $($ masculino $=0 ;$ feminino $=1$ )

INGCOMP - ano de ingresso do comprador na faculdade

PROFCOMP - profissão do comprador (não exerce $=0$; exerce $=1$ )

IDINV - idade do investidor

SEXINV - sexo do investidor $($ masculino $=0 ;$ feminino $=1)$

INGINV - ano de ingresso do investidor na faculdade

PROFINV - profissão do investidor (não exerce $=0$; exerce $=1$ )

PROP - proponente inicial (investidor $=0 ;$ comprador $=1$ )

$\mathrm{CP}$ - conhecimento prévio (não se conheciam $=0$; conheciam-se $=1$ )

DA - disciplinas anteriores (não fizeram outras juntos $=0$; fizeram outras juntos $=1$ ) 


\section{APÊNDICE 8: REGRESSÃO LINEAR SIMPLES (P1)}

Modelo:

$$
\mathrm{EV}=16,55-0,30 * \mathrm{P} 1+\varepsilon
$$

\section{Resultados:}

\begin{tabular}{|c|c|c|c|c|}
\hline \multicolumn{5}{|c|}{$\begin{array}{l}\text { Dependent Variable: EV } \\
\text { Method: Least Squares } \\
\text { Sample: } 175 \\
\text { Included observations: } 75\end{array}$} \\
\hline $\begin{array}{l}\text { Variable } \\
\end{array}$ & Coefficient & Std. Error & $\mathrm{t}$-Statistic & Prob. \\
\hline $\begin{array}{c}\mathrm{C} \\
\mathrm{P} 1 \\
\end{array}$ & $\begin{array}{r}16.54929 \\
-0.302600 \\
\end{array}$ & $\begin{array}{l}16.17992 \\
0.223855 \\
\end{array}$ & $\begin{array}{r}1.022829 \\
-1.351770 \\
\end{array}$ & $\begin{array}{l}0.3098 \\
0.1806 \\
\end{array}$ \\
\hline $\begin{array}{l}\text { R-squared } \\
\text { Adjusted R-squared } \\
\text { S.E. of regression } \\
\text { Sum squared resid } \\
\text { Log likelihood } \\
\text { Durbin-Watson stat }\end{array}$ & $\begin{array}{r}0.024420 \\
0.011056 \\
9.015568 \\
5933.475 \\
-270.3283 \\
1.956602 \\
\end{array}$ & $\begin{array}{l}\text { Mean depe } \\
\text { S.D. depen } \\
\text { Akaike info } \\
\text { Schwarz cr } \\
\text { F-statistic } \\
\text { Prob(F-stat }\end{array}$ & $\begin{array}{l}\text { dent var } \\
\text { ent var } \\
\text { riterion } \\
\text { erion } \\
\text { tic) }\end{array}$ & $\begin{array}{r}-5.276933 \\
9.065823 \\
7.262088 \\
7.323887 \\
1.827283 \\
0.180622 \\
\end{array}$ \\
\hline
\end{tabular}

\section{Conclusão:}

$\operatorname{Prob}($ F-statistic $)=0,180622$

Não há evidências de associação $(\mathrm{P}<0,05)$

Teste dos resíduos $(\varepsilon)$ :

Não foi realizado em virtude da rejeição do modelo 


\section{APÊNDICE 9: REGRESSÃO LINEAR SIMPLES (CP)}

Modelo:

$$
\mathrm{EV}=-4,03-6,67 * \mathrm{CP}+\varepsilon
$$

\section{Resultados:}

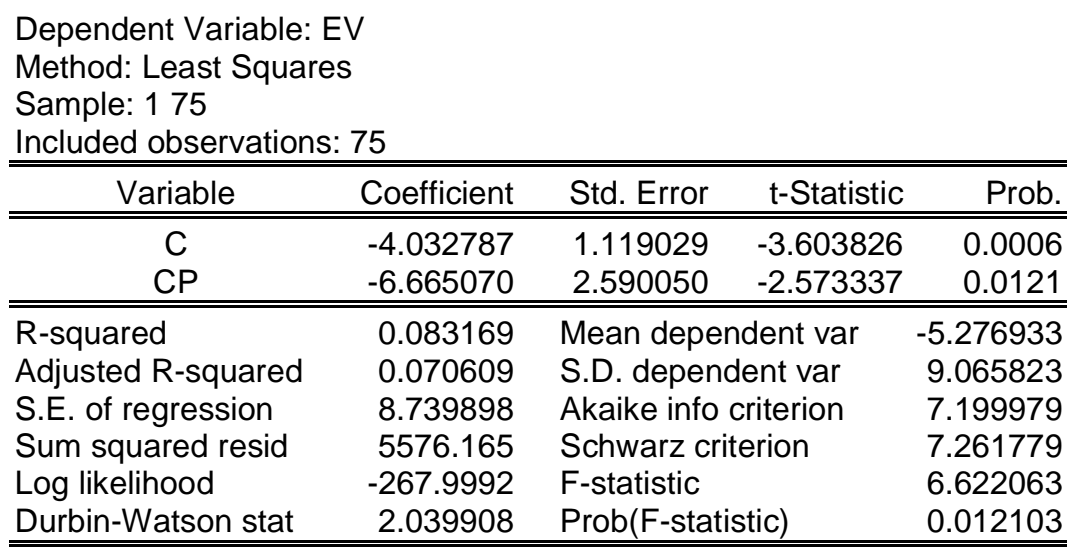

\section{Conclusão:}

$\operatorname{Prob}($ F-statistic $)=0,012103$

Há evidências de associação $(\mathrm{P}<0,05)$

\section{Teste dos resíduos $(\varepsilon)$ :}

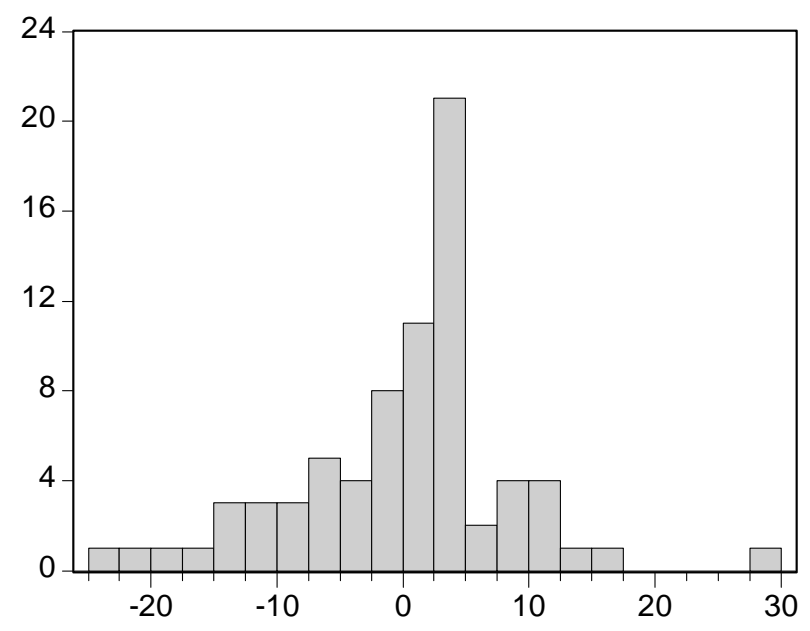

\begin{tabular}{lr|}
\hline \multicolumn{2}{|l|}{ Series: Residuals } \\
Sample 1 75 \\
Observations 75 \\
Mean & $4.26 \mathrm{E}-16$ \\
Median & 1.532787 \\
Maximum & 29.03279 \\
Minimum & -23.96721 \\
Std. Dev. & 8.680644 \\
Skewness & -0.176188 \\
Kurtosis & 4.335403 \\
& \\
Jarque-Bera & 5.960840 \\
Probability & 0.050772 \\
\hline
\end{tabular}




\section{APÊNDICE 10: REGRESSÃO LINEAR SIMPLES (SEXCOMP)}

Modelo:

$$
\mathrm{EV}=-6,33+3,18 * \mathrm{SEXCOMP}+\varepsilon
$$

\section{Resultados:}

Dependent Variable: EV

Method: Least Squares

Sample: 175

Included observations: 75

\begin{tabular}{lrlrr}
\hline \hline \multicolumn{1}{c}{ Variable } & Coefficient & Std. Error & t-Statistic & Prob. \\
\hline \hline C & -6.335400 & 1.272894 & -4.977163 & 0.0000 \\
SEXCOMP & 3.175400 & 2.204717 & 1.440276 & 0.1541 \\
\hline \hline R-squared & 0.027631 & Mean dependent var & -5.276933 \\
Adjusted R-squared & 0.014311 & S.D. dependent var & 9.065823 \\
S.E. of regression & 9.000719 & Akaike info criterion & 7.258791 \\
Sum squared resid & 5913.944 & Schwarz criterion & 7.320590 \\
Log likelihood & -270.2046 & F-statistic & 2.074394 \\
Durbin-Watson stat & 2.019090 & Prob(F-statistic) & 0.154065 \\
\hline \hline
\end{tabular}

\section{Conclusão:}

$\operatorname{Prob}($ F-statistic $)=0,154065$

Não há evidências de associação $(\mathrm{P}<0,05)$

\section{Teste dos resíduos $(\varepsilon)$ :}

Não foi realizado em virtude da rejeição do modelo 


\section{APÊNDICE 11: REGRESSÕES LINEARES MÚLTIPLAS}

\section{Resultados:}

Dependent Variable: EV

Method: Least Squares

Sample: 175

Included observations: 75

\begin{tabular}{lrlrr}
\hline \hline \multicolumn{1}{c}{ Variable } & Coefficient & Std. Error & t-Statistic & Prob. \\
\hline C & -4.951075 & 1.359068 & -3.642993 & 0.0005 \\
SEXCOMP & -6.292389 & 2.602070 & -2.418224 & 0.0181 \\
\multicolumn{1}{c}{2.546161} & 2.150765 & 1.183840 & 0.2404 \\
\hline \hline R-squared & 0.100674 & Mean dependent var & -5.276933 \\
Adjusted R-squared & 0.075693 & S.D. dependent var & 9.065823 \\
S.E. of regression & 8.715964 & Akaike info criterion & 7.207368 \\
Sum squared resid & 5469.698 & Schwarz criterion & 7.300067 \\
Log likelihood & -267.2763 & F-statistic & 4.029979 \\
Durbin-Watson stat & 2.076323 & Prob(F-statistic) & 0.021929 \\
\hline \hline
\end{tabular}

Dependent Variable: EV

Method: Least Squares

Sample: 175

Included observations: 75

\begin{tabular}{crlrr}
\hline \hline \multicolumn{1}{c}{ Variable } & Coefficient & Std. Error & t-Statistic & Prob. \\
\hline C & 20.17458 & 15.59330 & 1.293798 & 0.1999 \\
CP & -6.889718 & 2.569239 & -2.681618 & 0.0091 \\
\multicolumn{1}{c}{ P1 } & -0.335031 & 0.215266 & -1.556357 & 0.1240 \\
\hline \hline R-squared & 0.113009 & Mean dependent var & -5.276933 \\
Adjusted R-squared & 0.088370 & S.D. dependent var & 9.065823 \\
S.E. of regression & 8.655984 & Akaike info criterion & 7.193557 \\
Sum squared resid & 5394.676 & Schwarz criterion & 7.286256 \\
Log likelihood & -266.7584 & F-statistic & 4.586663 \\
Durbin-Watson stat & 1.969093 & Prob(F-statistic) & 0.013338 \\
\hline \hline
\end{tabular}

Dependent Variable: EV

Method: Least Squares

Sample: 175

Included observations: 75

\begin{tabular}{crlrr}
\hline \hline \multicolumn{1}{c}{ Variable } & Coefficient & Std. Error & t-Statistic & Prob. \\
\hline \hline CP & 21.79699 & 15.53198 & 1.403362 & 0.1649 \\
P1 & -6.475221 & 2.569053 & -2.520470 & 0.0140 \\
SEXCOMP & -0.372477 & 0.215481 & -1.728580 & 0.0882 \\
\hline \hline R-squared & 3.003382 & 2.138098 & 1.404698 & 0.1645 \\
Adjusted R-squared & 0.136993 & Mean dependent var & -5.276933 \\
S.E. of regression & 0.100528 & S.D. dependent var & 9.065823 \\
Sum squared resid & 5.598071 & Akaike info criterion & 7.192811 \\
Log likelihood & 5248.805 & Schwarz criterion & 7.316411 \\
Durbin-Watson stat & -265.7304 & F-statistic & 3.756831 \\
\hline \hline
\end{tabular}

\section{Conclusão:}

Não há evidências de associações com SEXCOMP ou P1 ( $<$ < 0,05) 